\title{
Review \\ Research Progress of Plasmonic Nanostructure-Enhanced Photovoltaic Solar Cells
}

\author{
Adnan Ali ${ }^{1}$ (D) Fedwa El-Mellouhi ${ }^{1}$ (D) Anirban Mitra ${ }^{2}$ (D) and Brahim Aïssa $^{1, *(\mathbb{D})}$ \\ 1 Qatar Environment and Energy Research Institute (QEERI), Hamad Bin Khalifa University (HBKU), Qatar \\ Foundation, Doha P.O. Box 34110, Qatar; adali@hbku.edu.qa (A.A.); felmellouhi@hbku.edu.qa (F.E.-M.) \\ 2 Department of Physics, Indian Institute of Technology Roorkee, Roorkee 247667, India; \\ anirban.mitra@ph.iitr.ac.in \\ * Correspondence: brahim.aissa@mpbc.ca or baissa@hbku.edu.qa
}

check for updates

Citation: Ali, A.; El-Mellouhi, F.; Mitra, A.; Aïssa, B. Research Progress of Plasmonic

Nanostructure-Enhanced

Photovoltaic Solar Cells.

Nanomaterials 2022, 12, 788. https:// doi.org/10.3390/nano12050788

Academic Editor: Jacinto Sá

Received: 28 December 2021

Accepted: 11 February 2022

Published: 25 February 2022

Publisher's Note: MDPI stays neutral with regard to jurisdictional claims in published maps and institutional affiliations.

Copyright: () 2022 by the authors Licensee MDPI, Basel, Switzerland. This article is an open access article distributed under the terms and conditions of the Creative Commons Attribution (CC BY) license (https:// creativecommons.org/licenses/by/ $4.0 /)$.

\begin{abstract}
Enhancement of the electromagnetic properties of metallic nanostructures constitute an extensive research field related to plasmonics. The latter term is derived from plasmons, which are quanta corresponding to longitudinal waves that are propagating in matter by the collective motion of electrons. Plasmonics are increasingly finding wide application in sensing, microscopy, optical communications, biophotonics, and light trapping enhancement for solar energy conversion. Although the plasmonics field has relatively a short history of development, it has led to substantial advancement in enhancing the absorption of the solar spectrum and charge carrier separation efficiency. Recently, huge developments have been made in understanding the basic parameters and mechanisms governing the application of plasmonics, including the effects of nanoparticles' size, arrangement, and geometry and how all these factors impact the dielectric field in the surrounding medium of the plasmons. This review article emphasizes recent developments, fundamentals, and fabrication techniques for plasmonic nanostructures while investigating their thermal effects and detailing light-trapping enhancement mechanisms. The mismatch effect of the front and back light grating for optimum light trapping is also discussed. Different arrangements of plasmonic nanostructures in photovoltaics for efficiency enhancement, plasmonics' limitations, and modeling performance are also deeply explored.
\end{abstract}

Keywords: plasmonics; nanostructures; light trapping; lithographic techniques; silicon solar cell; organic solar cell; perovskite solar cell; simulation and modeling

\section{Contents}

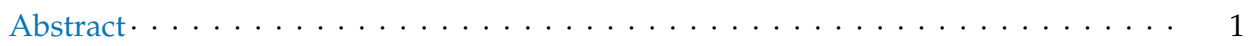

1

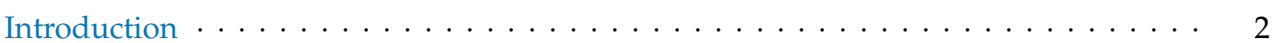

Fundamentals: Physical Properties of Surface Plasmons . . . . . . . . . . . . . . 3

Plasmon Thermal Effects . . . . . . . . . . . . . . . . . . . 5

Plasmonic Nanostructure Top-Down Fabrication Techniques . . . . . . . . . . . . . . 7

4.1 Lithographic Fabrication Techniques $\ldots \ldots \ldots \ldots \ldots \ldots \ldots$

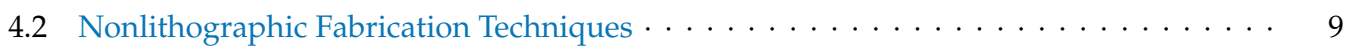

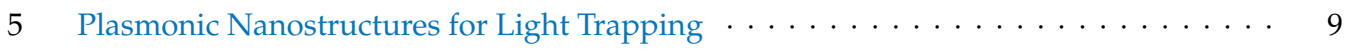

6 Mechanisms of Plasmonic Enhancement Effect . . . . . . . . . . . . . . . . . . 11

7 Nanoparticle Material, Size, and Shape Effects . . . . . . . . . . . . . . . . . 12

7.1 Nanostructures at the Front Surface ～. . . . . . . . . . . . . . . . . . . 13

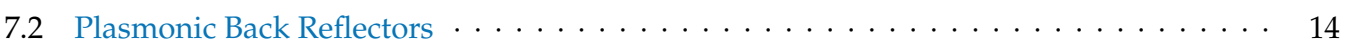

7.3 Mismatch of the Front and Back Light Grating for Optimum Light Trapping . . . . . 16 
Different Arrangements of Plasmonic Nanostructures in PV and Mechanisms . . . . . 18

Modeling the Performance of Plasmonic Solar Cells $\ldots \ldots \ldots \ldots . \ldots \ldots$

9.1 Device Designs Using Propagation of EM Waves $\ldots \ldots \ldots \ldots$

9.2 Plasmonic Systems Based on Light Localization . . . . . . . . . . . . . . . . . . . . . . . . . . 26

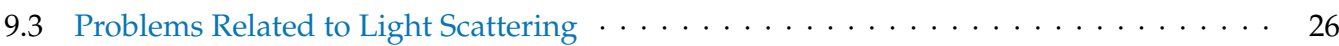

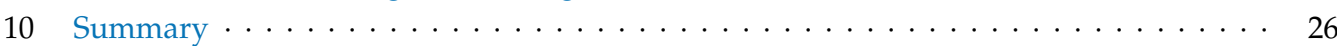

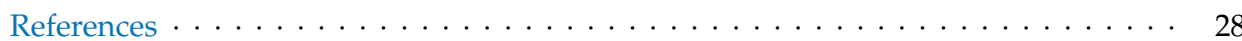

\section{Introduction}

The power of photovoltaics is continuously increasing, going from the current $800 \mathrm{GW}$ worldwide to a predicted 1.3 TW by 2023 [1]. This rapid progress is mainly driven by improvement in solar cell materials and performance, and by the PV module power conversion efficiencies, reduced manufacturing, costs and the realization of levelized electricity costs, which are generally lower now than other energy sources. Silicon solar cells (Al-BSF) have held a market share of 70-90\% over the last decades [2].

A key challenge is to increase the annual production of PV modules by 2040 to 3-4 TW annually [2]. Increasing efficiency is of key importance, as it reduces the required amount of energy-intensive materials such as c-Si and module glass, thereby reducing the energy payback time [3]. The silicon PV industry has many options to drive the efficiency of single-junction silicon solar cells to a practical technical limit of about $27.5 \%$ in laboratory and $26 \%$ in production [4]. The existing global photovoltaic solar cell market is $90 \%$ c-Si based solar cells, while the other $10 \%$ comprises perovskite solar cells (PSCs); dyesensitized solar cells (DSSCs); CdTe, CIGS, $\mu \mathrm{c}-\mathrm{Si}: \mathrm{H}$, and a-Si:H cells; etc. [5-7]. To fulfill global energy demand from photovoltaics, enhancements in light conversion efficiency and cost reduction are the main research targets. Four processes control solar energy harvesting, namely, light absorption, charge separation, charge migration, and charge recombination [8]. To enhance conversion efficiency and decrease cost, a nanophotonic approach for light entrapment has been explored. Different techniques have been applied to enhance light absorption in the active layer [9-12]. Usually, absorption of sunlight can be enhanced by increasing the thickness of the active layer. However, it is possible, because of the nanostructuring/nanopatterning in a solar cell active layer, to entrap light and increase the active layer optical thickness. Optical absorption enhancement provides the freedom to decrease the thickness of active the layer; this decrease has a direct effect on the cost. Furthermore, optical absorption is enhanced via an increase in diffusion length and high open circuit voltage. Nanophotonic structures also contribute to photostability and long-term yielding stability $[13,14]$. Similarly, organic photovoltaic cells (OPVs) have many advantages, such as low cost, light weight, and mechanical flexibility. OPVs suffer mainly from relatively low carrier mobility and small diffusion length [15]. Therefore, to improve the charge carrier diffusion and extraction, a very thin active layer ( $\leq 100 \mathrm{~nm}$ ) is needed to minimize the recombination effect [16]. However, thinning the active layer reduces the light absorption and thus results in lower PCE. Therefore, to enhance light absorption and PCE of OPVs with a thicker active layer, the surface plasmon resonance effect might be utilized by introducing metallic nanoparticles [17-21]. Nanophotonic structures have the advantage of self-cleaning, because dust particles adversely affect solar cell efficiency by accumulating on the photovoltaic cell surface [22-24]. Nanostructures need to be engineered in such a way as to decrease optical losses at the front surface due to light reflection and enhance light transmittance.

For this purpose, in the industry, the main nanostructures used are inverted pyramid or upright structures [23,25-27] or random textures [28-30] with a distinctive typical period size of 3-10 $\mu \mathrm{m}$ applied primarily for c-Si solar cell texturing [31]. It was reported by Kumaravelu et al. [32] that for thin-film solar cells, where the thickness of active layer itself is a few microns/hundreds of nanometers, micron-scale structuring is not advantageous because it requires deep etching and easily creates defects in the active layer. Thus, the most suitable approach for light entrapment in thin film-solar cells is the application of 
nanostructures. Nanostructures for light entrapment are applied mainly as plasmonic metasurfaces and dielectric metasurfaces. Plasmonic metasurfaces are made on the basis of metallic meta-atoms, the optical responses of which are driven by the plasmon resonances supported by metallic particles. For dielectric metasurfaces, the unit structure is constructed with high-refractive index dielectric resonators such as silicon, germanium, or tellurium that can support electric and magnetic dipole responses based on Mie resonances. The responses of plasmonic and dielectric metasurfaces are relevant to the characteristics of unit structure, such as dimensions and materials. One can manipulate the electromagnetic field of light waves scattered by metasurfaces by designing the dimension parameters of each unit structure in the metasurfaces [33]. Chattopadhyay et al. [34] reported that by introducing nanostructures at the surface, light absorption in thin-film solar cells could be improved; this approach was more promising than micron-sized textures at the c-Si solar cell surface. The reason for this improvement is that nanostructure features are less damaging to the substrate, because deep etching is not needed [35]. Furthermore, in subwavelength nanostructures, reflections are curtailed beyond the Yablonovitch conventional limit, and enhanced optical path length can be obtained, as reported by Yu et al. [36]. There are numerous nanostructures with which light can be trapped in thin-film solar cells. The most used approaches for light trapping are plasmonic nanoparticle structures [37,38], random scattering surfaces [28], periodic nanograting [39,40], nanowires [41], and photonic crystal structures [28,42].

Plasmonic nanostructures applied to solar cells have emerged as a growing field of research in the last years, with a huge increase between 2007 and 2021 (with a peak recorded in 2015), as witnessed by the numbers of published works reported in Figure 1. These data were extracted from the Scopus database with the combined "plasmonic" and "solar cell" search terms.

(a)

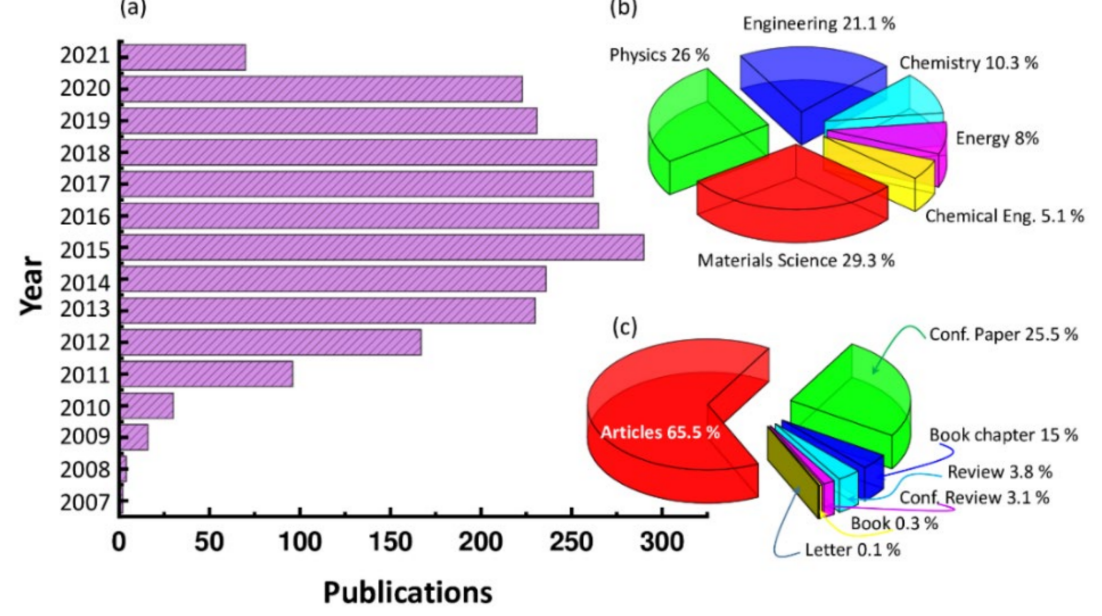

Figure 1. (a) Recent publications referred to herein related to the field of "plasmonics plus solar cell" together with distribution of these publications (b) per field and (c) per type of document. Data were collected from Scopus, an expertly curated abstract and citation database-based information service.

In this review, we summarize up-to-date published work related to plasmonic nanoparticle applications in PV solar cells, both organic and inorganic, and how these applications affect device performance with different nanomaterials, sizes, shapes, combinations, and locations / placement in different layers of the device. It is also reported that the mechanisms through which the device performs change with these parameters.

\section{Fundamentals: Physical Properties of Surface Plasmons}

Surface plasmon resonance (SPR) in solid state physics is known as a collective oscillation of electrons. The SPR phenomenon occurs when electromagnetic (EM) radiation is incident on a noble metal's nanoparticle (NP) surface. This triggers a coherent oscillation 
of the electron cloud at the NP surface and leaves behind positive ions to vacillate like jelly. This happens because of the inherent nature of the alternating EM field of incident radiation. As a result of the coherent oscillation in the alternating field, the electron cloud distributes on the surface and away from nuclei. A restoring force is generated because of Coulombic attraction (see Figure 2). Usually, this phenomenon takes place at the interface of negative- and positive-permittivity materials.

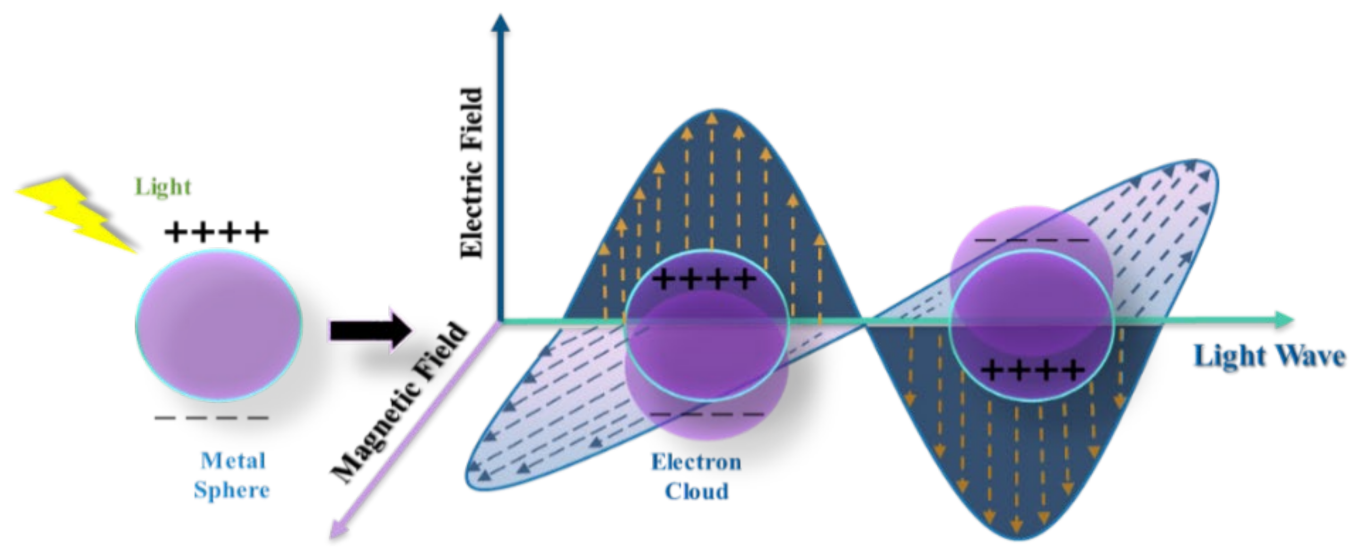

Figure 2. The electrons in a metal can careen like a jelly, pulled back by the attraction of the positive metal ions that they leave behind. Adapted from refs. [43,44].

Localized surface plasmons (LSPs) are the nonpropagating excitations of the conducting electrons coupled with EM field. The curved surface of the spherical nanoparticle applies a restoring force, which produces resonance in the electrons. This is called a localized surface plasmon resonance.

These modes occur because of the scattering issue of the small, subwavelength conductive NPs in the alternating EM field. As a matter of fact, this resonance for gold $(\mathrm{Au})$ and/or silver (Ag) NPs occurs in the visible range of the EM spectrum. Therefore, one might see bright colors of particles in reflected and transmitted light spectroscopy because of the enhanced light absorption and scattering due to the resonance.

There are various localized surface plasmon resonance mechanisms of photoactivity by which metallic nanostructures may intensify semiconductors' photocatalytic behavior [45-47]. Globally, five mechanisms explain exhaustively how metallic SPR enhances semiconductor photoactivity: (i) hot electron injection (or direct electron transfer [48,49]); (ii) local EM field enhancement (or light concentration [50]); (iii) dipole-dipole coupling enabling resonant energy transfer (or plasmon-induced resonant energy transfer [51]); (iv) the plasmonic heating effect [52]; and (v) light scattering [53]. These master processes are summarized schematically in Figure 3. 


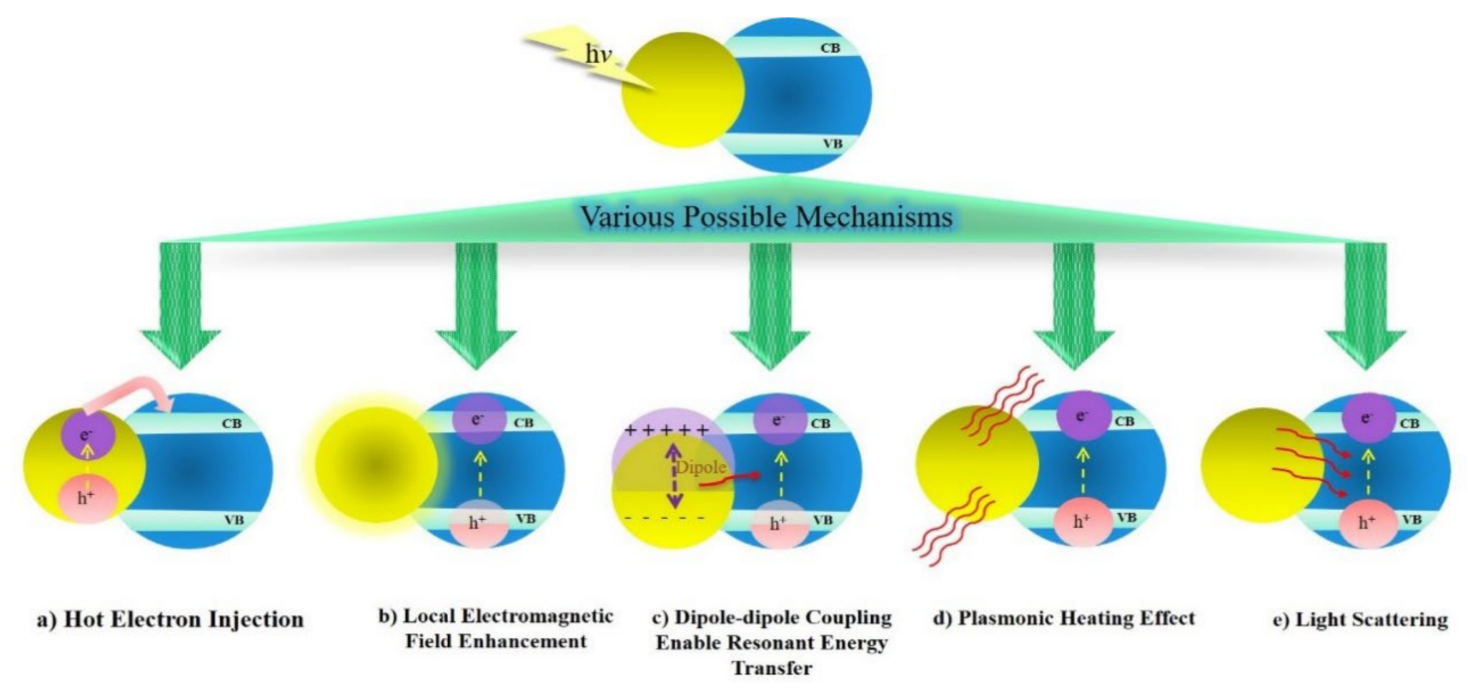

Figure 3. Mechanisms of LSPR photoactivity in semiconductors [54]. Adapted from ref. [54].

\section{Plasmon Thermal Effects}

The oscillation of the electron cloud over metallic NPs during SPR may greatly increase the surface temperature. This effect has been formulated as "plasmonic heating" and is depicted step by step in Figure 4 [55]. In sum, electrons undergo energy loss due to electrical inherent resistance. Defects in the crystal lattice structure, which are often present in nanoparticles, induce additional resistance. Vibrational energy is hence induced because of the energy lost by the electrons in the crystal lattice. This leads to a temperature increase. This increase in temperature can be very dramatic, e.g., several hundred degrees Celsius or up to the melting point of the material. This is most likely to happen when photons with a wavelength corresponding to the LSPR interact with the metal NPs [55-57].

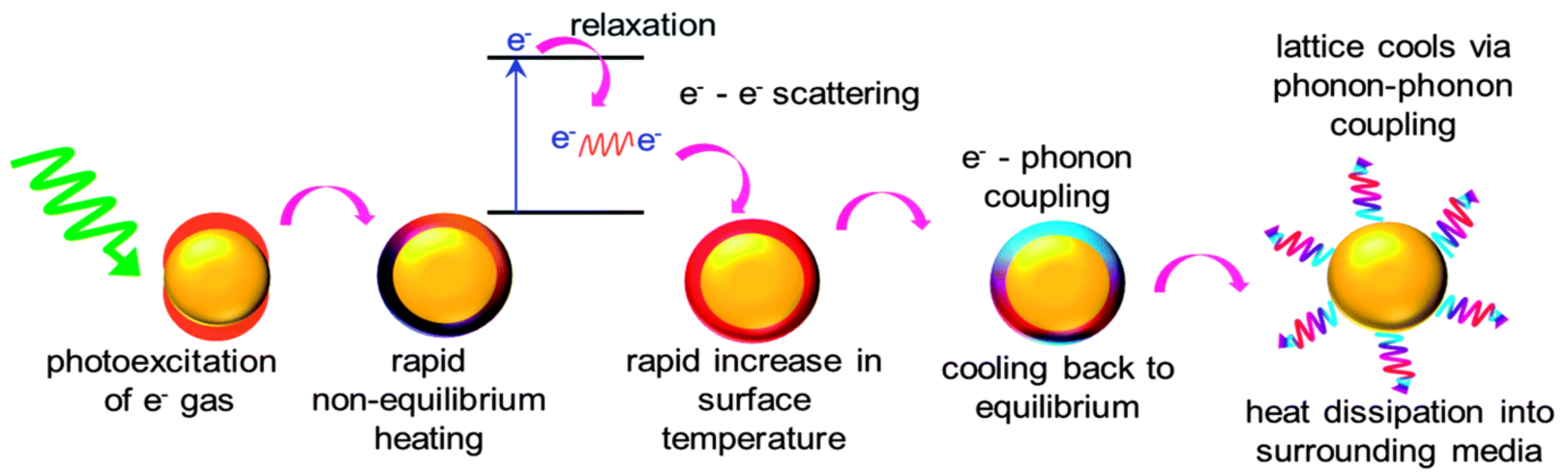

Figure 4. Description of photothermal light to heat conversion by plasmonic nanostructures [55]. Reprinted with permission from Ref. [55], Copyright 2014, The Royal Society of Chemistry.

Lalisse et al. [58] calculated the potential for plasmonic heating of various metal nanoparticles [58]. In the $\mathrm{UV}$-visible region, plasmonic resonance for $\mathrm{Au}, \mathrm{Ag}$, and $\mathrm{Cu}$ occurred around 520, 360, and 300-550 nm, respectively. Of these metals, Au was expected to have the lowest ability to generate heat. However, these calculations were for pure metal nanoparticles. Both silver and copper oxidize rapidly in air, which considerably lowers their applicability. Gold, on the other hand, remains inert to oxidation even at nanoscale size, and hence, its plasmonic heating capacity has attracted additional interest. The other two studied materials were $\mathrm{TiN}$ and $\mathrm{ZrN}$, and both exhibited true potential for plasmonic heating $[59,60]$.

Because of the optical absorption associated with plasmonics resonance, heat is generated from metallic nanoparticles (i.e., through the conversion of EM field's energy by 
resonant light illumination). This heat-generation process is activated by optical absorption and involves photon energy absorption as well as heat transfer from the nanostructures to the surrounding medium.

Wu et al. [61] showed that plasmonic nanostructures improved optical absorption. In addition, the group studied the thermal effects that took place and the associated heat transfer between nanostructures.

Plasmonic nanostructures' dimensions and composition can explain the local and overall heat generation mechanisms. Furthermore the shape of plasmonic nanostructures plays a key role in distributing the temperature over the volume (or surface) and the overall temperature efficiency $[62,63]$.

The groups of Willets [64], Mayer [65] and Zeng [66] reported that the LSP phenomenon may be strongly supported by metallic NPs showing higher numbers of free electrons (such as $\mathrm{Au}$ and $\mathrm{Ag}$ ), as they can interact more efficiently with light and thereby produce collective oscillations at the surface. Furthermore, plasmon decay could occur radiatively through re-emitted photons [67] or nonradiatively via electron-electron and electron-phonon collisions. This conversion of energy produces heat $[68,69]$. This produced heat dissipates, and the local temperature rises in the surrounding area (see Figure 5a). Various parameters affect the heating efficiency, including light intensity, wavelength, light polarization, and especially plasmonic nanostructure geometry [65]. This increase in temperature is critical and needs to be measured accurately, as it must be accounted for when designing photothermal devices.

The techniques employed for measuring this temperature increase include scanning thermal microscopy [65], quadric-wave shearing interferometry [68], surface-enhanced Raman scattering [70], resistance measurements [71], thermographic phosphors [57], refractive index variations, infrared radiation, $\mathrm{X}$-ray absorption spectroscopy, and microwave spectroscopy of nanodiamonds. In fact, it is rather easy to trigger a temperature increase temperature in Au NPs, for example, just by appropriately shining light on it. However, one challenge is how to control this increase quantitatively and accurately. Indeed, it is not straightforward to probe temperature at micro- and/or nanoscales. After the success of thermoplasmonics, probing temperature at the nanoscale was achieved by scanning thermal microscopy (SThM). In the SThM method, a nanometric thermocouple is put at the top of an STM tip to scan the sample. However, this technique is aggressive and not always appropriate. Therefore, fluorescence measurements techniques for plasmonics temperature microscopy have been introduced [72]. The idea behind these techniques is to use the correlation between fluorescence and temperature. In fact, most fluorescence properties are governed by temperature, including intensity, spectrum, lifetime of the excited states, and polarization anisotropy. Therefore, resonance is likely to scatter fluorescent molecules at the locality of metallic nanoparticles. Thus, the mapping of fluorescence reflects that of the temperature of the surface. Figure 5b,c display a typical example of temperature measurement performed on Au NPs by a using a label-free microscopy technique, which uses a quantitative wavefront sensing principle $[73,74]$. Scanning electrochemical microscopy (SECM) [75] is another photothermal measurement method, in which the increase in substrate temperature is measured after it takes place through light irradiating plasmonics. Using plasmonics metal NPs with an electroactive nature, particle-solution interfaces facilitate heterogeneous reactions and thereby allow electron transfer [76]. The photothermal effects can affect the process, increase the rate of mass transport of the redox molecules, and produce an equilibrium potential shift in the nanoparticle electrode. For measuring these effects, SECM can be used efficiently (see Figure 5e,f) [76]. 

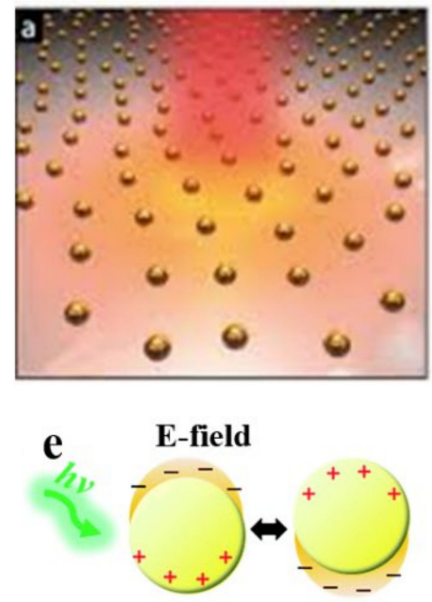

Plasmon Excitation

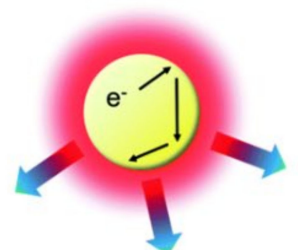

Heat Generation and dissipation

\section{f}
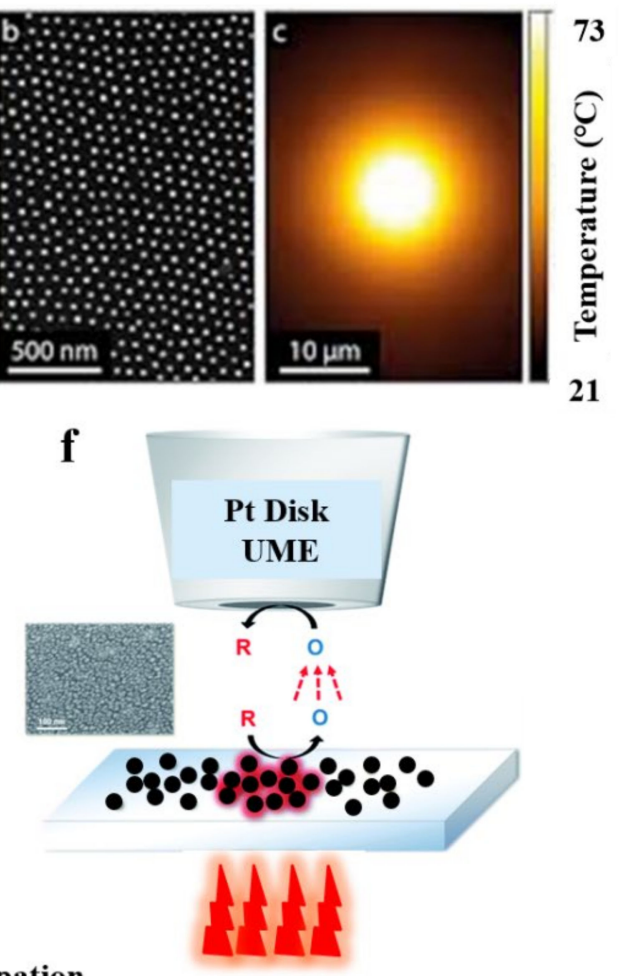

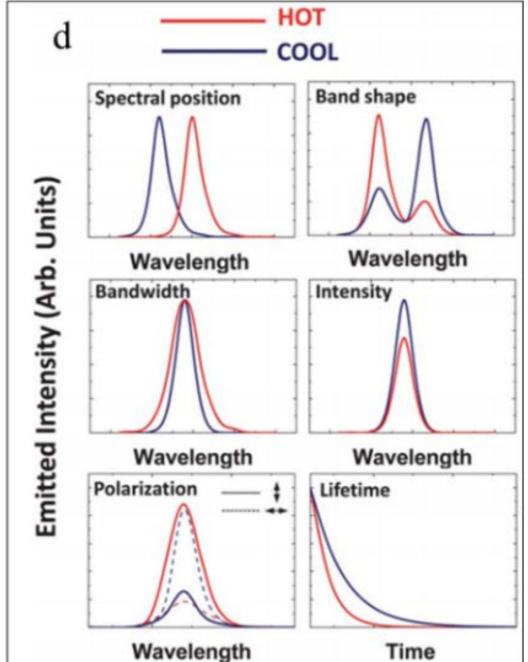

Wavelength

Time

Figure 5. (a) Representation of glass decorated with gold nanoparticles. (b) SEM analysis of gold nanoparticles. (c) Gold nanoparticles after illumination temperature profile [77]. Reprinted with permission from [77], Copyright 2018, EDP Sciences. (d) Possible effects due to temperature increase are schematically represented. Effects due to temperature increase are depicted as red lines. (e) Presentation of (top) excited surface plasmons and (bottom) the resulting plasmonic nanoparticle surface temperature increase. (f) SECM setup with Au nanoparticles on a substrate, schematically depicted with an SEM image [75]. Reprinted with permission from [75], 2018, The Royal Society of Chemistry.

\section{Plasmonic Nanostructure Top-Down Fabrication Techniques}

To make use of plasmonic coupling effects for field enhancement, very accurate control over the dimensions of metallic nanoparticle arrays/structures is required. For local field enhancement, the common approach is to use metallic nanoparticle colloidal aggregates [78], and to benefit from the resonant LSP mode, tailoring the EM field and the reproducibility of the different plasmonic nanostructures to get the same output is required, since randomly oriented aggregates/nanoparticles have demonstrated limited efficiency. To this end, different fabrication techniques have been explored and are summarized in Figure 6. Currently, due to the huge advancement in nanofabrication technologies, the control over plasmonic nanostructures at the nanometer scale is very precise and accurate. 


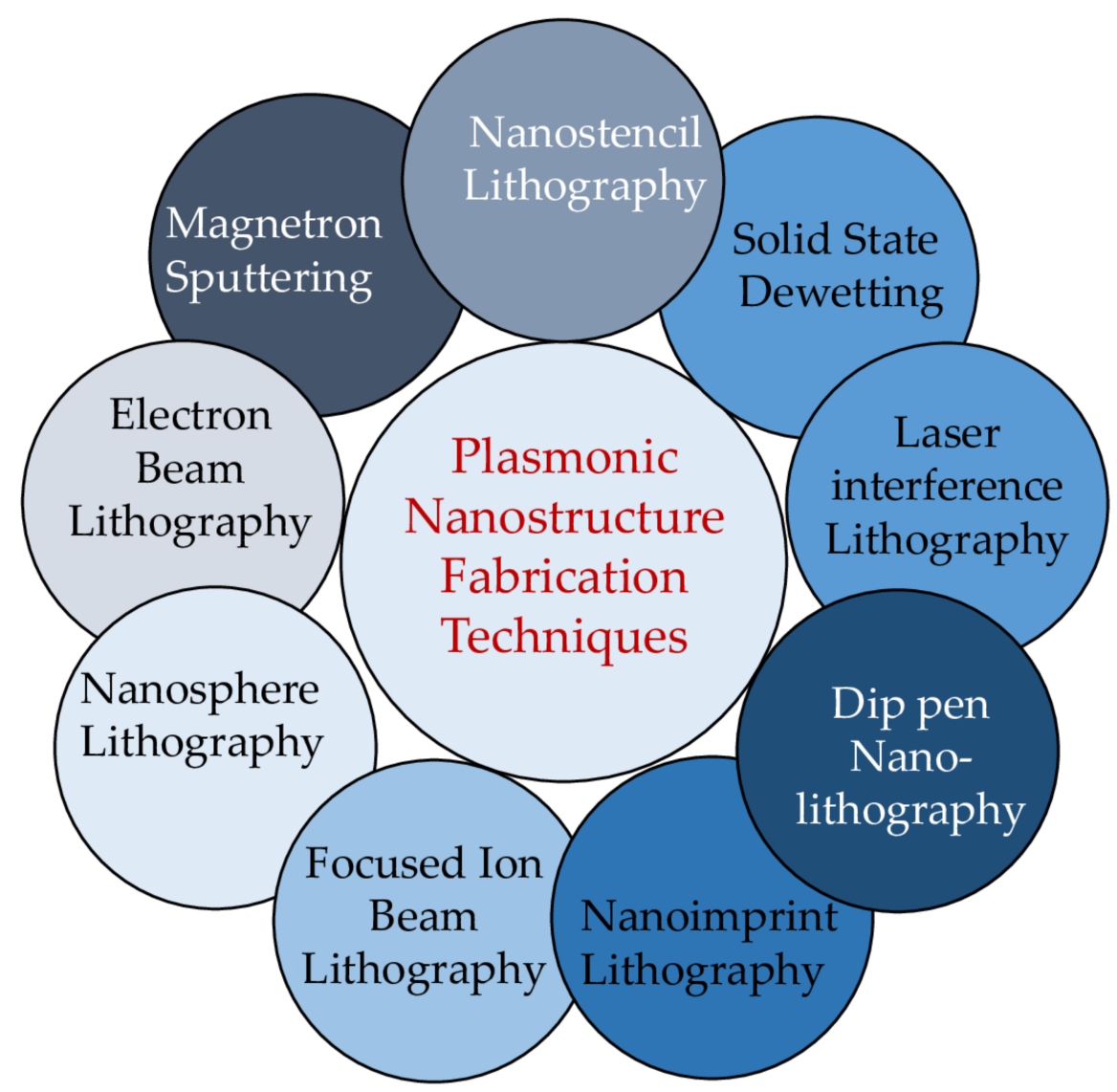

Figure 6. Plasmonics nanostructure top-down fabrication techniques.

\subsection{Lithographic Fabrication Techniques}

The main tool for transferring patterns from substrate to substrate is lithography. Commonly used lithographic fabrication techniques for fabricating plasmonic nanostructures are electron beam evaporation (EBL) $[79,80]$, focused ion beam (FIB), nanosphere lithography (NSL), laser interface lithography, stencil lithography, stamping or nanoimprint lithography (NIL), and dip-pen nanolithography (DPN), as shown in Figure 6. To achieve patterns with features smaller than $100 \mathrm{~nm}$ and subwavelength periodicities, EBL would be the appropriate choice. EBL can realize patterns as small as $\sim 10 \mathrm{~nm}$ with high precision and reproducibility. EBL and lift-off processes are used together. The EBL process has been used successfully to fabricate plasmonic nanostructures including nanopyramids, nanogratings, nanocylinders, and nanorings [79-82].

Another convenient technique is FIB lithography. It is used mainly in optically thick metal films to fabricate nanohole array and slot structures. Khan et al. [83] studied nanohole arrays fabricated in metal film and involving Fano resonances (i.e., resonant scattering that results in an asymmetric line shape) propagating SPPs and LSPPs successfully. They achieved nanoscale features with 4:1 aspect ratio accuracy in a 30-60 nm-thick metal of Au with the FIB milling technique using He/FIB milling.

NSL is another vigorous and inexpensive fabrication technique. It is employed to fabricate ordered 3D nanostructures on a large area, offering a high degree of freedom over the tuning of the nanostructures' geometry, periodicity, and material. Using this lithographic technique, nanometer-scale 3D nanostructures with controlled periods, height/hole depths, and inner/outer diameters and pitches. NSL has been successfully used for nanotowers (solid/hollow) and nanorings/nanodiscs fabricated on different substrates [84-86].

Laser interference lithography (LIL) is another fabrication tool technique and is maskless. The pattern is recorded on a photoresist material by the incident laser beam's interfer- 
ence. Unlike EBL, LIL can efficiently fabricate 2D patterns on a large surface area. Different structures can also be achieved by playing with the laser operating parameters $[87,88]$.

Stencil lithography $[89,90]$ is a resistless technique that employs a shadow mask to achieve micro- and nanometer-scale surface structuring. A stencil is clamped on the substrate, and material is deposited in an evaporating chamber through the stencil's apertures. This technique can also be used for implantation and etching. Two main types of stencil lithography are used based on the material's properties: (i) rigid mask stencil lithography, which uses $\mathrm{Si}$ and $\mathrm{SiN}_{\mathrm{x}}$ masks, and (ii) flexible mask stencil lithography, which employs flexible masks such as polyimide films, PDMS membranes, and photoresist layers [91,92]. Stencil lithography is also categorized based on the motion involved. Dynamic stencil lithography involves motion of the stencil relative to the substrate during the deposition or in between the deposition steps and allows micro-/nanopatterns, multilayers, and different materials for in situ fabrication. Static stencil, as indicated by its name, involves a static substrate and stencil $[89,90,93]$.

Stamping, or nanoimprint lithography (NIL) [94], is another technique for large-area nanostructuring that offers high throughput with high precision and reproducibility. Unlike lithographic techniques using light diffraction or beam scattering, in NIL, a resist is directly deformed mechanically, and this faculty allows fabricating high-resolution features (even at the subwavelength scale). NIL is a very promising technique for large-scale plasmonic structure integration and can be easily extended to complex structures $[95,96]$.

Among the direct-write developed techniques, dip-pen nanolithography (DPN) [97] is a very powerful nanolithographic process like NIL. Instead of stamping, DPN uses a nanoprobe to pattern different surfaces with a resolution down to $15 \mathrm{~nm}$. DPN can be used either in soft materials (polymers, small organic molecules, proteins, DNA) or hard materials (metal oxide NPs, semiconductors, sol-gels) [98-101].

\subsection{Nonlithographic Fabrication Techniques}

For plasmonic nanostructures, the most used nonlithographic fabrication techniques are solid state dewetting (SSD) and magnetron sputtering, as shown in Figure 6. Solid state dewetting [102] (SSD) is a technique in which a thin film on a substrate disintegrates and forms into separated objects, such as droplets, stripes, and pillars. Depending on process parameters (temperature, time, etc.), random and ordered patterns can be obtained by using either a topographically controlled substrate or a substrate with a controlled surface tension $[103,104]$. Ordered particles arrays and complex patterns can also be achieved by SSD using prepatterning of the films $[105,106]$.

The template-assisted magnetron sputtering technique can be used to fabricate plasmonic nanostructures. Qin et al. [107] used magnetron sputtering to deposit a metallic thin film on a nanocup template with well-separated and well-defined features. By varying DC magnetron sputtering deposition time, different shell thickness were obtained. This technique was used to tune the plasmonic resonance. Similarly, it can be used for different nanostructured templates such nanoholes [108] and nanostructures arrays [109] as well as for SERS application [110].

\section{Plasmonic Nanostructures for Light Trapping}

Solanki [111] reported that the energy from the sun reaches the earth surface contains $48 \%$ visible, $43 \%$ infrared, and $7.5 \%$ ultraviolet radiation. Therefore, to harvest solar energy, both regions of the solar spectrum should be targeted. To absorb solar radiation at large with a photovoltaic device, the front and back layers should be designed accordingly. The front surface should be designed to enhance the light transmission into the device, while the surface of the back layer (i.e., facing inward) should be designed to reduce this transmission.

The performance of the thin-film solar cell is typically limited by the low light absorption coefficient and thickness of the absorption layer. Therefore, enhancing the light absorption and its conversion efficiency into electrical current may significantly reduce the cost of production of PV energy. Key sets of methodologies have been developed in order 
to achieve this goal, including the use of nanostructures, such as gradual refractive index matching, localized plasmon resonances, surface plasmon polariton modes, and coupling incident light into guided modes [112].

Using plasmonic nanostructures for photocurrent enhancement in solar cells has some technical barriers that are important to consider, such as (i) parasitic absorption, i.e., photocarrier loss, which produces heat via nonradiative channels as reported by Santbergen et al. [113], Gee et at. [114], and Palanchoke et al. [30]. This can be controlled to some extent by manipulating the metallic nanostructures' size, shape, and patterning. (ii) Xue et al. [115] and Du et al. [116] reported that plasmonic nanostructures incorporated in the absorption layer can act as recombination centers for carriers. This can reduce short circuit current and open circuit voltage [117]. This can be overcome by introducing a thin dielectric casing around the plasmonic nanostructures. (iii) Materials such as $\mathrm{Au}$ and $\mathrm{Ag}$ plasmonics metallic nanoparticles can be costly. Plasmonic nanostructures can broaden the absorption spectral regime in the photovoltaic material. On the other hand, where absorption cannot be enhanced, plasmonic nanostructures can affect the potential of the system.

Numerous nanophotonic structures, including nanocones [24,118-120] (Figure 7A), Si-nanorods [121-123] (Figure 7B(a-d)), nanospheres [124-126] (Figure 7C(a,b)), nanopillars and nanowells [24,124-126] (Figure 7D(a-c)), nanocuboids (Figure 7E(a,b)), nanopyramids [9,26,27,127-131] (Figure 7F(a,b)), nanowells [125,127,128] (Figure 7G(a,b)), and nanopillar (Figure $7 \mathrm{H}(\mathrm{a}, \mathrm{b})$ ) have been extensively studied for improving the efficiency of solar cells. Dielectric, metallic, and absorber layers [132-135] can be applied as photonic nanostructures. Nanostructures can be incorporated in the solar cell in three different scenarios, as summarized in Figure 8: (1) at the front surface, (2) at the back surface, or (3) embedded into the active absorber layer.

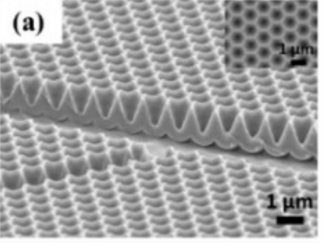

(A)

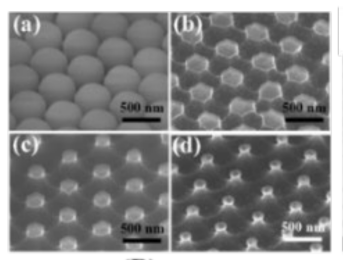

(B)

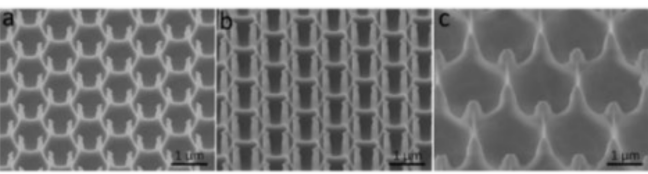

(D)

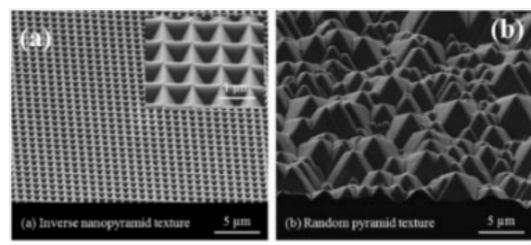

(F)

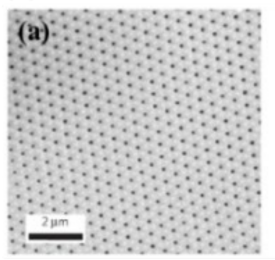

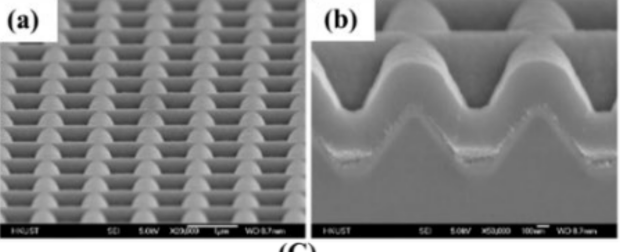

(C)
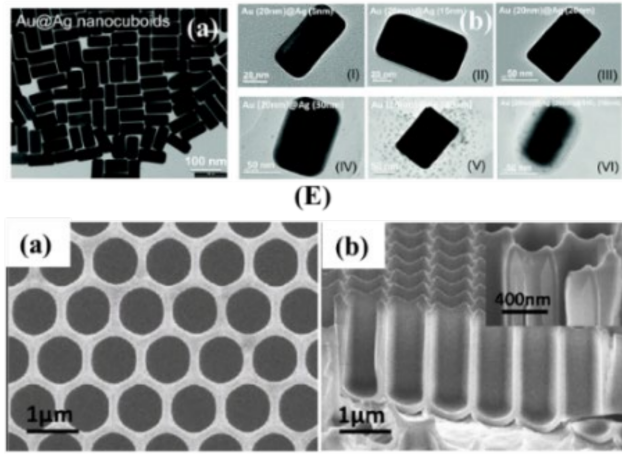

(G)

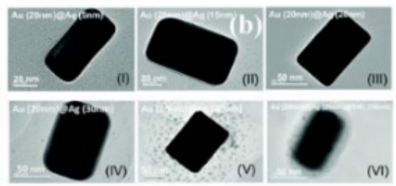

(E)

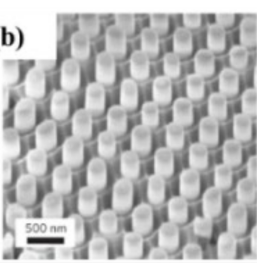

(H)

Figure 7. (A). (a) SEM of Au nanocone-coated template with $1 \mu \mathrm{m}$ pitch and $1 \mu \mathrm{m}$ depth (reprinted 
with permission from [24], 2012, John Wiley and Sons). (B) SEM of a $500 \mathrm{~nm}$ polystyrene nanosphere monolayer and Si nanorod array. (C) SEM micrograph ( $75^{\circ}$ angle) of an ultrathin a-Si/c-Si tandem solar cell on the top surface and at the cross-section (reprinted with permission from [24], 2012, Elsevier). (D) SEM view $\left(60^{\circ}\right.$ angle) of nanopillar structures with different pitches and heights $(\mathbf{a}, \mathbf{b})$. Cross-sectional view SEM of integrated nanopillar/nanowell structures. (Reprinted with permission from [124], 2009, Springer Nature). (E). (a) TEM images of Au@Ag NCs and individual Au@Ag NCs with different Ag shell thicknesses along with an individual Au@Ag@SiO2 NC (reprinted with permission from [127], 2010, American Chemical Society). (F). SEM of surface textures showing 2D grating of an inverse nanopyramid pattern and the industry standard random pyramid texture (reprinted with permission from [128], 2012, American Chemical Society). (G). (a) Top view and crosssectional view SEM of the nanowell sample. (H). (a) SEM of an as-made anodic alumina membrane (AAM) with perfectly ordered pores along with a CdS nanopillar array after partial etching of the AAM (reprinted with permission from [124], 2009, Springer Nature).
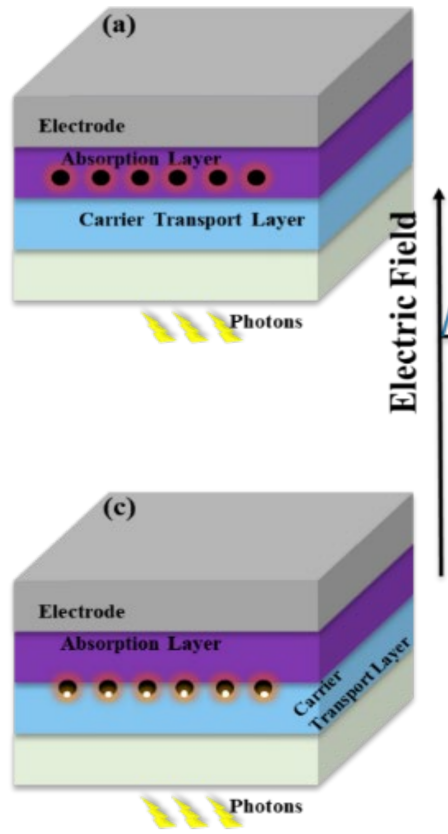

(b)

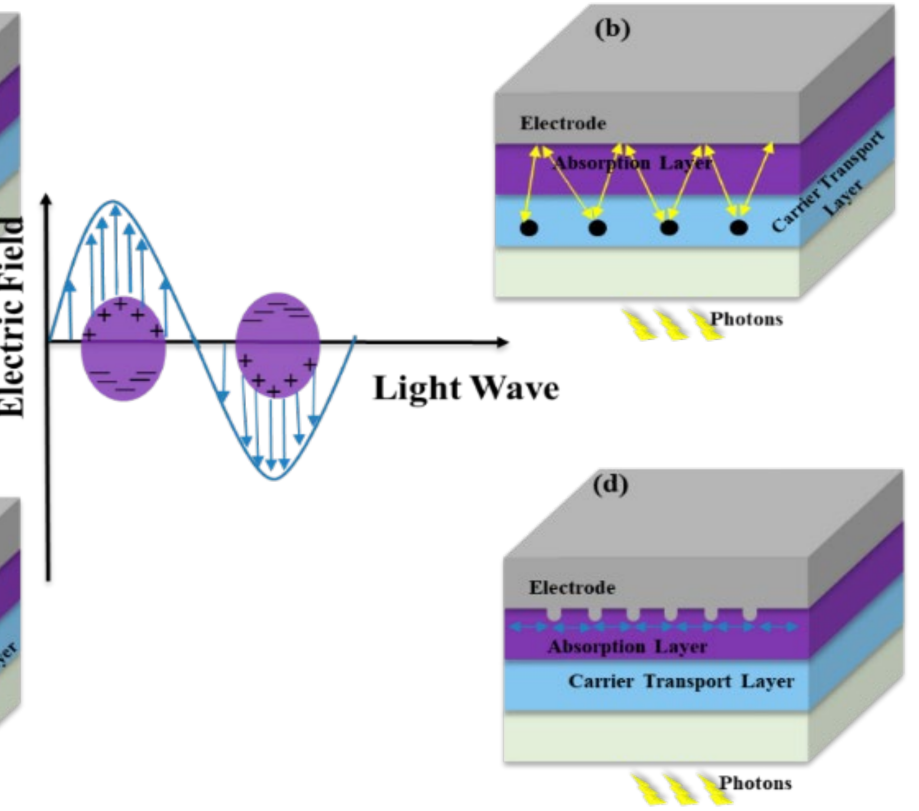

Figure 8. The graph in the middle explains the LSP mechanism in metallic NPs. Structural design of solar cells with plasmonic metallic nanoparticles. (a) LSPR enhancement by embedding nanoparticles in the absorption layer; (b) embedding nanoparticles for trapping light via the forward scattering effect in the charge carrier transport layer (CTL); (c) nanoparticles in the CTL that induced the enhancement of the electromagnetic field in the photoactive layer via the LSPR effect; (d) light trapping by the excitation of surface plasmon polaritons (SPPs) at the metal-semiconductor interface (nanostructured metal films placed on the back surface of a solar cell).

\section{Mechanisms of Plasmonic Enhancement Effect}

In solar cells, light trapping can be enhanced by incorporating metallic nanoparticles, in which electrons can be excited at the interface of the metal and dielectric layers. An EM field then amplifies in the active layer under the SPR effect (see Figure 8). Mie theory explains this EM field amplification [136,137].

Various SPR mechanisms can be used to enhance plasmonics effects such as the nearfield localized effect, the far-field scattering effect, waveguide mode, and plasmon-cavity mode [138-142]. By the far-field scattering effect, optical absorption enhancement can be obtained. This occurs because the incident photons' optical path increases, and the reflection decreases. On the other hand, because of near-field SPR effect, absorption is enhanced. It is known that metallic nanostructures can efficiently limit the EM at the metal-dielectric interface and thereby intensify the SPR effect [143]. 
Many groups have demonstrated $[144,145]$ that in metal nanoparticles, surface plasmons excite LSP, while at the interface of metals and semiconductors, they propagate SPPs (see Figure 8). Metallic nanoparticles can also be implanted into the active layer as subwavelength optical antennas. Through this configuration, the plasmonic near field can be coupled to enhance the light absorption in the surrounding media (Figure 8a) $[146,147]$.

\section{Nanoparticle Material, Size, and Shape Effects}

For the case of plasmonics-based devices, key factors to investigate are related to the scattering and coupling effects $[138,148-150]$ and revolve mainly around surface nanoparticles' material, geometry, size, and distance from the active layer, as well as the medium's refractive index, as depicted in Figure 9A-C. Pillai et al. [150] investigated how the normalized scattering cross-section (SCS) and sphere-shaped particles interacted in two different media, air and silicon. In the latter, because of plasmonics resonance, a clear redshift occurred (comparatively to air), in addition to a clear increase in the light trapping observed in the red and near-IR regions generated through the resonance peaks' redshift and broadening [150].

The particle shape has a strong effect on the scattering efficiency, and it has been reported that with particle size of $\sim 100 \mathrm{~nm}$, a relatively high scattering efficiency can be achieved. Catchpole et al. [148] reported that cylindrical and hemispherical particles could contribute more to enhancing light absorption than spherical particles. In hemisphere geometries, the average spacing to the substrate is smaller than in sphere geometries, leading to effectual coupling of the scattered light and semiconductor substrates.

The plasmonics resonance peak is consistently related to a high light enhancement effect. However, it may be altered by the refractive index value of the adjacent material. For instance, for Ag and Au nanoparticles, plasmonics resonance appears at 350 and $480 \mathrm{~nm}$, respectively. It redshifts to the 500-1500 $\mathrm{nm}$ range when these NPs are deposited onto $\mathrm{SiO}_{2}, \mathrm{Si}_{3} \mathrm{~N}_{4}$, or $\mathrm{Si}$ [151-153]. As the distance between the nanoparticles and the absorbing layer increases, the light scattered into the absorbing layer decreases [148]. A dielectric layer can be used to prevent carrier recombination, which occurs at the metal surface. Indeed, compared with $\mathrm{Au}, \mathrm{Ag}$ nanoparticles improve the light absorption [154], as shown in Figure 9D,E (and Ag is even cheaper than $\mathrm{Au}$ ). On the other hand, Al nanoparticles have increased photon absorption by $28.7 \%$ when deposited at the front side of $\mathrm{Si}$ wafers, which is much a much higher increase than those reported for Au and Ag [155]. When coupling Al nanoparticles with SiNx antireflection coating, a huge enhancement of $42.5 \%$ in the photon absorption was achieved [156], paving thus the way for a cost-effective and highly efficient combination. Uhrenfeldt et al. [156] demonstrated that by depositing Al nanoparticle periodic arrays at the front of a thin Si film, an enhancement in the photogenerated current was obtained with respect to the reference cell. 


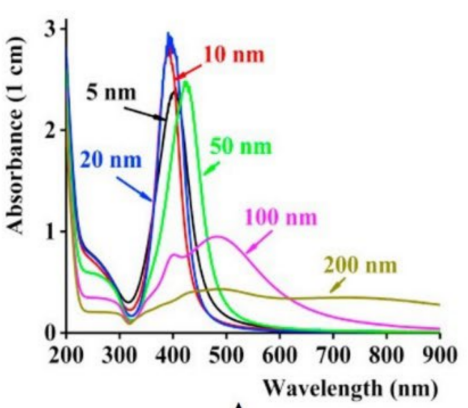

A

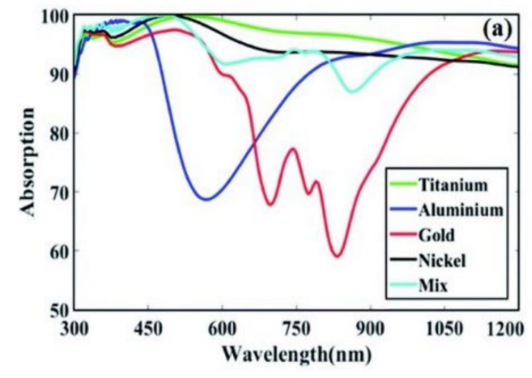

D
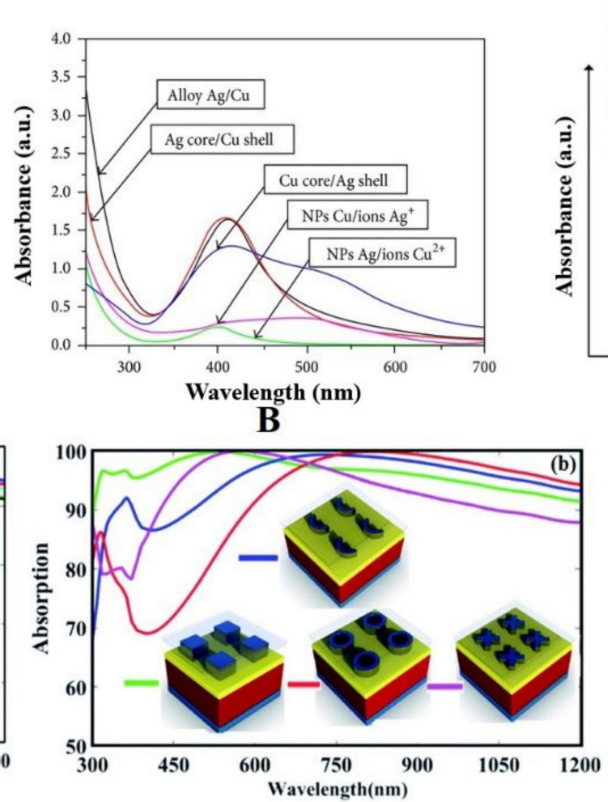
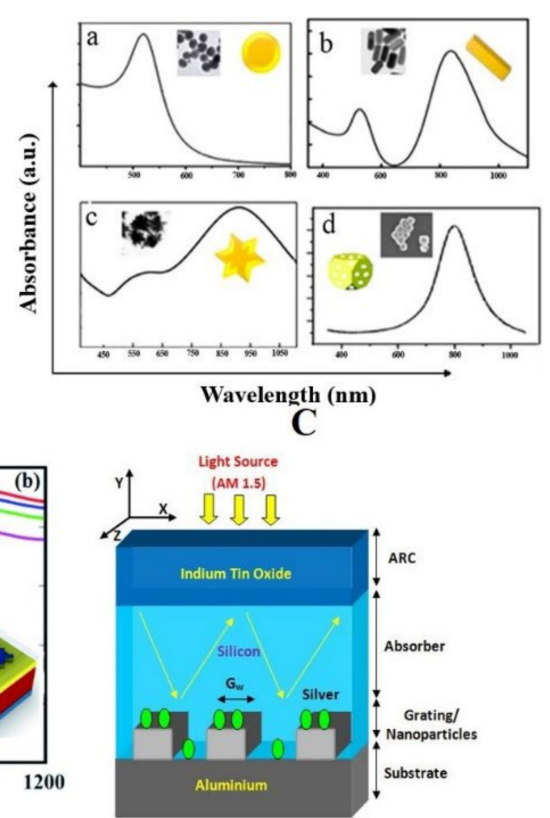

$\mathbf{E}$

Figure 9. (A). Absorbance spectra of different sizes of Ag NPs [157]. (B). Absorbance spectra of bimetallic $(\mathrm{Ag} / \mathrm{Cu})$ nanoparticles [158] (reprinted with permission of Creative Commons Attribution License). (C). Various types of gold nanoparticles and their UV absorption (Reprinted with permission of Elsevier and Copyright Clearance Center): (a) spherical gold nanoparticles, (b) gold nanorods, (c) gold nanostars, (d) gold nanocages. [159] (D). Influence on optical absorption with (a) different materials and (b) different shapes of NPs [160] (Reprinted with permission from [160], 2019, Creative Commons Attribution-Noncommercial 3.0 Unported License.). (E) A schematic diagram of an ultrathin silicon solar cell representing $20 \mathrm{~nm}$-diameter Ag NPs periodically substituted on the Al gratings to enhance the light-trapping mechanism [154].

\subsection{Nanostructures at the Front Surface}

The top layer of the solar cell is a critical location at which to reduce light reflection and losses and increase light trapping so that light with low and high wavelengths can enter into the cells. This can be achieved by the deposition of an antireflection coating at the top surface. To couple incident light into an absorption layer, metallic nanoparticles can be utilized as subwavelength scattering elements [161]. Localized surface plasmons can be generated by appropriately engineering metallic nanoparticles to efficiently scatter the light. Because of the scattering of the metallic nanoparticles deposited at the top surface, the optical path length of the light can be enhanced inside the absorption layer. Jain et al. [162] investigated $\mathrm{TiO}_{2}$ film of $30 \mathrm{~nm}$ thickness as an antireflection coating (ARC) along with plasmonic Ag NPs $(90 \mathrm{~nm})$. Plasmonic Ag NPs were applied at the front surface (Figure 10a-c). The incident light reflection was reduced by the $\mathrm{TiO}_{2}$ film on the top Si surface and Ag NPs thanks to the plasmonic effect, which improved light trapping (Figure 10d). This combination led to an enhancement in the power conversion efficiency (PCE) (Figure 10e). The PCEs of a bare Si solar cell, a Si-cell with $\mathrm{TiO}_{2}$ as ARC, and a Si-cell with $\mathrm{TiO}_{2}$ as ARC along with $\mathrm{Ag}$ NPs were measured as $9.53 \%, 12.58 \%$, and $16.04 \%$, respectively. Thus, the ARC/plasmonic combination enhanced the PCE by $\sim 40 \%$. 


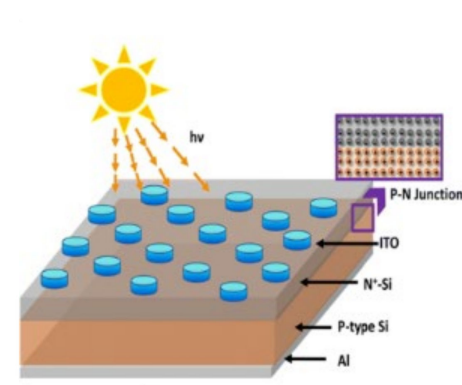

(a)

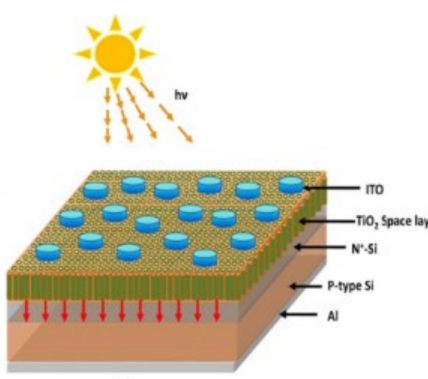

(b)

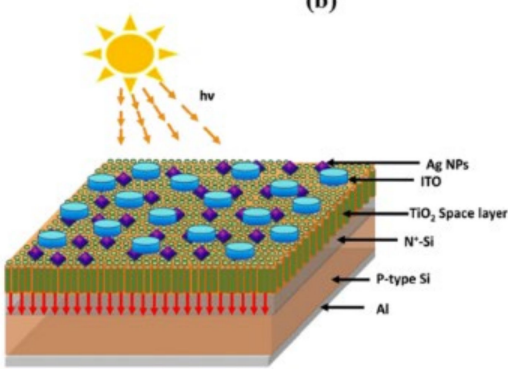

(c)
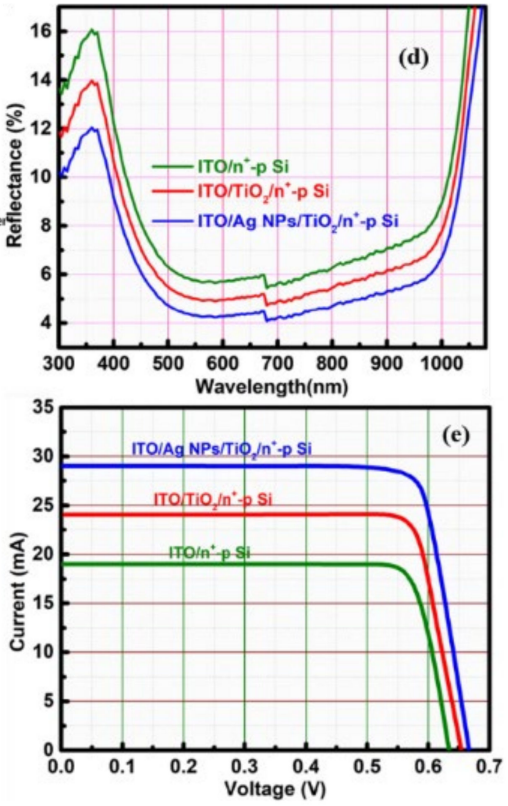

Figure 10. (a) Bare thin Si-based solar cell. (b) Si solar cell with $\mathrm{TiO}_{2}$ thin film as ARC. (c) Si solar cell with $\mathrm{TiO}_{2}$ film as ARC and Ag nanoparticles (NPs). (d) Reflectance spectra of the three prepared solar cell configurations. (e) I/V characteristics of the prepared solar cells [162]. (Reprinted with permission from [162], 2020, Springer Nature and Copyright Clearance Center).

\subsection{Plasmonic Back Reflectors}

After letting more light enter the solar cell, the second important purpose is to enhance the optical path length of the photons in the active layer. To obtain this goal, the inner side of the back surface of the cell needs to be textured properly to make longer wavelengths scatter and diffract back into the active absorption layer, as shown in Figure 8d. A plasmonic nanostructure can be applied in the thin-film solar cell to harvest the maximum amount of trapped light [163-165]. This plasmonic nanostructure can be designed to absorb different wavelengths of light, such as those in the infrared [166-168] and visible range [169].

Hungerford et al. [170] reported a back reflector based on Ag nanoparticles of hemispherical shape. With this, $72 \%$ absorption in the $400-600 \mathrm{~nm}$ spectral range was achieved. Crudgington et al. [171] reported on using a Ag nanoparticle array as a plasmonic back reflector in a thin-film solar cell. In the UV region at $140 \mathrm{~nm}$ spectral width, $80 \%$ absorption was achieved by the Ag array. Sun et al. [172] studied a new design for a thin-film solar cell back surface involving decorating the bottom surface of the silicon layer with Ag nanoparticles. By doing so, in the solar spectrum from $800-1200 \mathrm{~nm}, 50 \%$ of transmission losses were minimized. C. Sun et al. [11] suggested another design in which the back surface was textured with blazed grating to overcome the issue of transmission losses in the visible range in thin-film solar cells. This texturing solved the issue of transmission losses yet raised a recombination issue, which eventually decreased the overall efficiency. Desta et al. [173] reported on back reflector in a thin-film Si solar cell involving flat Ag with an overlying bilayer, which was a dielectric $\mathrm{TiO}_{2}$ layer with inverted nanopyramidal cavities, used to scatter light (Figure 11). With this approach, efficient light scattering was achieved. An increase in $\mathrm{J}_{\mathrm{sc}}$ and an efficiency increase from $14 \%$ to $17.5 \%$ was reported. 

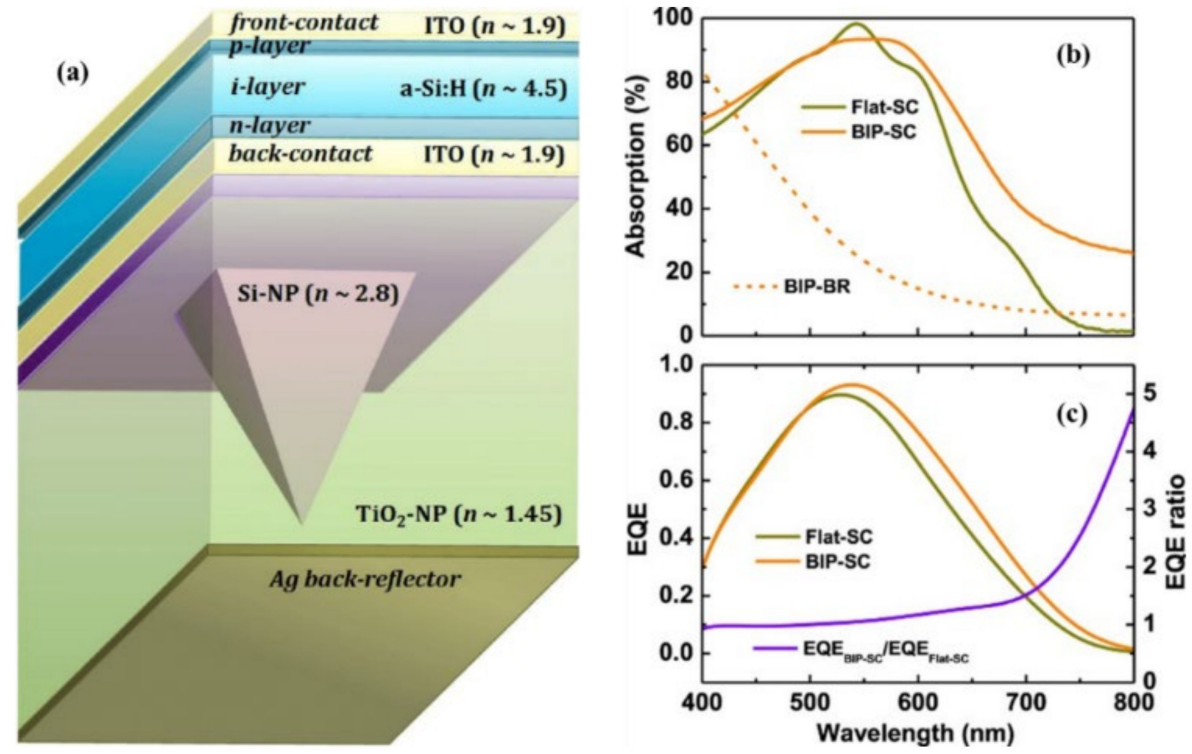

Figure 11. (a) Schematic illustration of a BLiS back reflector for $n-i-p$ Si thin-film solar cells. The $\mathrm{TiO}_{2}$-NP layer over the planar silver back reflector had inverted pyramid-shaped microcavities, which were further covered by a flat-topped Si-NP layer. (b) Total optical absorption by Flat-SC and BIP-SC devices (solid lines) and parasitic absorption by the BIP-BR (dashed line). (c) Measured EQE (left-hand side $y$-axis) spectra of Flat-SC and BIP-SC devices and EQE ratio (right-hand side $y$-axis) [173]. Reprinted with permission from [173], 2020, Creative Commons Attribution License (https:/ / creativecommons.org/licenses/by/4.0, accessed on 4 February 2020).

Sun et al. [172] demonstrated that light could be more efficiently prevented by cylindrical or rectangular Ag nanoparticles to transmit away from silicon than by other designs, as shown in Figure 12. This characteristic was ascribed to the interface area of $\mathrm{Ag} / \mathrm{Si}$, which was comparatively greater for cylindrical and rectangular nanoparticles. Therefore, they efficiently scattered light back into the silicon. This scattering effect was due to the excitation of the surface plasmons of Ag nanoparticles.

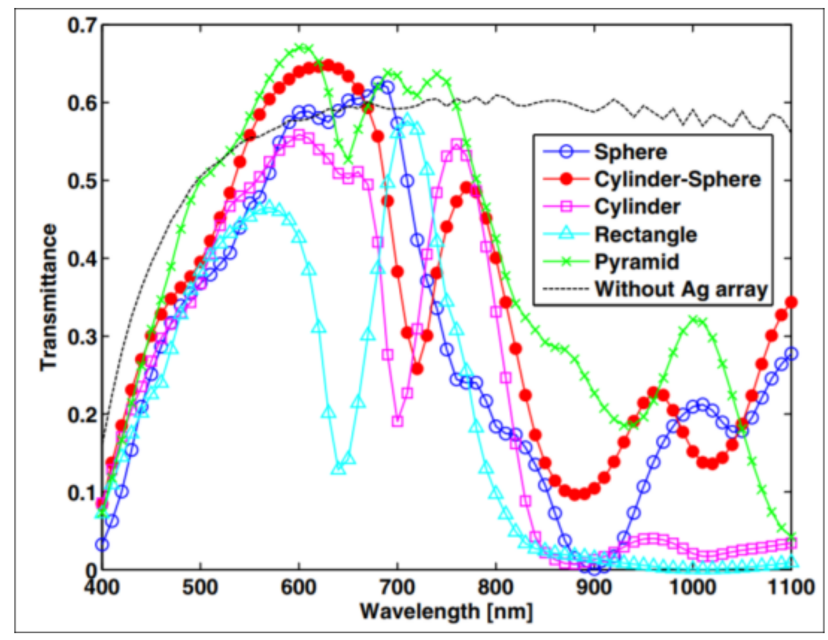

Figure 12. Bottom configuration: the silver nanoparticle arrays with individual particles shaped as rectangles or cylinders gave rise to the lowest transmittance curves [172]. Reprinted with permission from [172], 2012, American Chemical Society.

It was reported by Amalathas et al. and Eisele et al. [25,174] that periodic arrays of nanostructures as back reflectors of light constitute a highly promising methodology. They can help to couple the incident light and propagate in the absorber layer to harvest it at the 
fullest. The key to control the scattered light polarization and distribution lies in controlling the shape of the nanostructured periodic array. Optical path length within the absorption layer can be increased substantially by applying nanostructured periodic arrays as back reflectors. Haase et al. [175], Aissa et al. [176], Sai et al. [177], and Wang et al. [178] reported a wide range of range of nanostructure shapes, dimensions, and periodicities applied as back reflectors for light trapping. They explored how to optimize these parameters to trap and harvest the incident light efficiently in thin-film solar cells. In Figure 13a-d, four different cases are presented and then compared. Benefits of the double side microcone grating applied on an ultrathin c-silicon solar cell were studied by systematic rigorous coupled wave analysis (RCWA) [178].
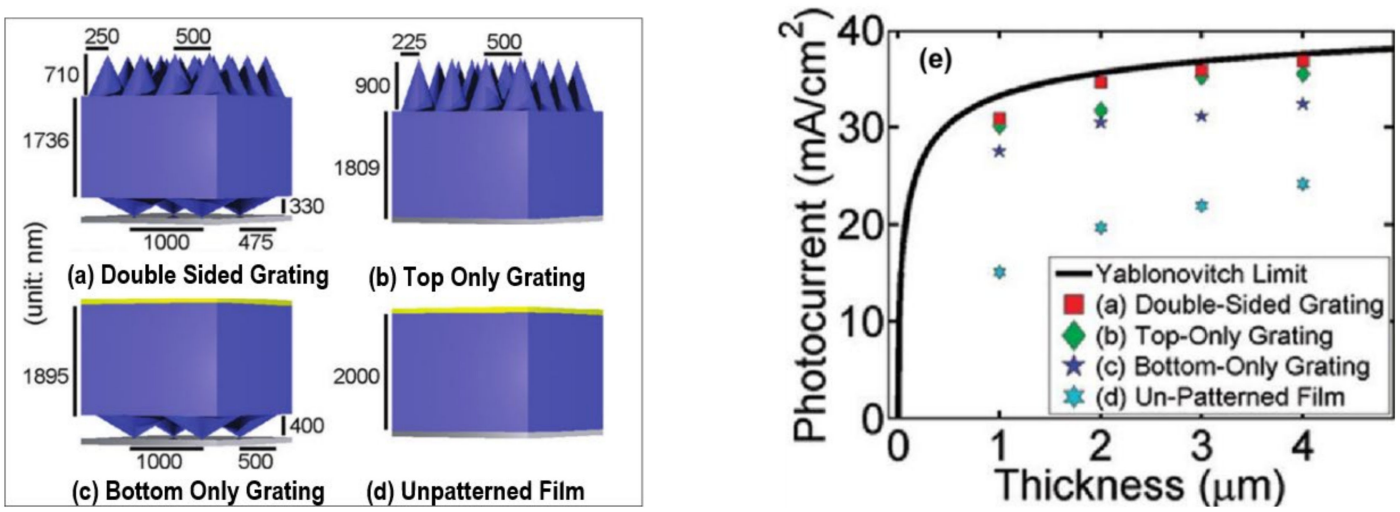

Figure 13. Three-dimensional silicon thin-film structures in air. From (a) to (d), blue represents silicon, gray represents a perfect electric conductor (PEC), and yellow represents nonabsorbing silicon nitride. The nanocones were made of silicon, as were the uniform layers, and they were placed in a two-dimensional square lattice either on the front or on the back surface of the film. (a) The optimized double-sided nanostructure. (b) The optimized top-only nanostructure. (c) The optimized bottom-only nanostructure with a thin layer of nonabsorbing silicon nitride on top. (d) The flat film with a thin layer of nonabsorbing silicon nitride on top [178]. (e) Photocurrents generated by structures as a function of their equivalent thicknesses. (Reprinted with permission from [178], 2012, American Chemical Society).

The optimized double-sided grating structure yielded a photocurrent of $34.6 \mathrm{~mA} / \mathrm{cm}^{2}$ at an equivalent thickness of $2 \mu \mathrm{m}$, which approached the Yablonovitch limit [179], as shown in Figure 13e. This methodology is appropriate to numerous thicknesses and is vigorous against metallic loss in the back reflector.

\subsection{Mismatch of the Front and Back Light Grating for Optimum Light Trapping}

Various other photonic crystal morphologies including nanopyramids, nanodomes, and nanowires have also been reported. Photonic crystal shape has strong effects when the size of the periodic array of the nanostructure is equal to or smaller than the wavelength of the incident light. Putnam et al. [180] demonstrated that the light trapping phenomenon has a limit dictated by the local photonic density of optical states. Therefore, trapping light can be substantially enhanced with photonic crystals for the absorption layer [181-183]. The numerous types of photonic crystals applied to solar cells include periodically arranged strips [184], nanodomes [185], nanopillars, nanoholes and nanowells [186].

Ding et al. [28] investigated a nanocone grating with architecture with a high aspect ratio and a dense periodicity of about $500 \mathrm{~nm}$. This configuration was applied at the front surface as an antireflection coating, and it was successfully demonstrated that a substantial increase in absorption could be obtained. Once applied at the back surface, low-aspect ratio nanocones in lower-density nanocone grating also considerably improved the absorption inside the device (Figure 14). By implementing this grating at the front and the rear sides 
simultaneously, a guided coupling was achieved. For a $2 \mu \mathrm{m}$ thin $\mathrm{Si}$ cell, the optimal periodicity for light tapping of the nanocones on the back surface was found to be $1000 \mathrm{~nm}$.

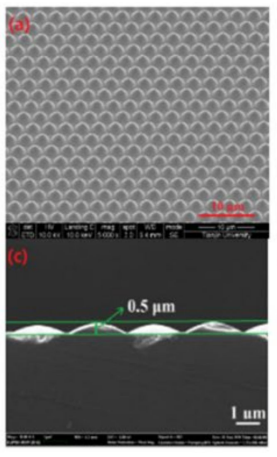
I픔

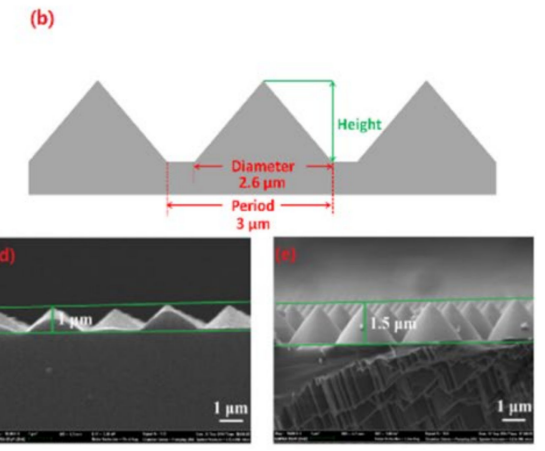

(A)

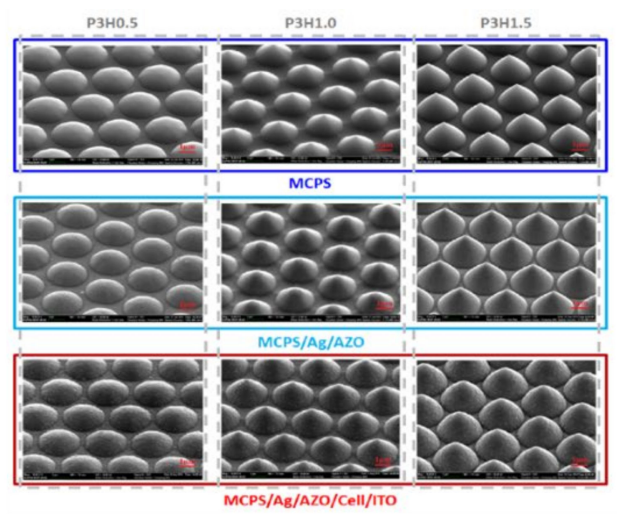

(B)

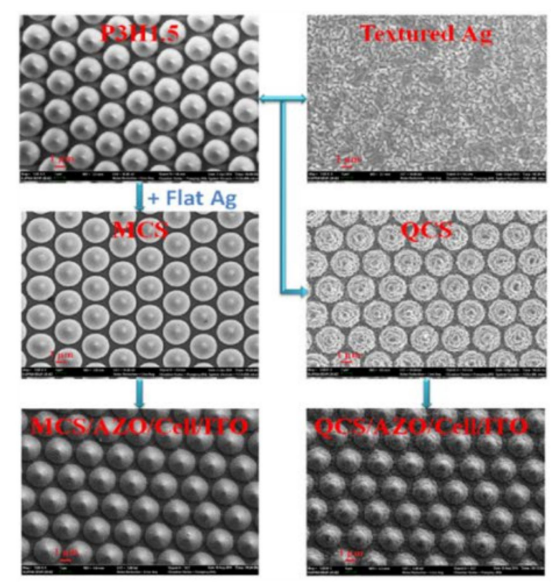

(C)

Figure 14. (A) (a) SEM image of a microcone-patterned substrate (MCPS) with a uniform microcone pattern; (b) schematic structure of the microcone pattern; (c-e) cross-sectional SEM of MCPSs with different H/P. (B) SEM images of MCPS (P3H0.5, P3H1.0, P3H1.5), MCPS coated with Ag/AZO, and a corresponding solar cell. (C) SEM images of microcone structure (MCS), quasicrystal structure (QCS), and MCS-based and QCS-based a-SiGe:H solar cells [28] (reprinted with permission from [28], 2017, Creative Commons CC-BY license).

Si-based nanowires arrays have also been applied for solar cell applications. Solar cells with radial $\mathrm{p}-\mathrm{n}$ junctions containing $\mathrm{Si}$ nanowire arrays were demonstrated to offer wide band optical absorption properties and a higher collection of charge carriers. Nanowire array patterning, the aspect ratio, and the distance between the wires strongly govern both the light absorption and the charge carrier collection efficiency [180,187].

Zhu et al. [185] reported (Figure 15) that a-Si:H solar cells deposited on a substrate patterned with $280 \mathrm{~nm}$-thick nanodomes enhanced the refractive index matching with air and increased absorption and optical path length. This combination of a-Si:H with nanodome configuration was very effective because a-Si:H absorbed most of the 400-500 nm wavelengths. Compared with the $65 \%$ absorption of the planar configuration, absorption of light increased to $94 \%$ in the $400-800 \mathrm{~nm}$ wavelength range with nanodomes, which in turn improved the PCE. 
a)

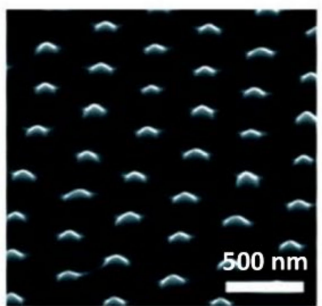

b)

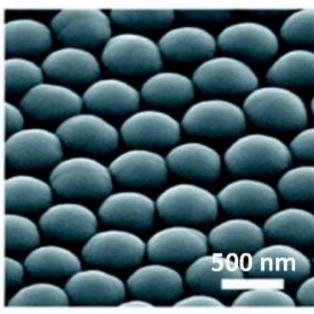

c)

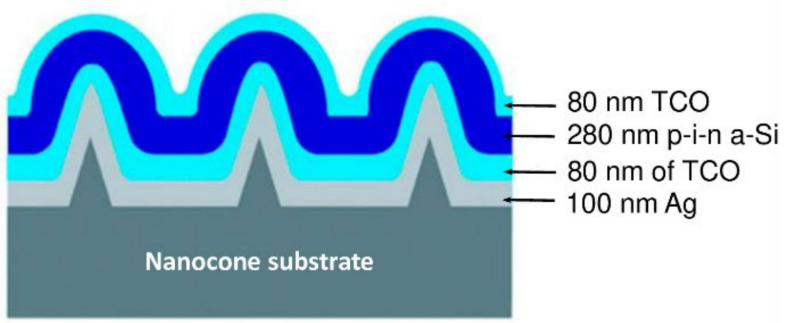

Figure 15. SEM images at $45^{\circ}$ on (a) nanocone-patterned quartz substrate and (b) a-Si:H nanodome solar cells after deposition of all layers on nanocones (scale bar $500 \mathrm{~nm}$ ). (c) Schematic illustration of the cross-sectional view of a-Si:H nanodome solar cells (Reprinted with permission from [185] 2010, American Chemical Society).

\section{Different Arrangements of Plasmonic Nanostructures in PV and Mechanisms}

In device structure, the incorporation of metal nanoparticles as plasmons can enhance device performance by different mechanisms depending on their placement. There are several ways to incorporate metallic nanoparticles, such as into the absorption layer, distributed in the charge transportation layer, applied onto the electrodes, or in between the layers as a sandwich structure. Table 1 summarizes some reported studies in which plasmonic nanoparticles were applied in organic solar cells [188] along with the recorded performance. Mainly nanoparticles of $\mathrm{Ag}, \mathrm{Au}, \mathrm{Ag} / \mathrm{Au}$ (bimetallic) were incorporated in the organic PVs to harvest more light energy. Au in the active layer as a plasmonic nanoparticle performed better than Ag. Ag/Au bimetallic nanoparticles in the HTL also boosted the PCE. There is no straightforward mechanism in terms of specific nanomaterials as plasmonic nanoparticles, because there are different organic solar cell configurations. However, incorporation of nanoparticles in the active layer of the OPV is advantageous. 
Table 1. Summary of plasmonic nanoparticle applications in organic solar cells and effects on cell performance.

\begin{tabular}{|c|c|c|c|c|c|c|c|}
\hline Ref. & Structure & $\begin{array}{c}\text { Spatial } \\
\text { Arrangement }\end{array}$ & $\begin{array}{c}\mathrm{J}_{\mathrm{sc}} \\
\left(\mathrm{mA} / \mathrm{cm}^{2}\right)\end{array}$ & $\begin{array}{c}\mathrm{J}_{\mathrm{sc}} \\
\text { Enhancement } \\
(\%)\end{array}$ & $\begin{array}{l}\text { Efficiency } \\
\quad(\eta \%)\end{array}$ & $\begin{array}{c}\text { Efficiency } \\
\text { Increase (\%) }\end{array}$ & Mechanism \\
\hline [13] & $\begin{array}{c}\text { ITO/PEDOT:PSS/P3HT: } \\
\text { PCBM/embedded Ag (NPs)/Al }\end{array}$ & Embedded in active layer & 8.67 to 10.64 & 18.2 & 3.19 to 4.21 & $\sim 23$ & LSPR and light scattering \\
\hline [189] & $\begin{array}{c}\text { ITO/PEDOT:PSS/BHJ active layer } \\
\text { with } \mathrm{Ag} \text { (nanocluster, } 40 \\
\mathrm{~nm} \text { )/ } \mathrm{TiOx} / \mathrm{Al}\end{array}$ & $\begin{array}{c}\text { Ag nanoclusters } \\
\text { embedded in active layer }\end{array}$ & 10.79 to 11.61 & 7.6 & 6.3 to 7.1 & 11.3 & $\begin{array}{l}\text { Improved absorption by } \\
\text { light scattering, increasing } \\
\text { the optical length }\end{array}$ \\
\hline [140] & $\begin{array}{c}\text { ITO/PEDOT:PSS }(30 \mathrm{~nm}) / \\
\text { P3HT:PCBM }(220 \mathrm{~nm}): \mathrm{Ag}(\text { sphere } \\
\text { and prism)/Ca }(80 \mathrm{~nm}) / \mathrm{Al}(100 \mathrm{~nm})\end{array}$ & $\begin{array}{l}\text { Ag NPs and nanoprisms } \\
\text { embedded in active layer }\end{array}$ & 10.61 to 8.99 & 18 & 3.6 to 4.3 & 16.3 & $\begin{array}{l}\text { Broadband resonance due to } \\
\text { excitation of versatile } \\
\text { plasmonic resonances }\end{array}$ \\
\hline [190] & $\begin{array}{c}\text { ITO/PEDOT:P:SS/BHJ active layer } \\
\text { with Au NPs }(70 \mathrm{~nm}) \text { (truncated } \\
\text { octahedraon)/TiOx/Al }\end{array}$ & Embedded in active layer & 10.65 to 11.16 & 4.5 & 4.54 to 6.45 & 30 & $\begin{array}{l}\text { Light absorption caused by } \\
\text { the light scattering of Au } \\
\text { NPs in the active layer }\end{array}$ \\
\hline [191] & $\begin{array}{l}\text { ITO/PEDOT:PSS/PTB7:PC70BM/Au } \\
\text { nanospheres }(30 \mathrm{~nm}) / \mathrm{TiOx} / \mathrm{Al}\end{array}$ & $\begin{array}{c}\text { Au nanospheres } \\
\text { embedded into active layer }\end{array}$ & 15.31 to 15.70 & 2.5 & 7.02 & 6.7 & $\begin{array}{c}\text { Increased light absorption by } \\
\text { light scattering of embedded } \\
\text { Au nanospheres }\end{array}$ \\
\hline [192] & $\begin{array}{l}\text { ITO/rGO:ZnO/P3HT:PCBM:Ag/Au } \\
\text { (NPs or NRs)/MoO3/Ag }\end{array}$ & $\begin{array}{c}\text { Embedded Ag/Au NPs } \\
\text { and NRs }\end{array}$ & 10.99 to 12.21 & 10 & 3.77 to 4.85 & $\sim 28$ & LSPR and light scattering \\
\hline [194] & $\begin{array}{c}\text { ITO/PEDOT:PSS/PBDT- } \\
\text { TS1:PC71BM/Au nanostars in } \\
\text { active and PEDOT/Ca }(\mathrm{ZnO}) / \mathrm{Al}\end{array}$ & $\begin{array}{c}\text { Embedded in active and } \\
\text { HTL }\end{array}$ & 18.37 to 19.24 & 5 & 9.97 to 10.50 & $\sim 5$ & $\begin{array}{l}\text { Plasmonic asymmetric } \\
\text { modes of Au NSs transferred } \\
\text { the optical power in ETL to } \\
\text { active layer and improved } \\
\text { the active layer absorption }\end{array}$ \\
\hline [195] & $\begin{array}{c}\text { PEDOT/Au nanorods (NRs) @ } \\
\text { SiO2/PTB7:PC71BM }\end{array}$ & $\begin{array}{c}\text { Sandwiched between CTL } \\
\text { and active layer }\end{array}$ & 16.5 to 21.2 & 22 & 7.52 to 9.55 & $\sim 28$ & $\begin{array}{c}\text { Scattering, } \\
\text { LSPR }\end{array}$ \\
\hline [10] & PCDTBT:PC71BM/Au NRs in TiOx & $\begin{array}{c}\text { Incorporated Au NRs in } \\
\text { back ETL }\end{array}$ & 10.87 to 12.03 & 9.6 & 5.96 to 6.75 & $\sim 13$ & Backward scattering \\
\hline & PTB7:PC71BM/Au NRs in TiOx & $\begin{array}{c}\text { Incorporated } \mathrm{Au} \text { NRs in } \\
\text { back ETL }\end{array}$ & 16.27 to 17.17 & 5.2 & 7.43 to 8.01 & $\sim 8$ & Backward scattering \\
\hline [196] & $\begin{array}{l}\text { PTB7:PC71BM/ZnO@carbon } \\
\text { nanotubes (CNT)-Au (ETL) }\end{array}$ & $\begin{array}{c}\text { Embedded ZnO@CNT-Au } \\
\text { as ETL }\end{array}$ & 16.18 to 16.81 & 4 & 7.0 to 7.9 & $\sim 13$ & Forward scattering \\
\hline [197] & PCDTBT:PC71BM/ZnO (ETL) & $\begin{array}{c}\text { Embedded Au arrows in } \\
\text { ETL }\end{array}$ & 14.70 to 17.40 & 15.5 & 6.14 to 7.82 & $\sim 27$ & Forward scattering, LSPR \\
\hline [198] & PBDTTT-CF:PC71BM/ZnO (ETL) & Embedded Au NPs in ETL & 14.49 to 15.81 & 8.3 & 6.67 to 7.86 & $\sim 18$ & Forward scattering, LSPR \\
\hline
\end{tabular}


Table 1. Cont.

\begin{tabular}{|c|c|c|c|c|c|c|c|}
\hline Ref. & Structure & $\begin{array}{c}\text { Spatial } \\
\text { Arrangement }\end{array}$ & $\begin{array}{c}\mathrm{J}_{\mathrm{sc}} \\
\left(\mathrm{mA} / \mathrm{cm}^{2}\right)\end{array}$ & $\begin{array}{c}\mathrm{J}_{\mathrm{sc}} \\
\text { Enhancement } \\
(\%)\end{array}$ & $\begin{array}{l}\text { Efficiency } \\
\quad(\eta \%)\end{array}$ & $\begin{array}{c}\text { Efficiency } \\
\text { Increase (\%) }\end{array}$ & Mechanism \\
\hline$[199,200]$ & P3HT:ICBA/WO3 (HTL) & $\begin{array}{c}\text { Embedded Cu NPs in rear } \\
\text { HTL }\end{array}$ & 8.71 to 11.79 & 26 & 4.65 to 6.38 & $\sim 37$ & Backward scattering \\
\hline [201] & P3HT:ICBA/WO3 (HTL) & $\begin{array}{l}\text { Embedded Ag-Au } \\
\text { bimetallic NPs in rear HTL }\end{array}$ & 7.91 to 11.01 & 28 & 4.57 to 6.55 & $\sim 43$ & Backward scattering \\
\hline [87] & $\begin{array}{c}\text { PTB7:PCBM/PEDOT/Ag nanodot } \\
\text { array/ITO }\end{array}$ & $\begin{array}{l}\text { Sandwiched between HTL } \\
\text { and anode }\end{array}$ & 17.43 to 23.26 & 25 & 7.70 to 10.72 & $\sim 39$ & LSPR, forward scattering \\
\hline [202] & PTB7:PC71BM/ZnO/Au NPs/ITO & $\begin{array}{l}\text { Incorporated Au NPs } \\
\text { between ETL and cathode }\end{array}$ & 15.53 to 15.69 & 1 & 6.75 to 7.27 & $\sim 7$ & MDM absorber \\
\hline [203] & $\begin{array}{c}\text { PTB7:PC71BM/nano- } \\
\text { biohybrid } / \mathrm{ZnO} / \\
\text { ITO }\end{array}$ & $\begin{array}{l}\text { Incorporated Ag } \\
\text { prisms-LHCII between the } \\
\text { active layer and ETL }\end{array}$ & 16.01 to 17.99 & 11 & 9.03 to 10.57 & $\sim 17$ & LSPR \\
\hline [204] & $\begin{array}{l}\text { PBDTTT-C:PC60BM/Au } \\
\text { NPs/PEDOT/ITO }\end{array}$ & $\begin{array}{c}\text { Incorporated Au NPs } \sim 15 \\
\text { nm between the active and } \\
\text { HTL }\end{array}$ & 10.62 to 11.74 & 10 & 4.78 to 5.52 & $\sim 15$ & LSPR \\
\hline [205] & ITO/ZnO/P3HT:PC61BM/MoO3/Al & $\begin{array}{c}\text { Reference Ag NWs } \\
\text { between cathode and ETL } \\
\text { Ag NWs between ETL and } \\
\text { active layer }\end{array}$ & 8.13 to 9.87 & 17.6 & 3.10 to 4.05 & $\sim 23$ & LSPR \\
\hline [41] & $\begin{array}{c}\text { ITO/ZAZ/P3HT:PC61BM/PEDOT: } \\
\text { PSS/Ag }\end{array}$ & $\begin{array}{c}\text { Applied } \\
\text { ZnO/AgNWs/ZnO (ZAZ) } \\
\text { as transparent electrode }\end{array}$ & 9.75 to 11.6 & 16 & 3.16 to 3.53 & $\sim 12$ & $\begin{array}{l}\text { Higher transmission above } \\
\qquad 450 \mathrm{~nm}\end{array}$ \\
\hline [39] & $\begin{array}{l}\text { P3HT:PC61BM/PEDOT/ } \\
\text { Au (flat or grating) }\end{array}$ & $\begin{array}{l}\text { Applied Au grating as rear } \\
\text { electrode }\end{array}$ & 6.13 to 6.83 & 10.2 & 3.03 to 3.53 & $\sim 16$ & $\begin{array}{l}\text { SPP, photonic waveguide } \\
\text { mode }\end{array}$ \\
\hline [206] & $\begin{array}{l}\text { ITO/PEDOT:PSS:Ag Nanoparticles } \\
\text { (NPs) }(57 \mathrm{~nm}) / \mathrm{CuPc} / \mathrm{C} 60\end{array}$ & $\begin{array}{c}\text { Embedded Ag NPs into } \\
\text { photoconductor transport } \\
\text { layer }\end{array}$ & 4.01 to 5.01 & 20 & 0.663 to 0.925 & $\sim 28$ & LSPR \\
\hline
\end{tabular}


In Table 2, research involving incorporation of nanomaterials as plasmonic nanoparticles in metal-halide perovskite solar cells is summarized to understand the effect of said incorporation. There are many different configurations of PSCs, and each one has its own performance mechanism and explanation. In most cases, the plasmonic nanoparticles improved the photocurrent. To have high carrier generation rate, the amount of absorption in the active layer must be increased. The increase in PCE can be attributed to an increase in short-circuit current density $\left(\mathrm{J}_{\mathrm{sc}}\right)$ due to an increase in optical path length and absorption. NPs exhibit the ability to increase the optical path length of photons in the device via near-field and far-field enhancement (plasmonic scattering) and consequently may act to improve the photon-to-electron conversion efficiency ( $\triangle \mathrm{IPCE}$ ) and PCE of PSCs. Reducing the thickness of the active layer reduces the amount of absorption, but this can be compensated by stimulating the plasmons of metal NPs. Since the thickness of the active layer and recombination are directly related, reducing the thickness of the active layer can have a positive effect on the recombination rate.

Table 2. Summary of studies in which plasmonic nanoparticles were applied in metal-halide perovskite solar cells along with the resulting PV performance.

\begin{tabular}{|c|c|c|c|c|c|c|}
\hline Ref. & Structure & $\begin{array}{c}\mathrm{J}_{\mathrm{sc}} \\
\left(\mathrm{mA} / \mathrm{cm}^{2}\right)\end{array}$ & $\begin{array}{c}\mathrm{J}_{\mathrm{sc}} \\
\text { Enhancement } \\
(\%)\end{array}$ & $\begin{array}{l}\text { Efficiency } \\
\quad(\mathbf{n} \%)\end{array}$ & $\begin{array}{c}\text { Efficiency } \\
\text { Increase (\%) }\end{array}$ & Mechanism \\
\hline [207] & $\begin{array}{c}\text { ITO/PEDOT:PSS/MAPbI } / \text { / Ag NPs } \\
\text { (79 nm)/PCBM/LiF/Al }\end{array}$ & 19.89 to 24.41 & 18.5 & 11.63 to 13.46 & $13.6 \%$ & $\begin{array}{l}\text { Improved } \mathrm{J}_{\mathrm{sc}} \text { and overall } \\
\text { device performance due } \\
\text { to enhanced absorption } \\
\text { via LSPR and light optical } \\
\text { path length increase. }\end{array}$ \\
\hline [208] & $\begin{array}{c}\mathrm{ITO} / \mathrm{Au} \text { NPs }(120 \mathrm{~nm}): \mathrm{QD}- \\
\mathrm{CsPbBr}_{3} / \mathrm{PEDOT}_{\mathrm{PSS} / \mathrm{MAPbI}_{3} /} \\
\mathrm{C}_{60} / \mathrm{Ag}\end{array}$ & 20.6 to 22.5 & 9 & 8.53 to 10.9 & 27.8 & $\begin{array}{l}\text { LSPR excitation and light } \\
\text { scatterring. }\end{array}$ \\
\hline [209] & $\begin{array}{l}\text { ITO/PEDOT:PSS/MAPbI } / \text { / PCBM } / \mathrm{Ag} \\
\text { (nanocubes)/BCP / Ag }\end{array}$ & 19.5 to 21.4 & 9 & 11.9 to 13.3 & 10.5 & $\begin{array}{l}\text { Plasmonic Ag nanocubes } \\
\text { coupling with Ag back } \\
\text { electrode. }\end{array}$ \\
\hline \multirow[t]{3}{*}{ [210] } & $\begin{array}{l}\mathrm{ITO} / \mathrm{TiO}_{2} / \mathrm{ZrN} / \mathrm{SiO}_{2} \mathrm{NPs} \\
(75 \mathrm{~nm} \text { core } / 40 \mathrm{~nm} \\
\text { shell }) / \mathrm{MASnI}_{3} / \mathrm{Spiro-} \\
\text { OMeTAD } / \mathrm{Au}\end{array}$ & 27 to 40.3 & 33 & 12.9 to 20 & 35.5 & $\begin{array}{l}\text { Attributed to the } \\
\text { enhancement in the } \\
\text { plasmonic surface } \\
\text { plasmon directivity by the } \\
\text { dielectric shell. }\end{array}$ \\
\hline & $\begin{array}{c}\mathrm{ITO}(150 \mathrm{~nm}) / \mathrm{TiO}_{2}(40 \mathrm{~nm}) / \mathrm{TiN} \\
\text { NPs }(100 \mathrm{~nm}) / \mathrm{MASnI}_{3}(350 \\
\mathrm{nm}) / \text { Spiro-OMeTAD }(200 \mathrm{~nm}) / \mathrm{Au} \\
(100 \mathrm{~nm})\end{array}$ & 27 to 36.91 & 27 & 12.9 to 18.2 & 29 & $\begin{array}{l}\text { Absorption enhancement } \\
\text { due to NP plasmonic } \\
\text { effect acting as wave } \\
\text { guide to direct sunlight by } \\
\text { LSPR, forming SPPs at the } \\
\text { air-TiN interface. }\end{array}$ \\
\hline & $\begin{array}{c}\mathrm{ITO}(150 \mathrm{~nm}) / \mathrm{TiO}_{2}(40 \mathrm{~nm}) / \mathrm{ZrN} \\
\text { NPs }(100 \mathrm{~nm}) / \mathrm{MASnI}_{3}(350 \\
\mathrm{nm}) / \text { Spiro-OMeTAD }(200 \mathrm{~nm}) / \mathrm{Au} \\
(100 \mathrm{~nm})\end{array}$ & 27 to 34.2 & 21 & 12.9 to 16.6 & 22.3 & $\begin{array}{l}\text { Plasmonic resonance } \\
\text { enhancement at NIR } \\
\text { wavelengths. }\end{array}$ \\
\hline [211] & $\begin{array}{c}\mathrm{FTO} / \mathrm{TiO}_{2}(50 \mathrm{~nm}) / \mathrm{Al}_{2} \mathrm{O}_{3}(130 \mathrm{~nm}) \\
\text { with } \mathrm{Au}(80 \mathrm{~nm}) @ \mathrm{SiO}_{2}(8 \mathrm{~nm})+ \\
\mathrm{MAPbI}_{3} / \text { Spiro-OMeTAD } / \mathrm{Ag}\end{array}$ & 14.76 to 16.91 & 13 & 10.7 to 11.4 & 6 & $\begin{array}{l}\text { Enhanced photocurrent } \\
\text { due to enhanced light } \\
\text { absorption and plasmonic } \\
\text { localized heating. }\end{array}$ \\
\hline [212] & $\begin{array}{c}\mathrm{FTO} / \mathrm{Ag} @ \mathrm{TiO}_{2} / \mathrm{Al}_{2} \mathrm{O}_{3}+ \\
\mathrm{MAPbI}_{3} / \text { Spiro-OMeTAD } / \mathrm{Ag}\end{array}$ & 17.3 to 20.2 & 14.35 & 11.4 to 13.5 & 16 & $\begin{array}{l}\text { Photocurrent } \\
\text { improvement due to } \\
\text { highly polarizable } \\
\text { metallic NPs. }\end{array}$ \\
\hline [213] & $\begin{array}{c}\mathrm{FTO} / \mathrm{c}-\mathrm{TiO}_{2} / \mathrm{m}-\mathrm{TiO}_{2} / \mathrm{Au}-\mathrm{Ag} \text { alloy } \\
\mathrm{NPs} \\
\text { (popcorn-shaped)/MAPbI } / \text { Spiro- } \\
\text { OMeTAD } / \mathrm{Ag}\end{array}$ & 15.51 to 16.46 & 6 & 8.9 to 10.3 & $15.7 \%$ & $\begin{array}{c}\text { Plasmonic popcorn NPs } \\
\text { led to faster charge } \\
\text { transfer at } \\
\mathrm{TiO}_{2}-\text { perovskite } \\
\text { interface, resulting in } \\
\text { increased PCE. }\end{array}$ \\
\hline [214] & $\begin{array}{c}\mathrm{FTO} / \mathrm{TiO}_{2} / \mathrm{SnO}_{2} / \mathrm{CsFAMAPbI} \mathrm{Br}_{3} / \mathrm{Ag} \\
\mathrm{NR} \text { (buffer } \\
\text { layer)Spiro-OMeTAD } / \mathrm{Au}\end{array}$ & 21.08 to 22.18 & 5 & 18.50 to 20.29 & 9 & $\begin{array}{l}\text { Ag NRs increased the } \\
\text { absorption by the LSPR } \\
\text { effect. }\end{array}$ \\
\hline
\end{tabular}


Table 2. Cont.

\begin{tabular}{|c|c|c|c|c|c|c|}
\hline Ref. & Structure & $\begin{array}{c}\mathrm{Jsc}_{\mathrm{sc}} \\
\left(\mathrm{mA} / \mathrm{cm}^{2}\right)\end{array}$ & $\begin{array}{c}\mathrm{J}_{\mathrm{sc}} \\
\text { Enhancement } \\
(\%)\end{array}$ & $\begin{array}{l}\text { Efficiency } \\
\quad(\mathbf{n} \%)\end{array}$ & $\begin{array}{c}\text { Efficiency } \\
\text { Increase (\%) }\end{array}$ & Mechanism \\
\hline [215] & $\begin{array}{c}\mathrm{ITO} / \mathrm{TiO}_{2} / \mathrm{Au} @ \mathrm{TiO}_{2} \\
(\mathrm{NR}) / \mathrm{MAPbI}_{3} / \text { Spiro-OMeTAD } / \mathrm{Au}\end{array}$ & 20.78 to 22.27 & 7 & 15.76 to 16.35 & 20.10 & $\begin{array}{c}\text { Facilitated carrier transfer } \\
\text { or separation in the } \\
\text { presence of plasmonic } \\
\text { NPs. }\end{array}$ \\
\hline [216] & $\begin{array}{l}\text { FTO/PEDOT:PSS + Ag } \\
\mathrm{NPs} / \mathrm{MAPbI}_{3} / \mathrm{PCBM} / \mathrm{Al}\end{array}$ & 15.06 to 15.47 & 3 & 4.17 to 5.58 & 25.3 & $\begin{array}{c}\text { Plasmons induced } \\
\text { enhanced absorption and } \\
\text { superior photogenerated } \\
\text { carrier separation and } \\
\text { transport via the Ag NPs } \\
\text { in the perovskite active } \\
\text { material. }\end{array}$ \\
\hline [217] & $\begin{array}{c}\mathrm{FTO} / \mathrm{c}-\mathrm{TiO}_{2} / \mathrm{TiO}_{2} \text { (nanocolumns, } \\
\mathrm{NC}) / \mathrm{Cs}_{0} \cdot 05\left(\mathrm{FA}_{0 \cdot 83} \mathrm{MA}_{0} \cdot 17\right)_{0} \cdot \\
{ }_{95} \mathrm{~Pb}\left(\mathrm{I}_{0} \cdot 83 \mathrm{Br}_{0 \cdot 17}\right)_{3} / \text { SpiroOMeTAD } / \mathrm{Au}\end{array}$ & 19.27 to 20.19 & 4.6 & 15.31 to 16.38 & 6.5 & $\begin{array}{l}\mathrm{TiO}_{2} \mathrm{NCs} \text { improved the } \\
\text { performance of perovskite } \\
\text { halide solar cells in terms } \\
\text { of charge transport, light } \\
\text { harvesting, and stability. }\end{array}$ \\
\hline [218] & $\begin{array}{c}\mathrm{FTO} / \mathrm{c}-\mathrm{TiO}_{2} / \mathrm{Au} @ \mathrm{TiO}_{2} \mathrm{NPs} \\
\text { embedded in p- } \\
\mathrm{TiO}_{2} / \mathrm{MAPbI}_{3} / \text { Spiro-OMeTAD/Ag }\end{array}$ & 17.40 to 23.12 & 25 & 12.59 to 18.24 & 44 & $\begin{array}{c}\text { Improvement due to } \\
\text { exciton generation rate, } \\
\text { enhanced exciton } \\
\text { dissociation probability, } \\
\text { and efficient carrier } \\
\text { transfer/collection } \\
\text { induced by the LSPR } \\
\text { effect. }\end{array}$ \\
\hline [219] & $\begin{array}{c}\mathrm{ITO} / \mathrm{ZnO} / \mathrm{MAPbI}_{3} / \mathrm{Au} \\
\text { (nanostars)/Spiro-OMeTAD/Ag }\end{array}$ & 17.43 to 18.21 & 4.3 & 11.98 to 13.97 & 14 & $\begin{array}{l}\text { Absorption improved by } \\
\text { Au NSs because of SPR } \\
\text { and backscattering effects. }\end{array}$ \\
\hline [220] & $\begin{array}{c}\mathrm{FTO} / \mathrm{ZnO} / \mathrm{ZnO} \\
\mathrm{NR} / \mathrm{MAPbI} / \text { spiro-OMeTAD/Au }\end{array}$ & 18.07 to 20.56 & 12.1 & 14.51 to 16.77 & $\sim 14$ & LSPR. \\
\hline [208] & $\begin{array}{l}\text { 120AuNPs:quantum dots (QD)- } \\
\mathrm{CsPbBr}_{3} / \mathrm{PEDOT}_{\mathrm{PSS} / \mathrm{MAPbI}_{3}}\end{array}$ & 20.6 to 22.5 & 8.4 & 8.53 to 10.9 & $\sim 27.8$ & $\begin{array}{l}\text { LSPR excitation by } \\
\text { resonance interaction. }\end{array}$ \\
\hline [221] & $\begin{array}{c}\text { ITO/PEDOT:PSS/CH} \mathrm{CH}_{3} \mathrm{NbI}_{3} / \\
\mathrm{PC}_{61} \mathrm{BM} / \mathrm{Al}\end{array}$ & 16.7018 .15 to & 8 & 10.54 to 11.74 & $\sim 10.22$ & $\begin{array}{l}\text { Subwavelength antenna } \\
\text { due to LSPR excitation. }\end{array}$ \\
\hline
\end{tabular}

In Table 3, the plasmonics effects of nanoparticles in silicon solar cells are tabulated and the respective effects on cell performance and mechanisms are summarized. In thin-film silicon solar cells, plasmonic effects constitute an emerging technology with promising application in the solar cell fabrication industry. It uses the nanoscale properties of $\mathrm{Ag}, \mathrm{Au}$, $\mathrm{Al}, \mathrm{Ti}, \mathrm{Cu}, \mathrm{SiO}_{2}$, etc. nanoparticles incorporated in the interface between the metal and dielectric contacts to enhance the light-trapping properties of thin-film silicon solar cells by increasing the absorption capacity and the generation of hot electrons, which in turn enhance the photocurrents in the solar cell. Plasmonic nanoparticles applied on the front (i.e., top) surface of the silicon solar cell were most effective and easily deposited.

Table 3. Summary of research in which plasmonic nanoparticles were applied in silicon solar cells.

\begin{tabular}{|c|c|c|c|c|}
\hline Ref. & Silicon Solar Cell & Plasmonic Type & Position & Achievements \\
\hline [222] & $\begin{array}{l}\text { Amorphous silicon } \\
\text { (a-Si) thin-film solar cell }\end{array}$ & $\begin{array}{c}\mathrm{SiO}_{2} \text { nanoparticles } \\
(70 \mathrm{~nm}) \\
\mathrm{Ag} \text { hemispheres } \\
(110 \mathrm{~nm})\end{array}$ & $\begin{array}{l}\text { Front } \\
\text { Rear }\end{array}$ & $\begin{array}{c}\text { Increase in current short-circuit } \\
\text { density of } 21 \% \text {; increase in conversion } \\
\text { efficiency of } 18 \% \text {. }\end{array}$ \\
\hline [223] & a-Si solar cell & $\begin{array}{c}\text { Double sided } \\
\text { plasmonic bimetallic } \\
\text { (Al-Cu) nanograting } \\
\text { Al (60 nm width) } \\
\text { Cu (50 nm width) }\end{array}$ & Front & $\begin{array}{l}\text { Improvement in absorption of } 40 \% \\
\text { and in } \mathrm{J}_{\mathrm{sc}} \text { of } 22.30 \mathrm{~mA} / \mathrm{cm}^{2} \text { (compared } \\
\text { with } 16.46 \mathrm{~mA} / \mathrm{cm}^{2} \text { without grating). }\end{array}$ \\
\hline
\end{tabular}


Table 3. Cont.

\begin{tabular}{|c|c|c|c|c|}
\hline Ref. & Silicon Solar Cell & Plasmonic Type & Position & Achievements \\
\hline [162] & $\begin{array}{l}\text { Crystalline Si solar cell } \\
\text { with } \mathrm{TiO}_{2} \text { as ARC }\end{array}$ & Ag NPs $(90 \mathrm{~nm})$ & Front & $\begin{array}{l}\text { Conversion efficiency increased from } \\
9.53 \% \text { to } 16.04 \% \text {, which was attributed } \\
\text { to plasmonic effect. }\end{array}$ \\
\hline [224] & $\begin{array}{l}\text { Planar silicon solar } \\
\text { cells with } \mathrm{Al}_{2} \mathrm{O}_{3} \text { layers }\end{array}$ & $\begin{array}{l}\text { Random-sized Ag NPs } \\
\qquad(20-140 \mathrm{~nm})\end{array}$ & Front & $\begin{array}{l}\text { EQE increased by } 19.2 \% \text { at } 700 \mathrm{~nm} \text {, } \\
\text { and PCE by } 20 \% \text {, compared with the } \\
\text { reference Si solar cell without NPs. }\end{array}$ \\
\hline [225] & $\begin{array}{l}\text { Textured silicon solar } \\
\text { cells with } \\
\text { up-conversion and } \\
\text { plasmonic scattering }\end{array}$ & $\begin{array}{l}\text { Indium } \mathrm{NPs}(7 \mathrm{~nm}) \text { in } \\
\mathrm{SiO}_{2} \text { layer }\end{array}$ & Front & $\begin{array}{l}\text { Conversion efficiency increased from } \\
14.45 \% \text { (reference cell) to } 15.43 \% \text {. }\end{array}$ \\
\hline [226] & Thin-film a-Si & $\begin{array}{l}\text { Ring-shaped Ti } \\
\text { nanoparticles }\end{array}$ & Front & $\begin{array}{l}\text { Absorption improved by } 40 \% \text { from } \\
300 \text { to } 700 \text { nm compared with the } \\
\text { reference. }\end{array}$ \\
\hline [227] & $\begin{array}{l}\text { Aluminum back } \\
\text { surface field (BSF) Si } \\
\text { solar cell }\end{array}$ & $\begin{array}{l}\text { ITO nanoparticles } \\
\text { scattered in } \mathrm{SiO}_{2} \text { layer } \\
\quad(10-90 \mathrm{~nm})\end{array}$ & Front & Efficiency improved by $33.27 \%$. \\
\hline [228] & $\begin{array}{l}\text { Silicon heterojunction } \\
\text { solar cells }\end{array}$ & $\begin{array}{l}\text { Au nanoparticles }(90 \\
\mathrm{nm})\end{array}$ & Front & $\begin{array}{c}\text { Increase in short-circuit current of } \\
15 \% .\end{array}$ \\
\hline [229] & $\begin{array}{l}\text { a-Si/c-Si heterojunction } \\
\text { solar cells }\end{array}$ & $\begin{array}{l}\text { ITO nanoparticles (75 } \\
\text { nm) }\end{array}$ & Rear & $\begin{array}{l}\text { Increase in current from } 32.8 \mathrm{~mA} / \mathrm{cm}^{2} \\
\text { to } 35.1 \mathrm{~mA} / \mathrm{cm}^{2} \text {. Increase in efficiency } \\
\text { from } 13.74 \% \text { to } 15.22 \% \text {. }\end{array}$ \\
\hline [230] & $\begin{array}{l}\text { Silicon heterojunction } \\
\text { solar cells }\end{array}$ & $\begin{array}{l}\text { Ag nanowire contacts } \\
\text { (4 } \mu \mathrm{m} \text { pitch })\end{array}$ & Front & $\begin{array}{l}\text { Increase in power conversion } \\
\text { efficiency from } 15.0 \% \text { to } 16.0 \% \text {. }\end{array}$ \\
\hline [231] & $\begin{array}{l}\text { Textured silicon solar } \\
\text { cell }\end{array}$ & $\begin{array}{l}\text { Ag-Al nanoparticles in } \\
\text { SiON matrix } \\
\text { (average } 115 \mathrm{~nm} \text { ) }\end{array}$ & Front & $\begin{array}{l}\text { Increase in photocurrent from } 26.27 \\
\mathrm{~mA} / \mathrm{cm}^{2} \text { to } 34.61 \mathrm{~mA} / \mathrm{cm}^{2}\end{array}$ \\
\hline [232] & $\begin{array}{l}\text { Crystalline silicon solar } \\
\text { cells }\end{array}$ & $\begin{array}{l}\text { TiN nanoparticles } \\
(100 \mathrm{~nm})\end{array}$ & Front & Increase in absorption of $20 \%$. \\
\hline [233] & $\begin{array}{l}\text { Aluminum BSF Si solar } \\
\text { cell }\end{array}$ & $\begin{array}{c}\mathrm{Al}_{2} \mathrm{O}_{3} / \mathrm{In} \mathrm{NPs} \\
(17.7 \mathrm{~nm}) / \mathrm{TiO}_{2} \\
\text { antireflective coating }\end{array}$ & Front & $\begin{array}{c}\text { Conversion efficiency increased from } \\
10.96 \% \text { to } 16.93 \% \text {. }\end{array}$ \\
\hline [234] & $\begin{array}{l}\text { Microcrystalline-Si } \\
\text { solar cells }\end{array}$ & $\begin{array}{l}\text { Plasmonic nanoshells } \\
\text { of silica and gold (shell } \\
\text { thickness } 30 \mathrm{~nm} \text { and } \\
\text { core radius } 50 \mathrm{~nm} \text { ) }\end{array}$ & $\begin{array}{l}\text { Embedded in } \mathrm{Si} \\
\text { active layer }\end{array}$ & Increase in photocurrent of about $21 \%$. \\
\hline [235] & $\begin{array}{l}\mathrm{ZnO} / \mathrm{p} \text {-silicon } \\
\text { heterojunction cell }\end{array}$ & $\begin{array}{l}\text { Silver nanoparticles } \\
\qquad(<10 \mathrm{~nm})\end{array}$ & Front & $\begin{array}{l}\mathrm{J}_{\mathrm{sc}} \text { increased from } 2.05 \text { to } 11.67 \\
\mathrm{~mA} / \mathrm{cm}^{2}\end{array}$ \\
\hline [236] & Thin Si solar cells & In NPs $(17.7 \mathrm{~nm})$ & Front & $\begin{array}{l}\text { Short-circuit current improved by } \\
31.88 \% \text { and conversion efficiency }\end{array}$ \\
\hline & & Ag NPs (100 nm) & Rear & improved by $32.72 \%$. \\
\hline [237] & a-Si p-i-n solar cells & $\mathrm{Au}$ NPs $(200 \mathrm{~nm})$ & Front & $\begin{array}{l}\text { Current density increased from } 9.34 \text { to } \\
10.1 \mathrm{~mA} / \mathrm{cm}^{2} \text {, and efficiency increased } \\
\text { from } 4.28 \% \text { to } 5.01 \% \text {. }\end{array}$ \\
\hline [238] & $\begin{array}{l}\text { Microcrystalline silicon } \\
\text { solar cell }\end{array}$ & Ag NPs (100 nm) & Front & Efficiency improved by $2.8 \%$. \\
\hline [239] & $\begin{array}{l}\text { Passivated emitter rear } \\
\text { totally-diffused (PERT) }\end{array}$ & $\begin{array}{l}\mathrm{Ag} \mathrm{NPs}(28 \mathrm{~nm})+\mathrm{SiO}_{2} \\
\text { and rear metal reflector }\end{array}$ & Rear & $\begin{array}{l}\text { EQE improved by } 400 \% \text {, and } \mathrm{J}_{\mathrm{sc}} \text { by } \\
16 \% .\end{array}$ \\
\hline [240] & $\begin{array}{l}\text { Bifacial crystalline } \mathrm{Si} \\
\text { solar cells }\end{array}$ & Ag NPs $(220 \mathrm{~nm})$ & Front and Rear & EQE improved by $700 \%$. \\
\hline [145] & $\begin{array}{l}\text { Passivated emitter rear } \\
\text { locally-diffused (PERL) }\end{array}$ & Ag NPs (12 nm) & Front & $\begin{array}{c}\text { EQE improved by } 700 \% \text {, and } \mathrm{J}_{\mathrm{sc}} \text { by } \\
19 \% .\end{array}$ \\
\hline [241] & $\begin{array}{l}\text { Planar crystalline } \\
\text { silicon solar cells }\end{array}$ & Ag NPs $(62 \mathrm{~nm})$ & Front & $\begin{array}{c}\text { Increase in efficiency by } 35.2 \% \text {, from } \\
11.2 \% \text { to } 15.2 \% \text {. }\end{array}$ \\
\hline [242] & $\begin{array}{l}\text { Si-Schottky barrier } \\
\text { solar cells }\end{array}$ & Ag NP (19.7 nm) & Front & $\begin{array}{c}\mathrm{J}_{\mathrm{sc}} \text { increased from } 13.7 \text { to } 19.74 \\
\left.\mathrm{~mA} / \mathrm{cm}^{2} \text { (i.e., by } 43.7 \%\right)\end{array}$ \\
\hline
\end{tabular}


Table 3. Cont.

\begin{tabular}{|c|c|c|c|c|}
\hline Ref. & Silicon Solar Cell & Plasmonic Type & Position & Achievements \\
\hline [243] & $\begin{array}{c}\text { Si-based } \\
\text { metal-insulator- } \\
\text { semiconductor (MIS) } \\
\text { Schottky junction solar } \\
\text { cells }\end{array}$ & Nanoporous Si & Front & $\begin{array}{c}\mathrm{J}_{\mathrm{sc}} \text { increased from } 0.43 \text { to } 5.52 \\
\mathrm{~mA} / \mathrm{cm}^{2} \text { (i.e., by } 92.2 \% \text { ) due to } \\
\text { reflection reduction and the } \\
\text { passivation provided by nanoporous } \\
\text { Si. }\end{array}$ \\
\hline [243] & $\begin{array}{c}\text { Si-based } \\
\text { metal-insulator- } \\
\text { semiconductor (MIS) } \\
\text { Schottky junction solar } \\
\text { cells }\end{array}$ & $\begin{array}{c}\text { Nanoporous } \mathrm{Si}+\mathrm{Ag} \\
\text { NPs }\end{array}$ & Front & $\begin{array}{c}\mathrm{J}_{\mathrm{sc}} \text { increased from } 0.43 \text { to } 8.07 \\
\mathrm{~mA} / \mathrm{cm}^{2} \text { (i.e., by } 94.6 \% \text { ) due to the } \\
\text { small size of the AgNPs, SPR effects, } \\
\text { and the improved electrical } \\
\text { conduction of the nanoPS layers. }\end{array}$ \\
\hline [185] & p-i-n a-Si:H solar Cell & $\mathrm{SiO}_{2}$ nanocone & Front & $\begin{array}{c}\mathrm{J}_{\mathrm{sc}} \text { increased from } 11.4 \text { to } 17.5 \\
\mathrm{~mA} / \mathrm{cm}^{2} \text { (i.e., by } 34.5 \% \text { ) due to } \\
\text { suppression of reflection by } \\
\text { nanodomes, which was due to the } \\
\text { formation of a graded refractive index } \\
\text { profile. }\end{array}$ \\
\hline [244] & n-i-p a-Si:H Solar Cell & $\begin{array}{l}\text { Ag back contact with } \\
\text { patterned holes ( } 225 \\
\mathrm{~nm})\end{array}$ & Rear & $\begin{array}{c}\mathrm{J}_{\mathrm{sc}} \text { increased from } 9.86 \text { to } 12.5 \\
\mathrm{~mA} / \mathrm{cm}^{2} \text { (i.e., by } 26 \% \text { ) due to the } \\
\text { periodic nanostructures on the back } \\
\text { contact of an } \mathrm{n}-\mathrm{i}-\mathrm{p} \text { a-Si:H solar cell } \\
\text { (i.e., enhancing the red-response of the } \\
\text { device). }\end{array}$ \\
\hline [245] & $\begin{array}{l}\text { Heterojunction silicon } \\
\text { solar cell }\end{array}$ & $\mathrm{SiO}_{\mathrm{x}}(70 \mathrm{~nm})$ as ARC & Front & $\begin{array}{c}\mathrm{J}_{\mathrm{sc}} \text { increased from } 34.1 \text { to } 40.5 \\
\mathrm{~mA} / \mathrm{cm}^{2} \text { (i.e., by } 16 \% \text { ) due to the } \\
\text { double-layer AR coating instead of } \\
\text { single-layer. }\end{array}$ \\
\hline
\end{tabular}

\section{Modeling the Performance of Plasmonic Solar Cells}

Modeling of plasmonic solar cells (PSC) is vital for assessing the geometrical and operating conditions for optimal optoelectronic performance. In principle, modeling of PSCs is a multiphysics problem comprising optics and electronics [246], as shown in Figure 16. Optical physics is associated with the plasmonic structure and light propagation, while electronics is associated with the physics of solar cells, which is required for investigating carrier transport and extraction.

Electric field intensity, resonance modes, absorption $(A)$, reflection $(\mathrm{R})$, transmission (T), scattering, and extinction parameters are the key indicators for optics, whereas carrier generation, transport, recombination, short circuit current, and quantum efficiency drive the solar cell, as shown in Figure 16. Interactions of plasmonic materials with solar cells have been computationally modeled using the following numerical methods: (1) finite difference time-domain (FDTD) [247], (2) finite element analysis (FEA) [248,249], (3) discontinuous Galerkin time-domain (DGTD) [143], (4) volume integral formulation [250], (5) surface integral formulation [251], (6) rigorous coupled wave analysis [252].

Multiphysics problem can be simulated using commercial software packages above numerical techniques such as FEA-based COMSOL [253], FDTD-based LUMERICAL [254] and FDTD-based ATLAS [255]. Moreover, there are also isolated packages for plasmonics (such as MNPBEM [256], MEEP [257], and PyGDM [258]) and solar cells (such as SCAPS [259], AMPS [260], PC1D/PC2D [261], and QUOKKA [262]), which can be coupled together to perform optimization problems using multiproperty optimization methods [263]. Recently, the research community has also focused on machine learning approaches for developing inverse design of photonic systems [264-266]. Mathematically, there are three standard categories for addressing functional plasmonic and photonic structures. They depend on light localization, propagation, and scattering mechanism, as shown in Figure 17 [267]. Accordingly, each light mechanism requires a dedicated numerical method to capture the physics of the process, as compared in Figure 17d. 


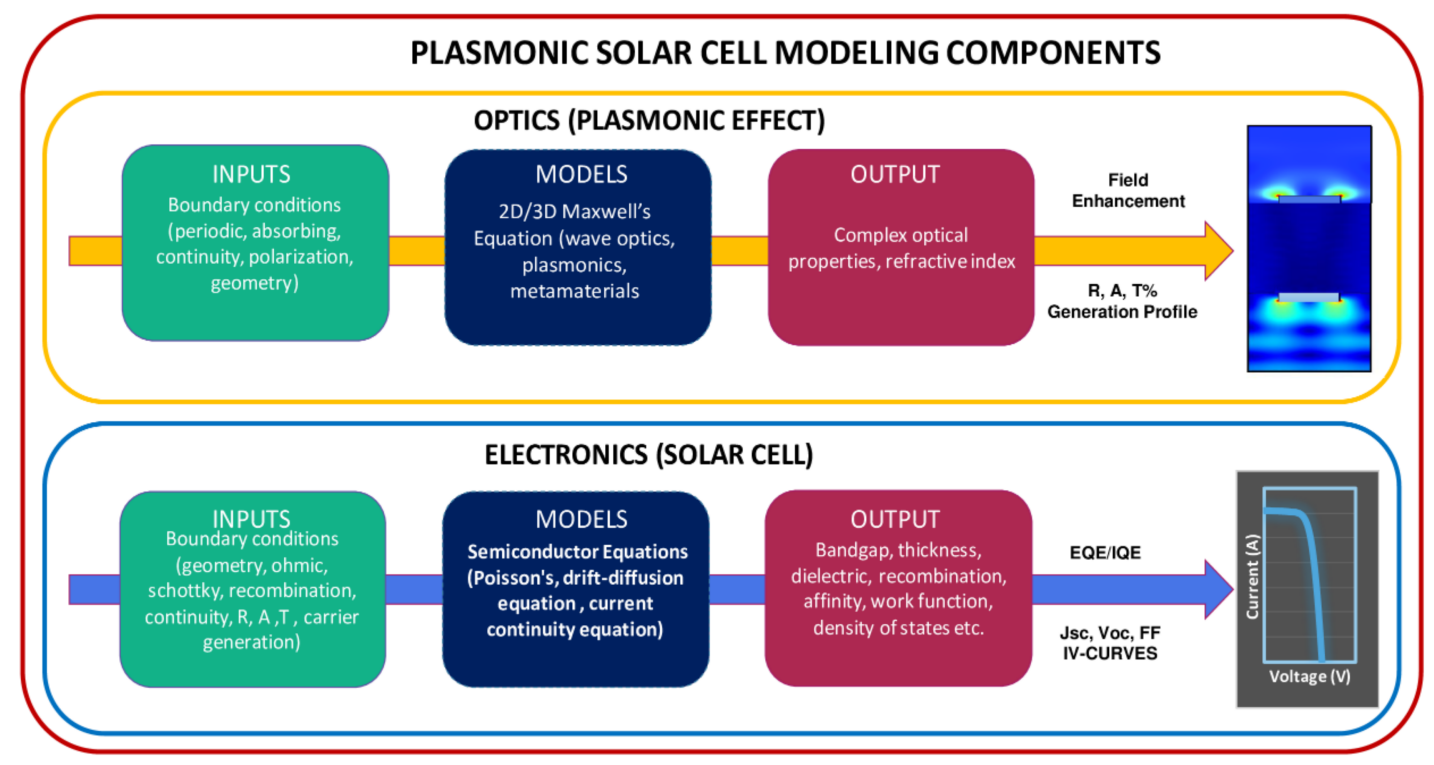

Figure 16. Plasmonic solar cell modeling components with respective input parameters, models, and output parameters required for device simulation.

a) Light Propagation
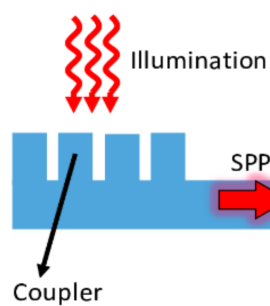

b) Light Localization

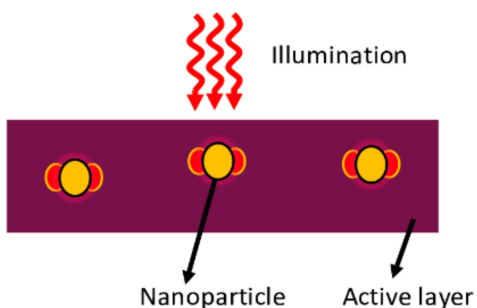

c) Light Scattering and Re-emission

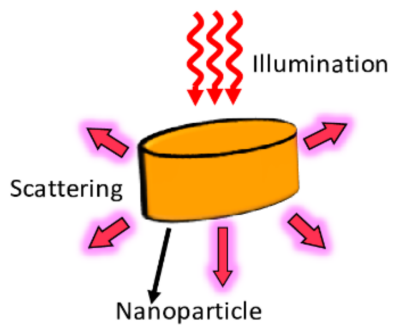

d) Summary of numerical methods and their applicability for different plasmonic devices

\begin{tabular}{|l|c|c|c|}
\hline Method & Propagation & Localization & Scattering and Re-emission \\
\hline FDTD & Good match & Good match & Can be adapted \\
\hline FEA & Fair match & Fair match & Can be adapted \\
\hline DGTD & Good match & Can be adapted & Good match \\
\hline VIF & Can be adapted & Fair match & Good match \\
\hline SIF & Can be adapted & Can be adapted & Fair match \\
\hline RCWA & Can be adapted & & \\
\hline
\end{tabular}

Figure 17. Light mechanisms involved in modeling plasmonic solar cells and comparison of modeling methods required.

\subsection{Device Designs Using Propagation of EM Waves}

It includes systems with light confinement in 1 or 2-dimension space in subdiffraction limits. It is comprised of Surface Plasmon Polaritons (SPP) in plasmonic waveguides and nanoparticle arrays as shown in Figure 17a [268]. In these systems, the main structures are the waveguide modes using their resonance frequency, electric field intensity, and losses. The coupling of SPPs with device layers is also another area important for optimization $[269,270]$. FDTD and DGTD methods for solving Maxwell's equations are best suited for simulating propagation-based plasmonic devices. They are capable of providing clear information for systems with light confinement in 1 or 2-dimensions space like decay kinetics in lossy multilayer channels and waveguides [271]. 


\subsection{Plasmonic Systems Based on Light Localization}

It confines the light in the three-dimensional region under the diffraction limit. Research is primarily focused on near-field enhancement i.e., towards light concentration using gratings on top of devices or nanoparticles in the active layer to enhance photonic absorption [272]. Figure 17b shows the schematic of a solar cell active layer equipped with nanoparticles and the associated electric field enhancement. Surface-enhanced Raman scattering and infrared absorption characterization techniques are used for measuring field confinement [273]. Nanophotonic devices relying on the localization effect include solar cells [274,275], gas sensors [276] and thermal imaging [277]. Finite Element Analysis is the preferred choice for localization problems due to its accurate prediction of resonance frequencies and near-field properties especially for irregular geometries in. DGTD and SIF provide fair results and moderately covers the key performance areas. Other methods such as VIF, FDTD, and RCWA show relatively low accuracy in assessing near-field intensity [272].

\subsection{Problems Related to Light Scattering}

It typically includes the interplay of nanostructure and electromagnetic field propagation. Nanoparticles suspended in the dielectric medium are an example of such systems. The key figure of merit for these nanoparticles are scattering, absorption and extinction coefficient [278]. For larger systems with nanostructure periodicity, the response variables become transmission, reflection, and absorption. Electron energy loss spectroscopy (EELS) utilizes the concept of inelastic scattering for assessing the atomic and electronic properties [279]. Light scattering problems are best solved by integral methods such as VIF, SIF, and RCWA. SIF methods are capable of dealing with bigger photonic systems than its counterpart VIF methods. RCWA, in contrast, shows efficient performance for periodic structure however is limited by simpler geometries [267].

\section{Summary}

The recent advancements in plasmonics for inorganic/organic PVs are summarized in this work. For the development of thin-film solar cells, advanced light-trapping techniques are key to obtain higher efficiency at lower costs. In this study, we summarize the relevant knowledge that can be extracted to unveil plasmonic processes and mechanisms. It is important to understand that electrical parameters should be studied in conjunction with photophysics to ensure that the improvement of plasmonic absorption leads to enhanced efficiency of charges and device performance. Nanostructures, when incorporated into PV devices, enhance antireflection, optical absorption, and wavelength spectrum and help in successful excitons dissociation. Moreover, it has been shown that the plasmonic effect is highly dependent on the distance between the nanostructures and the surface of the absorption layer. Furthermore, the positioning of nanostructures inside or between different layers in PV devices impacts device performance because of the different mechanisms induced. Similarly, it has been reported that broadband absorption can be obtained by different strategies such as hybrid approaches, i.e., combining different metallic or nonmetallic functional nanomaterials and nanostructures. For trapping light in the subwavelength region, nanostructures with specific sizes and geometries are anticipated to obtain the maximum possible PCE. There is much yet to explore in plasmonic nanoparticle applications in thin-film solar cells. Researchers can systematically work on the plasmonic behavior of metallic and hybrid nanoparticles of different sizes, morphologies, and densities in different layers of thin-film solar cells to obtain an optimized set of parameters for maximum light harvesting and subsequent conversion to power.

Author Contributions: A.A. has gathered the relevant and up-to-date data for preparing the manuscript by arranging the most recent publications. B.A. conceptualized the idea for preparing the review paper, participated in writing and revised the manuscript. F.E.-M. has participated in modeling and 
simulation part and give her inputs. A.M. has contributed in calculations and write up of the first version of this paper. All authors have read and agreed to the published version of the manuscript.

Funding: This research was funded by the Qatar National Research Fund (a member of the Qatar Foundation) through the NPRP grant \#NPRP11S-0117-180330.

Institutional Review Board Statement: Not Applicable.

Informed Consent Statement: Not Applicable.

Data Availability Statement: Not Applicable.

Conflicts of Interest: The authors declare no conflict of interest.

\section{Abbreviations}

$\mu \mathrm{c}-\mathrm{Si}: \mathrm{H} \quad$ Microcrystalline silicon

1D One-dimensional

2D Two-dimensional

3D Three-dimensional

Al-BSF Aluminum back surface field

AAM Anodic alumina membrane

ARC Antireflection coating

AFM Atomic force microscopy

a-Si:H Hydrogenated amorphous silicon

AZO Alumina-doped zinc oxide

CdS Cadmium sulfide

CdTe Cadmium telluride

CIGS Copper indium gallium diselenide

c-Si Crystalline silicon

CTL Charge carrier transport layer

DNA Deoxyribonucleic acid

DPN Dip-pen lithography

EBL Electron beam lithography

EM Electromagnetic

FIB Focused ion beam

LIL Laser interference lithography

LSPP Localized surface plasmon polariton

LSPR Localized surface plasmon resonance

LSP Localized surface plasmon

MCPS Microcone patterned substrate

NIL Nanoimprint lithography

NPs Nanoparticles

NSL Nanosphere lithography

OPV Organic photovoltaics

PCE Power conversion efficiency

PV Photovoltaics

QCS Quasicrystal structure

RCWA Rigorous coupled wave analysis

SCS Scattering cross-section

SECM Scanning electrochemical microscopy

SEM Scanning electron microscopy

SERS Surface enhanced Raman spectroscopy

SPP Surface plasmon polariton

SPR Surface plasmon resonance

SSD Solid-state dewetting

SThM Scanning thermal microscopy

TCO Transparent conductive oxide

TEM Transmission electron microscopy 


$\begin{array}{ll}\mathrm{TiN} & \text { Titanium nitride } \\ \mathrm{TiO}_{2} & \text { Titanium oxide } \\ \mathrm{TW} & \text { Terawatt } \\ \mathrm{UV} & \text { Ultraviolet } \\ \mathrm{ZrN} & \text { Zirconium nitride } \\ \lambda & \text { Wavelength } \\ \Lambda & \text { Periodic structure }\end{array}$

\section{References}

1. Shumkov, I. World May Hit 1.3 TW of Installed Solar in 2023-SolarPower Europe, Newyork. 2019. Available online: https: / / buildacademy.com/ (accessed on 25 January 2021).

2. Wilson, G.M.; Al-Jassim, M.; Metzger, W.K.; Glunz, S.W.; Verlinden, P.; Xiong, G.; Mansfield, L.M.; Stanbery, B.J.; Zhu, K.; Yan, Y. The 2020 photovoltaic technologies roadmap. J. Phys. D Appl. Phys. 2020, 53, 493001. [CrossRef]

3. Louwen, A.; van Sark, W.; Faaij, A.P.C.; Schropp, R.E. Re-assessment of net energy production and greenhouse gas emissions avoidance after 40 years of photovoltaics development. Nat. Commun. 2016, 7, 13728. [CrossRef] [PubMed]

4. Veith-Wolf, B.A.; Schäfer, S.; Brendel, R.; Schmidt, J. Reassessment of intrinsic lifetime limit in n-type crystalline silicon and implication on maximum solar cell efficiency. Sol. Energy Mater. Sol. Cells 2018, 186, 194-199. [CrossRef]

5. IRENA. Future of Solar Photovoltaic: Deployment, Investment, Technology, Grid Integration and Socio-Economic Aspects (A Global Energy Transformation: Paper). 2019. Available online: https://www.irena.org/-/media/Files/IRENA/Agency/ Publication/2019/Nov/IRENA_Future_of_Solar_PV_2019.pdf (accessed on 25 January 2021).

6. $\quad$ Ali, A.; Park, H.; Mall, R.; Aïssa, B.; Sanvito, S.; Bensmail, H.; Belaidi, A.; El-Mellouhi, F. Machine Learning Accelerated Recovery of the Cubic Structure in Mixed-Cation Perovskite Thin Films. Chem. Mater. 2020, 32, 2998-3006. [CrossRef]

7. Liang, M.; Ali, A.; Belaidi, A.; Hossain, M.I.; Ronan, O.; Downing, C.; Tabet, N.; Sanvito, S.; Ei-Mellouhi, F.; Nicolosi, V. Improving stability of organometallic-halide perovskite solar cells using exfoliation two-dimensional molybdenum chalcogenides. NPJ $2 D$ Mater. Appl. 2020, 4, 1-8. [CrossRef]

8. Cushing, S.K.; Wu, N. Plasmon-Enhanced Solar Energy Harvesting. Electrochem. Soc. Interface 2013, 22, 63-67. [CrossRef]

9. Amalathas, A.P.; Alkaisi, M.M. Fabrication and Replication of Periodic Nanopyramid Structures by Laser Interference Lithography and UV Nanoimprint Lithography for Solar Cells Applications. In Micro/Nanolithography; IntechOpen: London, UK, 2018. [CrossRef]

10. Kakavelakis, G.; Vangelidis, I.; Heuer-Jungemann, A.; Kanaras, A.G.; Lidorikis, E.; Stratakis, E.; Kymakis, E. Plasmonic Backscattering Effect in High-Efficient Organic Photovoltaic Devices. Adv. Energy Mater. 2015, 6, 1501640. [CrossRef]

11. Sun, C.; Wang, Z.; Wang, X.; Liu, J. A Surface Design for Enhancement of Light Trapping Efficiencies in Thin Film Silicon Solar Cells. Plasmonics 2015, 11, 1003-1010. [CrossRef]

12. In, S.; Park, N. Inverted Ultrathin Organic Solar Cells with a Quasi-Grating Structure for Efficient Carrier Collection and Dip-less Visible Optical Absorption. Sci. Rep. 2016, 6, 21784. [CrossRef]

13. Paci, B.; Kakavelakis, G.; Generosi, A.; Wright, J.; Ferrero, C.; Stratakis, E.; Kymakis, E. Improving stability of organic devices: A time/space resolved structural monitoring approach applied to plasmonic photovoltaics. Sol. Energy Mater. Sol. Cells 2017, 159, 617-624. [CrossRef]

14. Baran, D.; Ashraf, R.S.; Hanifi, D.A.; Abdelsamie, M.; Gasparini, N.; Röhr, J.A.; Holliday, S.; Wadsworth, A.; Lockett, S.; Neophytou, M.; et al. Reducing the efficiency-stability-cost gap of organic photovoltaics with highly efficient and stable small molecule acceptor ternary solar cells. Nat. Mater. 2016, 16, 363-369. [CrossRef] [PubMed]

15. Mayer, A.C.; Scully, S.R.; Hardin, B.E.; Rowell, M.W.; McGehee, M.D. Polymer-based solar cells. Mater. Today 2007, 10, 28-33. [CrossRef]

16. Falke, S.M.; Rozzi, C.A.; Brida, D.; Maiuri, M.; Amato, M.; Sommer, E.; De Sio, A.; Rubio, A.; Cerullo, G.; Molinari, E.; et al. Coherent ultrafast charge transfer in an organic photovoltaic blend. Science 2014, 344, 1001-1005. [CrossRef] [PubMed]

17. Park, H.I.; Lee, S.; Lee, J.M.; Nam, S.A.; Jeon, T.; Han, S.W.; Kim, S.O. High Performance Organic Photovoltaics with PlasmonicCoupled Metal Nanoparticle Clusters. ACS Nano 2014, 8, 10305-10312. [CrossRef]

18. Kozanoglu, D.; Apaydin, D.H.; Cirpan, A.; Esenturk, E.N. Power conversion efficiency enhancement of organic solar cells by addition of gold nanostars, nanorods, and nanospheres. Org. Electron. 2013, 14, 1720-1727. [CrossRef]

19. Iqbal, M.; Nauman, M.M.; Khan, F.U.; Abas, P.E.; Cheok, Q.; Iqbal, A.; Aissa, B. Vibration-based piezoelectric, electromagnetic, and hybrid energy harvesters for microsystems applications: A contributed review. Int. J. Energy Res. 2020, 45, 65-102. [CrossRef]

20. Liu, C.-M.; Chen, C.-M.; Su, Y.-W.; Wang, S.-M.; Wei, K.-H. The dual localized surface plasmonic effects of gold nanodots and gold nanoparticles enhance the performance of bulk heterojunction polymer solar cells. Org. Electron. 2013, 14, 2476-2483. [CrossRef]

21. Xu, W.-L.; Zeng, P.; Wu, B.; Zheng, F.; Zhu, F.; Smith, T.A.; Ghiggino, K.P.; Hao, X.-T. Effects of Processing Solvent on the Photophysics and Nanomorphology of Poly(3-butyl-thiophene) Nanowires:PCBM Blends. J. Phys. Chem. Lett. 2016, 7, 1872-1879. [CrossRef]

22. Amalathas, A.P.; Alkaisi, M.M. Nanopyramid Structures with Light Harvesting and Self-Cleaning Properties for Solar Cells. In Emerging Solar Energy Materials; IntechOpen: London, UK, 2018. [CrossRef] 
23. Amalathas, A.P.; Alkaisi, M.M. Efficient light trapping nanopyramid structures for solar cells patterned using UV nanoimprint lithography. Mater. Sci. Semicond. Process. 2016, 57, 54-58. [CrossRef]

24. Tsui, K.-H.; Lin, Q.; Chou, H.; Zhang, Q.; Fu, H.; Qi, P.; Fan, Z. Low-Cost, Flexible, and Self-Cleaning 3D Nanocone Anti-Reflection Films for High-Efficiency Photovoltaics. Adv. Mater. 2014, 26, 2805-2811. [CrossRef]

25. Amalathas, A.P.; Alkaisi, M.M. Periodic upright nanopyramid fabricated by ultraviolet curable nanoimprint lithography for thin film solar cells. Int. J. Nanotechnol. 2017, 14. [CrossRef]

26. Nechache, R.; Nicklaus, M.; Diffalah, N.; Ruediger, A.; Rosei, F. Pulsed laser deposition growth of rutile TiO2 nanowires on Silicon substrates. Appl. Surf. Sci. 2014, 313, 48-52. [CrossRef]

27. Sivasubramaniam, S.; Alkaisi, M.M. Inverted nanopyramid texturing for silicon solar cells using interference lithography. Microelectron. Eng. 2014, 119, 146-150. [CrossRef]

28. Ding, Y.; Chen, P.; Fan, Q.H.; Hou, G. Photonic Structures for Light Trapping in Thin Film Silicon Solar Cells: Design and Experiment. Coatings 2017, 7, 236. [CrossRef]

29. Khan, I.; Keshmiri, H.; Kolb, F.; Dimopoulos, T.; List-Kratochvil, E.J.W.; Dostalek, J. Multidiffractive Broadband Plasmonic Absorber. Adv. Opt. Mater. 2015, 4, 435-443. [CrossRef]

30. Palanchoke, U.; Jovanov, V.; Kurz, H.; Dewan, R.; Magnus, P.; Stiebig, H.; Knipp, D. Influence of back contact roughness on light trapping and plasmonic losses of randomly textured amorphous silicon thin film solar cells. Appl. Phys. Lett. 2013, 102, 83501. [CrossRef]

31. Macdonald, D.; Cuevas, A.; Kerr, M.; Samundsett, C.; Ruby, D.; Winderbaum, S.; Leo, A. Texturing industrial multicrystalline silicon solar cells. Sol. Energy 2004, 76, 277-283. [CrossRef]

32. Kumaravelu, G.; Alkaisi, M.; Bittar, A.; Macdonald, D.; Zhao, J. Damage studies in dry etched textured silicon surfaces. Curr. Appl. Phys. 2004, 4, 108-110. [CrossRef]

33. Wang, J.; Du, J. Plasmonic and Dielectric Metasurfaces: Design, Fabrication and Applications. Appl. Sci. 2016, 6, 239. [CrossRef]

34. Chattopadhyay, S.; Huang, Y.; Jen, Y.; Ganguly, A.; Chen, K.-H.; Chen, L. Anti-reflecting and photonic nanostructures. Mater. Sci. Eng. R Rep. 2010, 69, 1-35. [CrossRef]

35. Chiu, W.; Alkaisi, M.; Kumaravelu, G.; Blaikie, R.; Reeves, R.; Bittar, A. Sub-Wavelength Texturing for Solar Cells Using Interferometric Lithography. In Advances in Science and Technology; Trans Tech Publications Ltd.: Freienbach, Switzerland, 2006; Volume 51, pp. 115-120. [CrossRef]

36. Yu, Z.; Raman, A.; Fan, S. Fundamental limit of nanophotonic light-trapping in solar cells. Proc. Natl. Acad. Sci. USA 2010, 107, 17491-17496. [CrossRef] [PubMed]

37. Qiao, F.; Xie, Y.; He, G.; Chu, H.; Liu, W.; Chen, Z. Light trapping structures and plasmons synergistically enhance the photovoltaic performance of full-spectrum solar cells. Nanoscale 2019, 12, 1269-1280. [CrossRef] [PubMed]

38. Morawiec, S.; Crupi, I. Light trapping by plasmonic nanoparticles. In Solar Cells and Light Management; Elsevier: Amsterdam, The Netherlands, 2019; pp. 277-313. [CrossRef]

39. Hara, K.; Lertvachirapaiboon, C.; Ishikawa, R.; Ohdaira, Y.; Shinbo, K.; Kato, K.; Kaneko, F.; Baba, A. Inverted organic solar cells enhanced by grating-coupled surface plasmons and waveguide modes. Phys. Chem. Chem. Phys. 2016, 19, 2791-2796. [CrossRef] [PubMed]

40. Dang, P.T.; Nguyen, T.K.; Le, K.Q. Revisited design optimization of metallic gratings for plasmonic light-trapping enhancement in thin organic solar cells. Opt. Commun. 2017, 382, 241-245. [CrossRef]

41. Chalh, M.; Vedraine, S.; Lucas, B.; Ratier, B. Plasmonic Ag nanowire network embedded in zinc oxide nanoparticles for inverted organic solar cells electrode. Sol. Energy Mater. Sol. Cells 2016, 152, 34-41. [CrossRef]

42. Bhattacharya, S.; John, S. Photonic crystal light trapping: Beyond 30\% conversion efficiency for silicon photovoltaics. APL Photon. 2020, 5, 020902. [CrossRef]

43. Lu, X.; Rycenga, M.; Skrabalak, S.E.; Wiley, B.; Xia, Y. Chemical Synthesis of Novel Plasmonic Nanoparticles. Annu. Rev. Phys. Chem. 2009, 60, 167-192. [CrossRef]

44. Nayfeh, M.H. Optics in Nanotechnology. In Optics in Our Time; Springer: Cham, Switzerland, 2016; pp. 223-264. [CrossRef]

45. Ma, X.; Dai, Y.; Yu, L.; Huang, B. Energy transfer in plasmonic photocatalytic composites. Light Sci. Appl. 2016, 5, e16017. [CrossRef]

46. Ali, A.; Hantanasirisakul, K.; Abdala, A.; Urbankowski, P.; Zhao, M.-Q.; Anasori, B.; Gogotsi, Y.; Aïssa, B.; Mahmoud, K.A. Effect of Synthesis on Performance of MXene/Iron Oxide Anode Material for Lithium-Ion Batteries. Langmuir 2018, 34, 11325-11334. [CrossRef]

47. Wang, M.; Ye, M.; Iocozzia, J.; Lin, C.; Lin, Z. Plasmon-Mediated Solar Energy Conversion via Photocatalysis in Noble Metal/Semiconductor Composites. Adv. Sci. 2016, 3. [CrossRef]

48. Pescaglini, A.; Martín, A.; Cammi, D.; Juška, G.; Ronning, C.; Pelucchi, E.; Iacopino, D. Hot-Electron Injection in Au Nanorod-ZnO Nanowire Hybrid Device for Near-Infrared Photodetection. Nano Lett. 2014, 14, 6202-6209. [CrossRef] [PubMed]

49. Han, C.; Quan, Q.; Chen, H.-M.; Sun, Y.; Xu, Y.-J. Progressive Design of Plasmonic Metal-Semiconductor Ensemble toward Regulated Charge Flow and Improved Vis-NIR-Driven Solar-to-Chemical Conversion. Small 2017, 13. [CrossRef] [PubMed]

50. Smith, J.G.; Faucheaux, J.A.; Jain, P. Plasmon resonances for solar energy harvesting: A mechanistic outlook. Nano Today 2015, 10, 67-80. [CrossRef] 
51. Cushing, S.; Li, J.; Meng, F.; Senty, T.R.; Suri, S.; Zhi, M.; Li, M.; Bristow, A.D.; Wu, N. Photocatalytic Activity Enhanced by Plasmonic Resonant Energy Transfer from Metal to Semiconductor. J. Am. Chem. Soc. 2012, 134, 15033-15041. [CrossRef] [PubMed]

52. Christopher, P.; Xin, H.; Linic, S. Visible-light-enhanced catalytic oxidation reactions on plasmonic silver nanostructures. Nat. Chem. 2011, 3, 467-472. [CrossRef]

53. Ingram, D.B.; Linic, S. Water Splitting on Composite Plasmonic-Metal/Semiconductor Photoelectrodes: Evidence for Selective Plasmon-Induced Formation of Charge Carriers near the Semiconductor Surface. J. Am. Chem. Soc. 2011, 133, $5202-5205$. [CrossRef]

54. Zhang, N.; Han, C.; Fu, X.; Xu, Y.-J. Function-Oriented Engineering of Metal-Based Nanohybrids for Photoredox Catalysis: Exerting Plasmonic Effect and Beyond. Chem 2018, 4, 1832-1861. [CrossRef]

55. Webb, J.A.; Bardhan, R. Emerging advances in nanomedicine with engineered gold nanostructures. Nanoscale 2013, 6, 2502-2530 [CrossRef]

56. Haschke, J.; Lemerle, R.; Aissa, B.; Abdallah, A.; Kivambe, M.M.; Boccard, M.; Ballif, C. Annealing of Silicon Heterojunction Solar Cells: Interplay of Solar Cell and Indium Tin Oxide Properties. IEEE J. Photovolt. 2019, 9, 1202-1207. [CrossRef]

57. Coppens, Z.J.; Li, W.; Walker, D.G.; Valentine, J.G. Probing and Controlling Photothermal Heat Generation in Plasmonic Nanostructures. Nano Lett. 2013, 13, 1023-1028. [CrossRef]

58. Lalisse, A.; Tessier, G.; Plain, J.; Baffou, G. Quantifying the Efficiency of Plasmonic Materials for Near-Field Enhancement and Photothermal Conversion. J. Phys. Chem. C 2015, 119, 25518-25528. [CrossRef]

59. Guler, U.; Shalaev, V.M.; Boltasseva, A. Nanoparticle plasmonics: Going practical with transition metal nitrides. Mater. Today 2014 18, 227-237. [CrossRef]

60. Guler, U.; Naik, G.V.; Boltasseva, A.; Shalaev, V.M.; Kildishev, A.V. Performance analysis of nitride alternative plasmonic materials for localized surface plasmon applications. Appl. Phys. A 2012, 107, 285-291. [CrossRef]

61. Zhang, D.; Wu, H.J.; Zhou, X.; Qi, R.; Xu, L.; Guo, Y.; Liu, X. Enhanced thermal effect of plasmonic nanostructures confined in discoidal porous silicon particles. RSC Adv. 2020, 10, 30840-30847. [CrossRef]

62. $\mathrm{Wu}, \mathrm{J}$.; Gan, X. Three dimensional nanoparticle trapping enhanced by surface plasmon resonance. Opt. Express 2010, 18, 27619-27626. [CrossRef] [PubMed]

63. Braun, M.; Würger, A.; Cichos, F. Trapping of single nano-objects in dynamic temperature fields. Phys. Chem. Chem. Phys. 2014, 16, 15207-15213. [CrossRef]

64. Willets, K.A.; Van Duyne, R.P. Localized Surface Plasmon Resonance Spectroscopy and Sensing. Annu. Rev. Phys. Chem. 2007, 58, 267-297. [CrossRef]

65. Mayer, K.M.; Hafner, J.H. Localized Surface Plasmon Resonance Sensors. Chem. Rev. 2011, 111, 3828-3857. [CrossRef]

66. Zeng, S.; Baillargeat, D.; Ho, H.-P.; Yong, K.-T. Nanomaterials enhanced surface plasmon resonance for biological and chemical sensing applications. Chem. Soc. Rev. 2014, 43, 3426-3452. [CrossRef]

67. Sönnichsen, C.; Franzl, T.; Wilk, T.; von Plessen, G.; Feldmann, J.; Wilson, O.; Mulvaney, P. Drastic Reduction of Plasmon Damping in Gold Nanorods. Phys. Rev. Lett. 2002, 88, 077402. [CrossRef]

68. Baffou, G.; Berto, P.; Ureña, E.B.; Quidant, R.; Monneret, S.; Polleux, J.; Rigneault, H. Photoinduced Heating of Nanoparticle Arrays. ACS Nano 2013, 7, 6478-6488. [CrossRef]

69. Desiatov, B.; Goykhman, I.; Levy, U. Direct Temperature Mapping of Nanoscale Plasmonic Devices. Nano Lett. 2014, 14, 648-652. [CrossRef] [PubMed]

70. Yang, H.; He, L.-Q.; Hu, Y.-W.; Lu, X.; Li, G.-R.; Liu, B.; Ren, B.; Tong, Y.; Fang, P.-P. Quantitative Detection of Photothermal and Photoelectrocatalytic Effects Induced by SPR from Au@Pt Nanoparticles. Angew. Chem. Int. Ed. 2015, 54, 11462-11466. [CrossRef] [PubMed]

71. Herzog, J.; Knight, M.; Natelson, D. Thermoplasmonics: Quantifying Plasmonic Heating in Single Nanowires. Nano Lett. 2014, 14, 499-503. [CrossRef] [PubMed]

72. Jaque, D.; Vetrone, F. Luminescence nanothermometry. Nanoscale 2012, 4, 4301-4326. [CrossRef]

73. Brites, C.; Lima, P.; Silva, N.; Millán, A.; Amaral, V.; Palacio, F.; Carlos, L. A Luminescent Molecular Thermometer for Long-Term Absolute Temperature Measurements at the Nanoscale. Adv. Mater. 2010, 22, 4499-4504. [CrossRef]

74. Baffou, G.; Kreuzer, M.P.; Kulzer, F.; Quidant, R. Temperature mapping near plasmonic nanostructures using fluorescence polarization anisotropy. Opt. Express 2009, 17, 3291-3298. [CrossRef]

75. Yu, Y.; Williams, J.D.; Willets, K.A. Quantifying photothermal heating at plasmonic nanoparticles by scanning electrochemical microscopy. Faraday Discuss. 2018, 210, 29-39. [CrossRef]

76. Yu, Y.; Sundaresan, V.; Willets, K.A. Hot Carriers versus Thermal Effects: Resolving the Enhancement Mechanisms for PlasmonMediated Photoelectrochemical Reactions. J. Phys. Chem. C 2018, 122, 5040-5048. [CrossRef]

77. Baffou, G. Gold nanoparticles as nanosources of heat. Photoniques 2018, 42-47. [CrossRef]

78. Polte, J. Fundamental growth principles of colloidal metal nanoparticles-A new perspective. CrystEngComm 2015, 17, 6809-6830. [CrossRef]

79. Liška, J.; Ligmajer, F.; Pinho, N.P.V.P.; Kejik, L.; Kvapil, M.; Dvořák, P.; Horký, M.; Leitner, N.S.; Reimhult, E.; Šikola, T. Effect of deposition angle on fabrication of plasmonic gold nanocones and nanodiscs. Microelectron. Eng. 2020, 228, 111326. [CrossRef] 
80. Khoury, M. Effect of molecular weight on poly(methyl methacrylate) resolution. J. Vac. Sci. Technol. B Microelectron. Nanometer Struct. 1996, 14, 75. [CrossRef]

81. Bentouaf, A.; Mebsout, R.; Rached, H.; Amari, S.; Reshak, A.; Aïssa, B. Theoretical investigation of the structural, electronic, magnetic and elastic properties of binary cubic C15-Laves phases TbX2 ( $\mathrm{X}=\mathrm{Co}$ and Fe). J. Alloy. Compd. 2016, 689, 885-893. [CrossRef]

82. Västi, J. Fabrication of Large Area Surface Plasmonic Nanogratings. Master's Thesis, Aslto University, Espoo, Finland, 2020.

83. Khan, A. Multiple Fano resonances in bimetallic layered nanostructures. Int. Nano Lett. 2014, 4, 110. [CrossRef]

84. Luo, L.; Akinoglu, E.M.; Wu, L.; Dodge, T.; Wang, X.; Zhou, G.; Naughton, M.J.; Kempa, K.; Giersig, M. Nano-bridged nanosphere lithography. Nanotechnology 2020, 31, 245302. [CrossRef]

85. Habib, M.A.; Barkat, M.; Aissa, B.; Denidni, T.A. CA-CFAR DETECTION PERFORMANCE OF RADAR TARGETS EMBEDDED IN â"NON CENTERED CHI-2 GAMMAâ" CLUTTER. Prog. Electromagn. Res. 2008, 88, 135-148. [CrossRef]

86. Li, Z.; Song, C.; Li, Q.; Xiang, X.; Yang, H.; Wang, X.; Gao, J. Hybrid Nanostructured Antireflection Coating by Self-Assembled Nanosphere Litho. Coatings 2019, 9, 453. [CrossRef]

87. Oh, Y.; Lim, J.W.; Kim, J.G.; Wang, H.; Kang, B.-H.; Park, Y.W.; Kim, H.; Jang, Y.J.; Kim, J.; Kim, D.H.; et al. Plasmonic Periodic Nanodot Arrays via Laser Interference Lithography for Organic Photovoltaic Cells with >10\% Efficiency. ACS Nano 2016, 10, 10143-10151. [CrossRef]

88. Seo, J.-H.; Park, J.H.; Kim, S.-I.; Park, B.J.; Ma, Z.; Choi, J.; Ju, B.-K. Nanopatterning by Laser Interference Lithography: Applications to Optical Devices. J. Nanosci. Nanotechnol. 2014, 14, 1521-1532. [CrossRef]

89. Du, K.; Ding, J.; Liu, Y.; Wathuthanthri, I.; Choi, C.-H. Stencil Lithography for Scalable Micro- and Nanomanufacturing. Micromachines 2017, 8, 131. [CrossRef]

90. Shi, J.; Liu, S.; Zhang, L.; Yang, B.; Shu, L.; Yang, Y.; Ren, M.; Wang, Y.; Chen, J.; Chen, W.; et al. Smart Textile-Integrated Microelectronic Systems for Wearable Applications. Adv. Mater. 2019, 32, e1901958. [CrossRef] [PubMed]

91. Yun, H.; Kim, S.; Kim, H.; Lee, J.; McAllister, K.; Kim, J.; Pyo, S.; Kim, J.S.; Campbell, E.E.B.; Lee, W.H.; et al. Stencil Nano Lithography Based on a Nanoscale Polymer Shadow Mask: Towards Organic Nanoelectronics. Sci. Rep. 2015, 5, srep10220. [CrossRef] [PubMed]

92. Savu, V.; Xie, S.; Brugger, J. $100 \mathrm{~mm}$ dynamic stencils pattern sub-micrometre structures. Nanoscale 2011, 3, 2739-2742. [CrossRef]

93. Jung, S.; Choi, Y.-S.; Kim, J.-S. Stencil-based 3D facial relief creation from RGBD images for 3D printing. ETRI J. 2020, 42, $272-281$. [CrossRef]

94. Shahidan, M.F.S.; Song, J.; James, T.D.; Roberts, A. Multilevel nanoimprint lithography with a binary mould for plasmonic colour printing. Nanoscale Adv. 2020, 2, 2177-2184. [CrossRef]

95. Schrittwieser, S.; Haslinger, M.J.; Mitteramskogler, T.; Mühlberger, M.; Shoshi, A.; Brückl, H.; Bauch, M.; Dimopoulos, T.; Schmid, B.; Schotter, J. Multifunctional Nanostructures and Nanopocket Particles Fabricated by Nanoimprint Lithography. Nanomaterials 2019, 9, 1790. [CrossRef]

96. Barcelo, S.; Li, Z. Nanoimprint lithography for nanodevice fabrication. Nano Converg. 2016, 3, 21. [CrossRef]

97. Piner, R.D.; Zhu, J.; Xu, F.; Hong, S.; Mirkin, C.A. "Dip-Pen" Nanolithography. Science 1999, 283, 661-663. [CrossRef]

98. Braunschweig, A.B.; Huo, F.; Mirkin, C.A. Molecular printing. Nat. Chem. 2009, 1, 353-358. [CrossRef]

99. Taheri, M.L.; McGowan, S.; Nikolova, L.; Evans, J.E.; Teslich, N.; Lu, J.P.; Lagrange, T.; Rosei, F.; Siwick, B.J.; Browning, N.D. In situ laser crystallization of amorphous silicon: Controlled nanosecond studies in the dynamic transmission electron microscope. Appl. Phys. Lett. 2010, 97, 032102. [CrossRef]

100. Choi, K.H.; Ali, A.; Kim, H.C.; Hyun, M.T. Fabrication of dielectric poly (4-vinylphenol) thin films by using the electrohydrodynamic atomization technique. J. Korean Phys. Soc. 2013, 62, 269-274. [CrossRef]

101. Ali, S.; Bae, J.; Lee, C.H.; Kobayashi, N.; Shin, S.; Ali, A. Resistive switching device with highly asymmetric current-voltage characteristics: A solution to backward sneak current in passive crossbar arrays. Nanotechnology 2018, 29, 455201. [CrossRef]

102. Thompson, C.V. Solid-State Dewetting of Thin Films. Annu. Rev. Mater. Sci. 2012, 42, 399-434. [CrossRef]

103. Pandey, P.; Sui, M.; Zhang, Q.; Li, M.-Y.; Kunwar, S.; Lee, J. Systematic control of the size, density and configuration of Pt nanostructures on sapphire $\left(\begin{array}{lll}0 & 0 & 1\end{array}\right)$ by the variation of deposition amount and dwelling time. Appl. Surf. Sci. 2016, 368, 198-207. [CrossRef]

104. Choi, K.H.; Ali, A.; Rahman, A.; Mohammad, N.M.; Rahman, K.; Khan, A.; Khan, S.; Kim, D.S. Electrode configuration effects on the electrification and voltage variation in an electrostatic inkjet printing head. J. Micromech. Microeng. 2010, 20, 75033. [CrossRef]

105. Sui, M.; Li, M.-Y.; Kunwar, S.; Pandey, P.; Zhang, Q.; Lee, J. Effects of annealing temperature and duration on the morphological and optical evolution of self-assembled Pt nanostructures on c-plane sapphire. PLoS ONE 2017, 12, e0177048. [CrossRef]

106. Quan, J.; Zhang, J.; Qi, X.; Li, J.; Wang, N.; Zhu, Y. A study on the correlation between the dewetting temperature of Ag film and SERS intensity. Sci. Rep. 2017, 7, 14771. [CrossRef]

107. Qin, Y.; Kong, X.-T.; Wang, Z.; Govorov, A.O.; Kortshagen, U.R. Near-Infrared Plasmonic Copper Nanocups Fabricated by Template-Assisted Magnetron Sputtering. ACS Photon. 2017, 4, 2881-2890. [CrossRef]

108. Goetz, S.; Bauch, M.; Dimopoulos, T.; Trassl, S. Ultrathin sputter-deposited plasmonic silver nanostructures. Nanoscale Adv. 2020, 2, 869-877. [CrossRef]

109. Xu, S.; Lei, Y. Template-Assisted Fabrication of Nanostructured Arrays for Sensing Applications. ChemPlusChem 2018, 83, 741-755. [CrossRef] [PubMed] 
110. Tang, L.; Liu, Y.; Liu, G.; Chen, Q.; Li, Y.; Shi, L.; Liu, Z.; Liu, X. A Novel SERS Substrate Platform: Spatially Stacking Plasmonic Hotspots Films. Nanoscale Res. Lett. 2019, 14, 94. [CrossRef] [PubMed]

111. Solanki, C.S. Solar Photovoltaics: Fundamentals, Technologies and Applications, 3rd ed.; PHI Learning Pvt. Ltd.: New Delhi, India, 2015.

112. Amalathas, A.P.; Alkaisi, M.M. Nanostructures for Light Trapping in Thin Film Solar Cells. Micromachines 2019, 10, 619. [CrossRef] [PubMed]

113. Santbergen, R.; Temple, T.L.; Liang, R.; Smets, A.H.M.; Swaaij, R.A.C.M.M.V.; Zeman, M. Application of plasmonic silver island films in thin-film silicon solar cells. J. Opt. 2012, 14. [CrossRef]

114. Gee, J.M. The effect of parasitic absorption losses on light trapping in thin silicon solar cells. In Proceedings of the Conference Record of the Twentieth IEEE Photovoltaic Specialists Conference IEEE, Las Vegas, NV, USA, 26-30 September 1988; pp. 549-554.

115. Xue, M.; Li, L.; de Villers, B.J.T.; Shen, H.; Zhu, J.; Yu, Z.; Stieg, A.Z.; Pei, Q.; Schwartz, B.J.; Wang, K.L. Charge-carrier dynamics in hybrid plasmonic organic solar cells with Ag nanoparticles. Appl. Phys. Lett. 2011, 98, 253302. [CrossRef]

116. Du, P.; Jing, P.; Li, D.; Cao, Y.; Liu, Z.; Sun, Z. Plasmonic Ag@Oxide Nanoprisms for Enhanced Performance of Organic Solar Cells. Small 2015, 11, 2454-2462. [CrossRef]

117. Mandoc, M.M.; Veurman, W.; Koster, L.J.A.; de Boer, B.; Blom, P.W.M. Origin of the Reduced Fill Factor and Photocurrent in MDMO-PPV:PCNEPV All-Polymer Solar Cells. Adv. Funct. Mater. 2007, 17, 2167-2173. [CrossRef]

118. Jeong, S.; Garnett, E.; Wang, S.; Yu, Z.; Fan, S.; Brongersma, M.L.; McGehee, M.D.; Cui, Y. Hybrid Silicon Nanocone-Polymer Solar Cells. Nano Lett. 2012, 12, 2971-2976. [CrossRef]

119. Bordjiba, T.; Mohamedi, M.; Dao, L.H.; Aissa, B.; El Khakani, M.A. Enhanced physical and electrochemical properties of nanostructured carbon nanotubes coated microfibrous carbon paper. Chem. Phys. Lett. 2007, 441, 88-93. [CrossRef]

120. Wang, B.; Leu, P.W. Enhanced absorption in silicon nanocone arrays for photovoltaics. Nanotechnology 2012, 23, 194003. [CrossRef]

121. Lu, Y.; Lal, A. High-Efficiency Ordered Silicon Nano-Conical-Frustum Array Solar Cells by Self-Powered Parallel Electron Lithography. Nano Lett. 2010, 10, 4651-4656. [CrossRef] [PubMed]

122. Tsai, D.-S.; Lin, C.-A.; Lien, W.-C.; Chang, H.-C.; Wang, Y.-L.; He, J.-H. Ultra-High-Responsivity Broadband Detection of Si MetalSemiconductor-Metal Schottky Photodetectors Improved by ZnO Nanorod Arrays. ACS Nano 2011, 5, 7748-7753. [CrossRef] [PubMed]

123. Lin, Y.-R.; Wang, H.-P.; Lin, C.-A.; He, J.-H. Surface profile-controlled close-packed Si nanorod arrays for self-cleaning antireflection coatings. J. Appl. Phys. 2009, 106, 114310. [CrossRef] [PubMed]

124. Fan, Z.; Razavi, H.; Do, J.-W.; Moriwaki, A.; Ergen, O.; Chueh, Y.-L.; Leu, P.; Ho, J.; Takahashi, T.; Reichertz, L.A.; et al. Three-dimensional nanopillar-array photovoltaics on low-cost and flexible substrates. Nat. Mater. 2009, 8, 648-653. [CrossRef] [PubMed]

125. Kapadia, R.; Fan, Z.; Takei, K.; Javey, A. Nanopillar photovoltaics: Materials, processes, and devices. Nano Energy 2011, 1, 132-144. [CrossRef]

126. Wu, J.; Wang, Y. Optical Absorption and Thermal Effects of Plasmonic Nanostructures. Nanoplasmonics 2017. [CrossRef]

127. Han, S.E.; Chen, G. Optical Absorption Enhancement in Silicon Nanohole Arrays for Solar Photovoltaics. Nano Lett. 2010, 10, 1012-1015. [CrossRef]

128. Leung, S.-F.; Yu, M.; Lin, Q.; Kwon, K.; Ching, K.L.; Gu, L.; Yu, K.; Fan, Z. Efficient Photon Capturing with Ordered ThreeDimensional Nanowell Arrays. Nano Lett. 2012, 12, 3682-3689. [CrossRef]

129. Amalathas, A.P.; Alkaisi, M.M. Enhancing the performance of solar cells with inverted nanopyramid structures fabricated by UV nanoimprint lithography. In Proceedings of the 2016 IEEE 43rd Photovoltaic Specialists Conference (PVSC), Portland, OR, USA, 5-10 June 2016; pp. 346-349. [CrossRef]

130. Li, G.; Li, H.; Ho, J.Y.L.; Wong, M.; Kwok, H.S. Nanopyramid Structure for Ultrathin c-Si Tandem Solar Cells. Nano Lett. 2014, 14, 2563-2568. [CrossRef]

131. Mavrokefalos, A.; Han, S.E.; Yerci, S.; Branham, M.S.; Chen, G. Efficient Light Trapping in Inverted Nanopyramid Thin Crystalline Silicon Membranes for Solar Cell Applications. Nano Lett. 2012, 12, 2792-2796. [CrossRef]

132. Yao, Y.; Yao, J.; Narasimhan, V.; Ruan, Z.; Xie, C.; Fan, S.; Cui, Y. Broadband light management using low-Q whispering gallery modes in spherical nanoshells. Nat. Commun. 2012, 3, 664. [CrossRef]

133. Grandidier, J.; Callahan, D.M.; Munday, J.N.; Atwater, H.A. Light Absorption Enhancement in Thin-Film Solar Cells Using Whispering Gallery Modes in Dielectric Nanospheres. Adv. Mater. 2011, 23, 1272-1276. [CrossRef] [PubMed]

134. Cao, L.; White, J.S.; Park, J.-S.; Schuller, J.A.; Clemens, B.M.; Brongersma, M.L. Engineering light absorption in semiconductor nanowire devices. Nat. Mater. 2009, 8, 643-647. [CrossRef] [PubMed]

135. Naughton, M.J.; Kempa, K.; Ren, Z.F.; Gao, Y.; Rybczynski, J.; Argenti, N.; Gao, W.; Wang, Y.; Peng, Y.; Naughton, J.R.; et al. Efficient nanocoax-based solar cells. Phys. Status solidi (RRL)-Rapid Res. Lett. 2010, 4, 181-183. [CrossRef]

136. Liu, S.; Jiang, R.; You, P.; Zhu, X.; Wang, J.; Yan, F. Au/Ag core-shell nanocuboids for high-efficiency organic solar cells with broadband plasmonic enhancement. Energy Environ. Sci. 2016, 9, 898-905. [CrossRef]

137. Hergert Wolfram, W.T. The Mie Theory: Basics and Applications; Springer: Berlin/Heidelberg, Germany, 2012.

138. Atwater, H.A.; Polman, A. Plasmonics for improved photovoltaic devices. Nat. Mater. 2010, 9, 205-213. [CrossRef]

139. Deceglie, M.G.; Ferry, V.E.; Alivisatos, A.P.; Atwater, H.A.; Alivisatos, P. Design of Nanostructured Solar Cells Using Coupled Optical and Electrical Modeling. Nano Lett. 2012, 12, 2894-2900. [CrossRef] 
140. Le Borgne, V.; Castrucci, P.; Del Gobbo, S.; Scarselli, M.; De Crescenzi, M.; Mohamedi, M.; El Khakani, M.A. Enhanced photocurrent generation from UV-laser-synthesized-single-wall-carbon-nanotubes/n-silicon hybrid planar devices. Appl. Phys. Lett. 2010, 97, 193105. [CrossRef]

141. Morawiec, S.; Mendes, M.J.; Filonovich, S.A.; Mateus, T.; Mirabella, S.; Águas, H.; Ferreira, I.; Simone, F.; Fortunato, E.; Martins, R.; et al. Broadband photocurrent enhancement in a-Si:H solar cells with plasmonic back reflectors. Opt. Express 2014, 22, A1059-A1070. [CrossRef]

142. Yao, K.; Salvador, M.; Chueh, C.-C.; Xin, X.-K.; Xu, Y.-X.; Dequilettes, D.W.; Hu, T.; Chen, Y.; Ginger, D.S.; Jen, A.K.-Y. A General Route to Enhance Polymer Solar Cell Performance using Plasmonic Nanoprisms. Adv. Energy Mater. 2014, 4. [CrossRef]

143. Moeferdt, M.; Kiel, T.; Sproll, T.; Intravaia, F.; Busch, K. Plasmonic modes in nanowire dimers: A study based on the hydrodynamic Drude model including nonlocal and nonlinear effects. Phys. Rev. B 2018, 97, 075431. [CrossRef]

144. Maier, S.A. Plasmonics: Fundamentals and Applications, 1st ed.; Springer Science \& Business Media: New York, NY, USA, 2007.

145. Pillai, S.; Catchpole, K.; Trupke, T.; Green, M. Surface plasmon enhanced silicon solar cells. J. Appl. Phys. 2007, 101, 093105. [CrossRef]

146. Wang, X.; Gogol, P.; Cambril, E.; Palpant, B. Near- and Far-Field Effects on the Plasmon Coupling in Gold Nanoparticle Arrays. J. Phys. Chem. C 2012, 116, 24741-24747. [CrossRef]

147. Lindquist, N.C.; Nagpal, P.; McPeak, K.M.; Norris, D.J.; Oh, S.-H. Engineering metallic nanostructures for plasmonics and nanophotonics. Rep. Prog. Phys. 2012, 75, 036501. [CrossRef]

148. Catchpole, K.; Polman, A. Design principles for particle plasmon enhanced solar cells. Appl. Phys. Lett. 2008, $93,191113$. [CrossRef]

149. Catchpole, K.R.; Polman, A. Plasmonic solar cells. Opt. Express 2008, 16, 21793-21800. [CrossRef] [PubMed]

150. Pillai, S.; Green, M. Plasmonics for photovoltaic applications. Sol. Energy Mater. Sol. Cells 2010, 94, 1481-1486. [CrossRef]

151. Beck, F.; Polman, A.; Catchpole, K. Tunable light trapping for solar cells using localized surface plasmons. J. Appl. Phys. 2009, 105, 114310. [CrossRef]

152. Xu, G.; Tazawa, M.; Jin, P.; Nakao, S.; Yoshimura, K. Wavelength tuning of surface plasmon resonance using dielectric layers on silver island films. Appl. Phys. Lett. 2003, 82, 3811-3813. [CrossRef]

153. Mertens, H.G.; Verhoeven, J.W.; Polman, A.; Tichelaar, F.D. Infrared surface plasmons in two-dimensional silver nanoparticle arrays in silicon. Appl. Phys. Lett. 2004, 85, 1317-1319. [CrossRef]

154. Saravanan, S. Optical pathlength enhancement in ultrathin silicon solar cell using decorated silver nanoparticles on aluminium grating. Nanosyst. Phys. Chem. Math. 2020, 11, 86-91. [CrossRef]

155. Zhang, Y.; Ouyang, Z.; Stokes, N.; Jia, B.; Shi, Z.; Gu, M. Low cost and high performance Al nanoparticles for broadband light trapping in Si wafer solar cells. Appl. Phys. Lett. 2012, 100, 151101. [CrossRef]

156. Uhrenfeldt, C.; Villesen, T.F.; Têtu, A.; Johansen, B.; Larsen, A.N. Broadband photocurrent enhancement and light-trapping in thin film Si solar cells with periodic Al nanoparticle arrays on the front. Opt. Express 2015, 23, A525-A538. [CrossRef] [PubMed]

157. Hlaing, M.; Gebear-Eigzabher, B.; Roa, A.; Marcano, A.; Radu, D.; Lai, C.-Y. Absorption and scattering cross-section extinction values of silver nanoparticles. Opt. Mater. 2016, 58, 439-444. [CrossRef]

158. Paszkiewicz-Gawron, M.; Gołąbiewska, A.; Rajski, S.; Kowal, E.; Sajdak, A.; Zaleska-Medynska, A. Synthesis and Characterization of Monometallic (Ag, Cu) and Bimetallic Ag-Cu Particles for Antibacterial and Antifungal Applications. J. Nanomater. 2016, 2016, 1-11. [CrossRef]

159. Fathi, F.; Rashidi, M.R.; Omidi, Y. Ultra-sensitive detection by metal nanoparticles-mediated enhanced SPR biosensors. Talanta 2019, 192, 118-127. [CrossRef]

160. Rehman, Q.; Khan, A.D.; Khan, A.D.; Noman, M.; Ali, H.; Rauf, A.; Ahmad, M.S. Super absorption of solar energy using a plasmonic nanoparticle based CdTe solar cell. RSC Adv. 2019, 9, 34207-34213. [CrossRef]

161. Ferry, V.; Sweatlock, L.A.; Pacifici, D.; Atwater, H.A. Plasmonic Nanostructure Design for Efficient Light Coupling into Solar Cells. Nano Lett. 2008, 8, 4391-4397. [CrossRef]

162. Jain, S.; Paliwal, A.; Gupta, V.; Tomar, M. Plasmon-Assisted Crystalline Silicon Solar Cell with TiO2 as Anti-Reflective Coating. Plasmonics 2020, 15, 1091-1101. [CrossRef]

163. Landy, N.I.; Sajuyigbe, S.; Mock, J.J.; Smith, D.R.; Padilla, W.J. Perfect Metamaterial Absorber. Phys. Rev. Lett. 2008, 100, 207402. [CrossRef]

164. Khan, A.D.; Amin, M. Tunable Salisbury Screen Absorber Using Square Lattice of Plasmonic Nanodisk. Plasmonics 2017, 12, 257-262. [CrossRef]

165. Ullah, H.; Khan, A.; Noman, M.; Rehman, A.U. Novel Multi-Broadband Plasmonic Absorber Based on a Metal-Dielectric-Metal Square Ring Array. Plasmonics 2018, 13, 591-597. [CrossRef]

166. Liu, X.; Starr, T.; Starr, A.F.; Padilla, W.J. Infrared Spatial and Frequency Selective Metamaterial with Near-Unity Absorbance. Phys. Rev. Lett. 2010, 104, 207403. [CrossRef] [PubMed]

167. Muhammad, N.; Khan, A. Tunable Fano Resonances and Electromagnetically Induced Transparency in All-Dielectric Holey Block. Plasmonics 2015, 10, 1687-1693. [CrossRef]

168. Khan, A.; Amin, M.; Ali, A.; Khan, S.D.; Khan, R. Multiple higher-order Fano resonances in plasmonic hollow cylindrical nanodimer. Appl. Phys. A 2015, 120, 641-649. [CrossRef] 
169. Cheng, C.; Gustavsen, K.R.; Wang, K. Plasmon-induced visible light absorption arising from edge-interfaces of titanium-oxides nanocomposites. Opt. Mater. 2021, 113, 110847. [CrossRef]

170. Hungerford, C.D.; Fauchet, P.M. Design of a plasmonic back reflector using Ag nanoparticles with a mirror support for an a-Si:H solar cell. AIP Adv. 2017, 7, 75004. [CrossRef]

171. Crudgington, L.; Rahman, T.; Boden, S. Development of amorphous silicon solar cells with plasmonic light scattering. Vacuum 2017, 139, 164-172. [CrossRef]

172. Sun, C.; Su, J.; Wang, X. A Design of Thin Film Silicon Solar Cells Based on Silver Nanoparticle Arrays. Plasmonics 2015, 10, 633-641. [CrossRef]

173. Desta, D.; Rizzoli, R.; Summonte, C.; Pereira, R.N.; Larsen, A.N.; Balling, P.; Ram, S.K. Nanomolded buried light-scattering (BLiS) back-reflectors using dielectric nanoparticles for light harvesting in thin-film silicon solar cells. EPJ Photovolt. 2020, 11, 2. [CrossRef]

174. Eisele, C.; Nebel, C.E.; Stutzmann, M. Periodic light coupler gratings in amorphous thin film solar cells. J. Appl. Phys. 2001, 89, 7722-7726. [CrossRef]

175. Haase, C.; Stiebig, H. Optical properties of thin-film silicon solar cells with grating couplers. Prog. Photovolt. Res. Appl. 2006, 14, 629-641. [CrossRef]

176. Aissa, B.; Hamoudi, Z.; Takahashi, H.; Tohji, K.; Mohamedi, M.; El Khakani, M.A. Carbon nanohorns-coated microfibers for use as free-standing electrodes for electrochemical power sources. Electrochem. Commun. 2009, 11, 862-866. [CrossRef]

177. Sai, H.; Fujiwara, H.; Kondo, M.; Kanamori, Y. Enhancement of light trapping in thin-film hydrogenated microcrystalline Si solar cells using back reflectors with self-ordered dimple pattern. Appl. Phys. Lett. 2008, 93, 143501. [CrossRef]

178. Wang, K.X.; Yu, Z.; Liu, V.; Cui, Y.; Fan, S. Absorption Enhancement in Ultrathin Crystalline Silicon Solar Cells with Antireflection and Light-Trapping Nanocone Gratings. Nano Lett. 2012, 12, 1616-1619. [CrossRef]

179. Prajapati, A.; Chauhan, A.; Keizman, D.; Shalev, G. Approaching the Yablonovitch limit with free-floating arrays of subwavelength trumpet non-imaging light concentrators driven by extraordinary low transmission. Nanoscale 2019, 11, 3681-3688. [CrossRef]

180. Putnam, M.C.; Turner-Evans, D.B.; Kelzenberg, M.D.; Boettcher, S.W.; Lewis, N.S.; Atwater, H.A. $10 \mu$ m minority-carrier diffusion lengths in Si wires synthesized by Cu-catalyzed vapor-liquid-solid growth. Appl. Phys. Lett. 2009, 95, 163116. [CrossRef]

181. Tsakalakos, L.; Shih, M.-Y.; Leboeuf, S.F.; Pietrzykowski, M.; Sulima, O.V.; Rand, J.; Davuluru, A.; Rapol, U.; Balch, J.; Codella, P.J.; et al. Strong broadband optical absorption in silicon nanowire films. J. Nanophoton. 2007, 1, 013552. [CrossRef]

182. Callahan, D.M.; Munday, J.N.; Atwater, H.A. Solar Cell Light Trapping beyond the Ray Optic Limit. Nano Lett. 2012, 12, 214-218. [CrossRef]

183. Wang, P.; Menon, R. Optimization of generalized dielectric nanostructures for enhanced light trapping in thin-film photovoltaics via boosting the local density of optical states. Opt. Express 2013, 22, A99-A110. [CrossRef]

184. Meng, X.; Depauw, V.; Gomard, G.; El Daif, O.; Trompoukis, C.; Drouard, E.; Jamois, C.; Fave, A.; Dross, F.; Gordon, I.; et al. Design, fabrication and optical characterization of photonic crystal assisted thin film monocrystalline-silicon solar cells. Opt. Express 2012, 20, A465-A475. [CrossRef] [PubMed]

185. Zhu, J.; Hsu, C.-M.; Yu, Z.; Fan, S.; Cui, Y. Nanodome Solar Cells with Efficient Light Management and Self-Cleaning. Nano Lett. 2009, 10, 1979-1984. [CrossRef]

186. Chutinan, A.; Kherani, N.P.; Zukotynski, S. High-efficiency photonic crystal solar cell architecture. Opt. Express 2009, 17, 8871-8878. [CrossRef] [PubMed]

187. Kelzenberg, M.D.; Turner-Evans, D.B.; Kayes, B.M.; Filler, M.A.; Putnam, M.C.; Lewis, A.N.S.; Atwater, H.A. Photovoltaic Measurements in Single-Nanowire Silicon Solar Cells. Nano Lett. 2008, 8, 710-714. [CrossRef]

188. Aïssa, B.; Nedil, M.; Kroeger, J.; Ali, A.; Isaifan, R.; Essehli, R.; A Mahmoud, K. Graphene nanoplatelet doping of P3HT:PCBM photoactive layer of bulk heterojunction organic solar cells for enhancing performance. Nanotechnology 2018, 29, 105405. [CrossRef] [PubMed]

189. Wang, D.H.; Park, K.H.; Seo, J.H.; Seifter, J.; Jeon, J.H.; Kim, J.K.; Park, J.H.; Park, O.O.; Heeger, A.J. Enhanced Power Conversion Efficiency in PCDTBT/PC70BM Bulk Heterojunction Photovoltaic Devices with Embedded Silver Nanoparticle Clusters. Adv. Energy Mater. 2011, 1, 766-770. [CrossRef]

190. Wang, D.H.; Kim, D.Y.; Choi, K.W.; Seo, J.H.; Im, S.H.; Park, J.H.; Park, O.O.; Heeger, A.J. Enhancement of Donor-Acceptor Polymer Bulk Heterojunction Solar Cell Power Conversion Efficiencies by Addition of Au Nanoparticles. Angew. Chem. Int. Ed. 2011, 50, 5519-5523. [CrossRef]

191. Kim, W.; Cha, B.G.; Kim, J.K.; Kang, W.; Kim, E.; Ahn, T.K.; Wang, D.H.; Du, Q.G.; Cho, J.H.; Kim, J.; et al. Tailoring Dispersion and Aggregation of Au Nanoparticles in the BHJ Layer of Polymer Solar Cells: Plasmon Effects versus Electrical Effects. ChemSusChem 2014, 7, 3452-3458. [CrossRef]

192. Gollu, S.R.; Sharma, R.; Srinivas, G.; Kundu, S.; Gupta, D. Incorporation of silver and gold nanostructures for performance improvement in P3HT: PCBM inverted solar cell with $\mathrm{rGO} / \mathrm{ZnO}$ nanocomposite as an electron transport layer. Org. Electron. 2016, 29, 79-87. [CrossRef]

193. Sygletou, M.; Tzourmpakis, P.; Petridis, C.; Konios, D.; Fotakis, C.; Kymakis, E.; Stratakis, E. Laser induced nucleation of plasmonic nanoparticles on two-dimensional nanosheets for organic photovoltaics. J. Mater. Chem. A 2015, 4, 1020-1027. [CrossRef] 
194. Ren, X.; Cheng, J.; Zhang, S.; Li, X.; Rao, T.; Huo, L.; Hou, J.; Choy, W.C.H. High Efficiency Organic Solar Cells Achieved by the Simultaneous Plasmon-Optical and Plasmon-Electrical Effects from Plasmonic Asymmetric Modes of Gold Nanostars. Small 2016, 12, 5200-5207. [CrossRef] [PubMed]

195. Zhang, R.; Zhou, Y.; Peng, L.; Li, X.; Chen, S.; Feng, X.; Guan, Y.; Huang, W. Influence of SiO2 shell thickness on power conversion efficiency in plasmonic polymer solar cells with Au nanorod@SiO2 core-shell structures. Sci. Rep. 2016, 6, 25036. [CrossRef] [PubMed]

196. Hu, T.; Li, L.; Xiao, S.; Yuan, K.; Yang, H.; Chen, L.; Chen, Y. In situ implanting carbon nanotube-gold nanoparticles into ZnO as efficient nanohybrid cathode buffer layer for polymer solar cells. Org. Electron. 2016, 38, 350-356. [CrossRef]

197. Li, S.; Li, Z.; Zhang, X.; Zhang, Z.; Liu, C.; Shen, L.; Guo, W.; Ruan, S. Performance enhancement of organic photovoltaic devices enabled by Au nanoarrows inducing surface plasmonic resonance effect. Phys. Chem. Chem. Phys. 2016, 18, 24285-24289. [CrossRef]

198. Chi, D.; Lu, S.; Xu, R.; Liu, K.; Cao, D.; Wen, L.; Mi, Y.; Wang, Z.; Lei, Y.; Qu, S.; et al. Fully understanding the positive roles of plasmonic nanoparticles in ameliorating the efficiency of organic solar cells. Nanoscale 2015, 7, 15251-15257. [CrossRef]

199. Malureanu, R.; Lavrinenko, A. Ultra-thin films for plasmonics: A technology overview. Nanotechnol. Rev. 2015, 4. [CrossRef]

200. Shen, P.; Liu, Y.; Long, Y.; Shen, L.; Kang, B. High-Performance Polymer Solar Cells Enabled by Copper Nanoparticles-Induced Plasmon Resonance Enhancement. J. Phys. Chem. C 2016, 120, 8900-8906. [CrossRef]

201. Yao, M.; Shen, P.; Liu, Y.; Chen, B.; Guo, W.; Ruan, S.; Shen, L. Performance Improvement of Polymer Solar Cells by SurfaceEnergy-Induced Dual Plasmon Resonance. ACS Appl. Mater. Interfaces 2016, 8, 6183-6189. [CrossRef]

202. Choi, M.; Kang, G.; Shin, D.; Barange, N.; Lee, C.-W.; Ko, D.-H.; Kim, K. Lithography-Free Broadband Ultrathin-Film Absorbers with Gap-Plasmon Resonance for Organic Photovoltaics. ACS Appl. Mater. Interfaces 2016, 8, 12997-13008. [CrossRef]

203. Yao, K.; Jiao, H.; Xu, Y.-X.; He, Q.; Li, F.; Wang, X. Nano-bio hybrids of plasmonic metals/photosynthetic proteins for broad-band light absorption enhancement in organic solar cells. J. Mater. Chem. A 2016, 4, 13400-13406. [CrossRef]

204. Nagamani, S.; Kumarasamy, G.; Song, M.; Kim, C.S.; Kim, D.-H.; Ryu, S.Y.; Kang, J.-W.; Jin, S.-H. Optical absorption and electrical properties of enhanced efficiency in organic solar cells as interfacial layer with Au NPs. Synth. Met. 2016, 217, 117-122. [CrossRef]

205. Yang, Y.; Qing, J.; Ou, J.; Lin, X.; Yuan, Z.; Yu, D.; Zhou, X.; Chen, X. Rational design of metallic nanowire-based plasmonic architectures for efficient inverted polymer solar cells. Sol. Energy 2015, 122, 231-238. [CrossRef]

206. Ali, A.; Said, D.; Khayyat, M.; Boustimi, M.; Seoudi, R. Improving the efficiency of the organic solar cell (CuPc/C60) via PEDOT: PSS as a photoconductor layer doped by silver nanoparticles. Results Phys. 2020, 16, 102819. [CrossRef]

207. Ali, A.; Kang, J.H.; Seo, J.H.; Walker, B. Effect of Plasmonic Ag Nanoparticles on the Performance of Inverted Perovskite Solar Cells. Adv. Eng. Mater. 2020, 22. [CrossRef]

208. Chen, L.-C.; Tien, C.-H.; Lee, K.-L.; Kao, Y.-T. Efficiency Improvement of MAPbI3 Perovskite Solar Cells Based on a CsPbBr3 Quantum Dot/Au Nanoparticle Composite Plasmonic Light-Harvesting Layer. Energies 2020, 13, 1471. [CrossRef]

209. Kim, G.M.; Tatsuma, T. Photocurrent Enhancement of Perovskite Solar Cells at the Absorption Edge by Electrode-Coupled Plasmons of Silver Nanocubes. J. Phys. Chem. C 2017, 121, 11693-11699. [CrossRef]

210. Mohsen, A.A.; Zahran, M.; Habib, S.E.D.; Allam, N.K. Refractory plasmonics enabling 20\% efficient lead-free perovskite solar cells. Sci. Rep. 2020, 10, 1-12. [CrossRef]

211. Zhang, W.; Saliba, M.; Stranks, S.D.; Sun, Y.; Shi, X.; Wiesner, U.; Snaith, H.J. Enhancement of Perovskite-Based Solar Cells Employing Core-Shell Metal Nanoparticles. Nano Lett. 2013, 13, 4505-4510. [CrossRef]

212. Saliba, M.; Zhang, W.; Burlakov, V.M.; Stranks, S.D.; Sun, Y.; Ball, J.M.; Johnston, M.B.; Goriely, A.; Wiesner, U.; Snaith, H.J Plasmonic-Induced Photon Recycling in Metal Halide Perovskite Solar Cells. Adv. Funct. Mater. 2015, 25, 5038-5046. [CrossRef]

213. Lu, Z.; Pan, X.; Ma, Y.; Li, Y.; Zheng, L.; Zhang, D.; Xu, Q.; Chen, Z.; Wang, S.; Qu, B.; et al. Plasmonic-enhanced perovskite solar cells using alloy popcorn nanoparticles. RSC Adv. 2015, 5, 11175-11179. [CrossRef]

214. Liu, S.; Liang, L.; Meng, L.; Tian, X.; Zhang, Z.; Yu, Y.; Lan, Z.; Wu, J.; Zhang, J.; Gao, P. Synergy of Plasmonic Silver Nanorod and Water for Enhanced Planar Perovskite Photovoltaic Devices. Sol. RRL 2019, 4. [CrossRef]

215. Fan, R.; Wang, L.; Chen, Y.; Zheng, G.; Li, L.; Li, Z.; Zhou, H. Tailored Au@TiO2 nanostructures for the plasmonic effect in planar perovskite solar cells. J. Mater. Chem. A 2017, 5, 12034-12042. [CrossRef]

216. Ghosh, J.; Giri, P.K. Effect of plasmonic metal nanoparticles on the performance of air processed inverted perovskite solar cells. AIP Conf. Proc. 2019, 2082, 050004. [CrossRef]

217. Hu, Z.; García-Martín, J.M.; Li, Y.; Billot, L.; Sun, B.; Fresno, F.; Garcia-Martin, A.; González, M.U.; Aigouy, L.; Chen, Z. TiO2 Nanocolumn Arrays for More Efficient and Stable Perovskite Solar Cells. ACS Appl. Mater. Interfaces 2020, 12, 5979-5989. [CrossRef] [PubMed]

218. Luo, Q.; Zhang, C.; Deng, X.; Zhu, H.; Li, Z.; Wang, Z.; Chen, X.; Huang, S. Plasmonic Effects of Metallic Nanoparticles on Enhancing Performance of Perovskite Solar Cells. ACS Appl. Mater. Interfaces 2017, 9, 34821-34832. [CrossRef] [PubMed]

219. Ginting, R.T.; Kaur, S.; Lim, D.-K.; Kim, J.-M.; Lee, J.H.; Lee, S.H.; Kang, J.-W. Plasmonic Effect of Gold Nanostars in Highly Efficient Organic and Perovskite Solar Cells. ACS Appl. Mater. Interfaces 2017, 9, 36111-36118. [CrossRef]

220. Irandoost, R.; Soleimani-Amiri, S. Design and analysis of high efficiency perovskite solar cell with ZnO nanorods and plasmonic nanoparticles. Optik 2019, 202, 163598. [CrossRef]

221. Kesavan, A.V.; Rao, A.D.; Ramamurthy, P.C.; Kesavan, A.V.; Rao, A.D.; Ramamurthy, P.C. Tailoring optoelectronic properties of $\mathrm{CH} 3 \mathrm{NH} 3 \mathrm{PbI} 3$ perovskite photovoltaics using al nanoparticle modified PC61BM layer. Sol. Energy 2020, 201, 621-627. [CrossRef] 
222. Li, H.; Hu, Y.; Yang, Y.; Zhu, Y. Theoretical investigation of broadband absorption enhancement in a-Si thin-film solar cell with nanoparticles. Sol. Energy Mater. Sol. Cells 2020, 211, 110529. [CrossRef]

223. Subhan, F.E.; Khan, A.D.; Hilal, F.E.; Khan, A.D.; Khan, S.D.; Ullah, R.; Imran, M.; Noman, M. Efficient broadband light absorption in thin-film a-Si solar cell based on double sided hybrid bi-metallic nanogratings. RSC Adv. 2020, 10, 11836-11842. [CrossRef]

224. Gao, B.; Duan, W.; Toor, F. Efficiency Improvement of Planar Silicon Solar Cells Utilizing Localized Surface Plasmon Resonance of Silver Nanoparticles. In Proceedings of the IEEE 46th Photovoltaic Specialists Conference (PVSC), Chicago, IL, USA, 16-21 June 2019; pp. 1887-1891. [CrossRef]

225. Ho, W.-J.; Lin, W.-C.; Liu, J.-J.; Syu, H.-J.; Lin, C.-F. Enhancing the Performance of Textured Silicon Solar Cells by Combining Up-Conversion with Plasmonic Scattering. Energies 2019, 12, 4119. [CrossRef]

226. Khan, A.D.; Rehman, Q.; Khan, A.D.; Subhan, F.E.; Noman, M.; Ahmed, S.; Khan, H.A. Broadband Solar Energy Absorption in Plasmonic Thin-Film Amorphous Silicon Solar Cell. Coatings 2019, 9, 638. [CrossRef]

227. Ho, W.-J.; Chen, G.-Y.; Liu, J.-J. Enhancing Photovoltaic Performance of Plasmonic Silicon Solar Cells with ITO Nanoparticles Dispersed in $\mathrm{SiO} 2$ Anti-Reflective Layer. Materials 2019, 12, 1614. [CrossRef] [PubMed]

228. Koval, V.; Yakvmenko, Y.; Ivashchuk, A.; Dusheyko, M.; Fadieiev, M.; Didichenko, D.; Borodinova, T. Application of Au Nanoparticles for Silicon Heterojunction Solar Cells. In Proceedings of the 2018 IEEE 38th International conference on Electronics and Nanotechnology (ELNANO), Kyiv, Ukraine, 24-26 April 2018; pp. 186-190. [CrossRef]

229. Dhar, S.; Mandal, S.; Mitra, S.; Ghosh, H.; Mukherjee, S.; Banerjee, C.; Saha, H.; Barua, A.K. Light trapping in a-Si/c-Si heterojunction solar cells by embedded ITO nanoparticles at rear surface. J. Phys. D Appl. Phys. 2017, 50, 495110. [CrossRef]

230. Knight, M.W.; van de Groep, J.; Bronsveld, P.C.; Sinke, W.C.; Polman, A. Soft imprinted Ag nanowire hybrid electrodes on silicon heterojunction solar cells. Nano Energy 2016, 30, 398-406. [CrossRef]

231. Parashar, P.K.; Komarala, V.K. Engineered optical properties of silver-aluminum alloy nanoparticles embedded in SiON matrix for maximizing light confinement in plasmonic silicon solar cells. Sci. Rep. 2017, 7, 12520. [CrossRef]

232. Venugopal, N.; Gerasimov, V.; Ershov, A.; Karpov, S.; Polyutov, S. Titanium nitride as light trapping plasmonic material in silicon solar cell. Opt. Mater. 2017, 72, 397-402. [CrossRef]

233. Ho, W.-J.; Lee, Y.-Y.; Lin, C.-H.; Yeh, C.-W. Performance enhancement of plasmonics silicon solar cells using Al2O3/In NPs/TiO2 antireflective surface coating. Appl. Surf. Sci. 2015, 354, 100-105. [CrossRef]

234. Raja, W.; Bozzola, A.; Zilio, P.; Miele, E.; Panaro, S.; Wang, H.; Toma, A.; Alabastri, A.; De Angelis, F.; Zaccaria, R.P. Broadband absorption enhancement in plasmonic nanoshells-based ultrathin microcrystalline-Si solar cells. Sci. Rep. 2016, 6, 24539. [CrossRef]

235. Shokeen, P.; Jain, A.; Kapoor, A. Plasmonic ZnO/p-silicon heterojunction solar cell. Opt. Mater. 2017, 67, 32-37. [CrossRef]

236. Ho, W.-J.; Lee, Y.-Y.; Su, S.-Y. External quantum efficiency response of thin silicon solar cell based on plasmonic scattering of indium and silver nanoparticles. Nanoscale Res. Lett. 2014, 9, 483. [CrossRef] [PubMed]

237. Islam, K.; Alnuaimi, A.; Battal, E.; Okyay, A.K.; Nayfeh, A. Effect of gold nanoparticles size on light scattering for thin film amorphous-silicon solar cells. Sol. Energy 2014, 103, 263-268. [CrossRef]

238. Yu, J.; Shao, W.; Zhou, Y.; Wang, H.; Liu, X.; Xu, X. Nano Ag-enhanced energy conversion efficiency in standard commercial pc-Si solar cells and numerical simulations with finite difference time domain method. Appl. Phys. Lett. 2013, 103, 203904. [CrossRef]

239. Yang, Y.; Pillai, S.; Mehrvarz, H.; Kampwerth, H.; Ho-Baillie, A.; Green, M. Enhanced light trapping for high efficiency crystalline solar cells by the application of rear surface plasmons. Sol. Energy Mater. Sol. Cells 2012, 101, 217-226. [CrossRef]

240. Beck, F.J.; Mokkapati, S.; Polman, A.; Catchpole, K.R. Asymmetry in photocurrent enhancement by plasmonic nanoparticle arrays located on the front or on the rear of solar cells. Appl. Phys. Lett. 2010, 96, 33113. [CrossRef]

241. Fahim, N.F.; Jia, B.; Shi, Z.; Gu, M. Simultaneous broadband light trapping and fill factor enhancement in crystalline silicon solar cells induced by Ag nanoparticles and nanoshells. Opt. Express 2012, 20, A694-A705. [CrossRef]

242. Tong, C.; Yun, J.; Song, H.; Gan, Q.; Anderson, W.A. Plasmonic-enhanced Si Schottky barrier solar cells. Sol. Energy Mater. Sol. Cells 2014, 120, 591-595. [CrossRef]

243. Ramadan, R.; Manso-Silván, M.; Martín-Palma, R.J. Hybrid porous silicon/silver nanostructures for the development of enhanced photovoltaic devices. J. Mater. Sci. 2020, 55, 5458-5470. [CrossRef]

244. Ferry, V.E.; Verschuuren, M.A.; Li, H.B.T.; Schropp, R.E.; Atwater, H.A.; Polman, A. Improved red-response in thin film a-Si:H solar cells with soft-imprinted plasmonic back reflectors. Appl. Phys. Lett. 2009, 95, 183503. [CrossRef]

245. Zhang, D.; Digdaya, I.; Santbergen, R.; van Swaaij, R.; Bronsveld, P.; Zeman, M.; van Roosmalen, J.; Weeber, A. Design and fabrication of a SiOx/ITO double-layer anti-reflective coating for heterojunction silicon solar cells. Sol. Energy Mater. Sol. Cells 2013, 117, 132-138. [CrossRef]

246. Li, X.; Hylton, N.; Giannini, V.; Lee, K.-H.; Ekins-Daukes, N.; Maier, S. Bridging electromagnetic and carrier transport calculations for three-dimensional modelling of plasmonic solar cells. Opt. Express 2011, 19, A888-A896. [CrossRef] [PubMed]

247. Wu, J.; Yu, P.; Susha, A.S.; Sablon, K.A.; Chen, H.; Zhou, Z.; Li, H.; Ji, H.; Niu, X.; Govorov, A.O.; et al. Broadband efficiency enhancement in quantum dot solar cells coupled with multispiked plasmonic nanostars. Nano Energy 2015, 13, 827-835. [CrossRef]

248. Luo, L.-B.; Xie, C.; Wang, X.-H.; Yu, Y.-Q.; Wu, C.-Y.; Hu, H.; Zhou, K.-Y.; Zhang, X.-W.; Jie, J. Surface plasmon resonance enhanced highly efficient planar silicon solar cell. Nano Energy 2014, 9, 112-120. [CrossRef]

249. Farhat, M.; Kais, S.; Alharbi, F. Plasmonically Enhanced Schottky Photovoltaic Devices. Sci. Rep. 2017, 7, 14253. [CrossRef] [PubMed] 
250. He, Z.; Gu, J.H.; Sha, W.E.I.; Chen, R.S. Efficient volumetric method of moments for modeling plasmonic thin-film solar cells with periodic structures. Opt. Express 2018, 26, 25037-25046. [CrossRef] [PubMed]

251. Forestiere, C.; Iadarola, G.; Rubinacci, G.; Tamburrino, A.; Negro, L.D.; Miano, G. Surface integral formulations for the design of plasmonic nanostructures. J. Opt. Soc. Am. A 2012, 29, 2314-2327. [CrossRef]

252. Dewan, R.; Jovanov, V.; Hamraz, S.; Knipp, D. Analyzing periodic and random textured silicon thin film solar cells by Rigorous Coupled Wave Analysis. Sci. Rep. 2014, 4, srep06029. [CrossRef]

253. COMSOL. COMSOL Multiphysics ${ }^{\circledR}$ v. 5.4; COMSOL: Burlington, MA, USA, 2019.

254. Lumerical Inc. Lumerical. Available online: https://www.lumerical.com/products (accessed on 25 January 2021).

255. Michael, S.; Bates, A.; Green, M. Silvaco ATLAS as a Solar Cell Modeling Tool. In Proceedings of the Conference Record of the Thirty-First IEEE Photovoltaic Specialist Conference, Lake Buena Vista, FL, USA, 3-7 January 2005. [CrossRef]

256. Hohenester, U.; Trügler, A. MNPBEM-A Matlab toolbox for the simulation of plasmonic nanoparticles. Comput. Phys. Commun. 2012, 183, 370-381. [CrossRef]

257. Oskooi, A.F.; Roundy, D.; Ibanescu, M.; Bermel, P.; Joannopoulos, J.; Johnson, S.G. Meep: A flexible free-software package for electromagnetic simulations by the FDTD method. Comput. Phys. Commun. 2010, 181, 687-702. [CrossRef]

258. Wiecha, P.R. pyGDM-A python toolkit for full-field electro-dynamical simulations and evolutionary optimization of nanostructures. Comput. Phys. Commun. 2018, 233, 167-192. [CrossRef]

259. Burgelman, M.; Decock, K.; Khelifi, S.; Abass, A. Advanced electrical simulation of thin film solar cells. Thin Solid Films 2013, 535, 296-301. [CrossRef]

260. Liu, F.; Zhu, J.; Wei, J.; Li, Y.; Lv, M.; Yang, S.; Zhang, B.; Yao, J.; Dai, S. Numerical simulation: Toward the design of high-efficiency planar perovskite solar cells. Appl. Phys. Lett. 2014, 104, 253508. [CrossRef]

261. Clugston, D.; Basore, P. PC1D version 5: 32-bit solar cell modeling on personal computers. In Proceedings of the Conference Record of the Twenty Sixth IEEE Photovoltaic Specialists Conference, Anaheim, CA, USA, 29 September-3 October 1997; pp 207-210. [CrossRef]

262. Fell, A. A Free and Fast Three-Dimensional/Two-Dimensional Solar Cell Simulator Featuring Conductive Boundary and Quasi-Neutrality Approximations. IEEE Trans. Electron Devices 2012, 60, 733-738. [CrossRef]

263. Baloch, A.A.B.; Aly, S.P.; Hossain, M.I.; El-Mellouhi, F.; Tabet, N.; Alharbi, F. Full space device optimization for solar cells. Sci. Rep. 2017, 7, 11984. [CrossRef]

264. Malkiel, I.; Mrejen, M.; Nagler, A.; Arieli, U.; Wolf, L.; Suchowski, H. Plasmonic nanostructure design and characterization via Deep Learning. Light. Sci. Appl. 2018, 7, 1-8. [CrossRef]

265. Yao, K.; Unni, R.; Zheng, Y. Intelligent nanophotonics: Merging photonics and artificial intelligence at the nanoscale. Nanophotonics 2019, 8, 339-366. [CrossRef]

266. Jafar-Zanjani, S.; Inampudi, S.; Mosallaei, H. Adaptive Genetic Algorithm for Optical Metasurfaces Design. Sci. Rep. 2018, 8, 1-16. [CrossRef]

267. Gallinet, B.; Butet, J.; Martin, O.J.F. Numerical methods for nanophotonics: Standard problems and future challenges. Laser Photon. Rev. 2015, 9, 577-603. [CrossRef]

268. Aïssa, B.; A El Khakani, M. The channel length effect on the electrical performance of suspended-single-wall-carbon-nanotubebased field effect transistors. Nanotechnology 2009, 20, 175203. [CrossRef]

269. Memmi, H.; Benson, O.; Sadofev, S.; Kalusniak, S. Strong Coupling between Surface Plasmon Polaritons and Molecular Vibrations. Phys. Rev. Lett. 2017, 118, 126802. [CrossRef]

270. Zhou, Y.; Scuri, G.; Wild, D.; High, A.A.; Dibos, A.; Jauregui, L.A.; Shu, C.; De Greve, K.; Pistunova, K.; Joe, A.; et al. Probing dark excitons in atomically thin semiconductors via near-field coupling to surface plasmon polaritons. Nat. Nanotechnol. 2017, 12, 856-860. [CrossRef] [PubMed]

271. Khurgin, J.B. How to face the loss in plasmonics and metamaterials. arXiv 2014, arXiv:1411.6577.

272. Gu, M.; Ouyang, Z.; Jia, B.; Stokes, N.; Chen, X.; Fahim, N.; Li, X.; Ventura, M.J.; Shi, Z. Nanoplasmonics: A frontier of photovoltaic solar cells. Nanophotonics 2012, 1, 235-248. [CrossRef]

273. Campion, A.; Kambhampati, P. Surface-enhanced Raman scattering. Chem. Soc. Rev. 1998, 27, 241-250. [CrossRef]

274. Farhat, M.; Baloch, A.A.B.; Rashkeev, S.N.; Tabet, N.; Kais, S.; Alharbi, F.H. Bifacial Schottky-Junction Plasmonic-Based Solar Cell. Energy Technol. 2020, 8. [CrossRef]

275. Jang, Y.H.; Jang, Y.J.; Kim, S.; Na Quan, L.; Chung, K.; Kim, D.H. Plasmonic Solar Cells: From Rational Design to Mechanism Overview. Chem. Rev. 2016, 116, 14982-15034. [CrossRef]

276. Liu, N.; Tang, M.L.; Hentschel, M.; Giessen, H.; Alivisatos, P. Nanoantenna-enhanced gas sensing in a single tailored nanofocus. Nat. Mater. 2011, 10, 631-636. [CrossRef]

277. Lim, M.; Song, J.; Lee, S.S.; Lee, B.J. Tailoring near-field thermal radiation between metallo-dielectric multilayers using coupled surface plasmon polaritons. Nat. Commun. 2018, 9, 1-9. [CrossRef]

278. Whang, S.-J.; Lee, S.; Chi, D.-Z.; Yang, W.-F.; Cho, B.-J.; Liew, Y.-F.; Kwong, D.-L. B-doping of vapour-liquid-solid grown Au-catalysed and Al-catalysed Si nanowires: Effects of B2H6gas during Si nanowire growth and B-doping by a post-synthesisin situplasma process. Nanotechnology 2007, 18. [CrossRef]

279. de Abajo, F.J.G.; Kociak, M. Probing the Photonic Local Density of States with Electron Energy Loss Spectroscopy. Phys. Rev. Lett. 2008, 100, 106804. [CrossRef] 